\title{
$1115^{\circ}$
}

SOEP papers

on Multidisciplinary Panel Data Research

\section{First Time Around: Local Conditions and Multi-dimensional Integration of Refugees}


This series presents research findings based either directly on data from the German SocioEconomic Panel (SOEP) or using SOEP data as part of an internationally comparable data set (e.g. CNEF, ECHP, LIS, LWS, CHER/PACO). SOEP is a truly multidisciplinary household panel study covering a wide range of social and behavioral sciences: economics, sociology, psychology, survey methodology, econometrics and applied statistics, educational science, political science, public health, behavioral genetics, demography, geography, and sport science.

The decision to publish a submission in SOEPpapers is made by a board of editors chosen by the DIW Berlin to represent the wide range of disciplines covered by SOEP. There is no external referee process and papers are either accepted or rejected without revision. Papers appear in this series as works in progress and may also appear elsewhere. They often represent preliminary studies and are circulated to encourage discussion. Citation of such a paper should account for its provisional character. A revised version may be requested from the author directly.

Any opinions expressed in this series are those of the author(s) and not those of DIW Berlin. Research disseminated by DIW Berlin may include views on public policy issues, but the institute itself takes no institutional policy positions.

The SOEPpapers are available at http://www.diw.de/soeppapers

\section{Editors:}

Jan Goebel (Spatial Economics)

Stefan Liebig (Sociology)

David Richter (Psychology)

Carsten Schröder (Public Economics)

Jürgen Schupp (Sociology)

Sabine Zinn (Statistics)

Conchita D'Ambrosio (Public Economics, DIW Research Fellow)

Denis Gerstorf (Psychology, DIW Research Fellow)

Katharina Wrohlich (Gender Economics)

Martin Kroh (Political Science, Survey Methodology)

Jörg-Peter Schräpler (Survey Methodology, DIW Research Fellow)

Thomas Siedler (Empirical Economics, DIW Research Fellow)

C. Katharina Spieß (Education and Family Economics)

Gert G. Wagner (Social Sciences)

ISSN: 1864-6689 (online)

German Socio-Economic Panel (SOEP)

DIW Berlin

Mohrenstrasse 58

10117 Berlin, Germany

Contact: soeppapers@diw.de

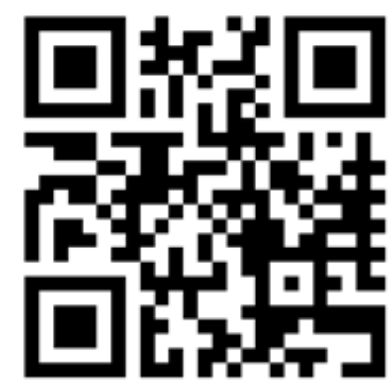




\title{
First Time Around:
}

\section{Local Conditions and Multi-dimensional Integration of Refugees ${ }^{\mathrm{a}}$}

\author{
Cevat Giray Aksoy ${ }^{\mathrm{b}} \quad$ Panu Poutvaarac ${ }^{\mathrm{c}} \quad$ Felicitas Schikora $^{\mathrm{d}}$
}

December 14, 2020

\begin{abstract}
We study the causal effect of local labor market conditions and attitudes towards immigrants at the time of arrival on refugees' multi-dimensional integration outcomes (economic, linguistic, navigational, political, psychological, and social). Using a unique dataset on refugees, we leverage a centralized allocation policy in Germany where refugees were exogenously assigned to live in specific counties. We find that high initial local unemployment negatively affects refugees' economic and social integration: they are less likely to be in education or employment and they earn less. We also show that favorable attitudes towards immigrants promote refugees' economic and social integration. The results suggest that attitudes toward immigrants are as important as local unemployment rates in shaping refugees' integration outcomes. Using a machine learning classifier algorithm, we find that our results are driven by older people and those with secondary or tertiary education. Our findings highlight the importance of both initial economic and social conditions for facilitating refugee integration, and have implications for the design of centralized allocation policies.
\end{abstract}

Keywords: International migration, refugees, integration, allocation policy.

JEL codes: F22, J15, J24.

\footnotetext{
${ }^{a}$ We thank Patrick Burauel, Ralph De Haas, Katia Gallegos, Yvonne Giesing, Martin Lange, Nadzeya Laurentsyeva, Karen Macours, Seyhun Orcan Sakalli, Katrin Sommerfeld, and participants at the Jahrestagung Verein für Socialpolitik, the CEMIR Junior Economist Workshop on Migration Research, and ZEW Research Seminar for their valuable feedback. Views presented are those of the authors and not necessarily of the European Bank for Reconstruction and Development (EBRD) or any other organization. All interpretations, errors, and omissions are our own.

${ }^{\mathrm{b}}$ Cevat Giray Aksoy is a Principal Economist at the EBRD, Assistant Professor of Economics at King's College London, and Research Associate at IZA Institute of Labor Economics, aksoyc@ebrd.com.

${ }^{\mathrm{c}}$ Panu Poutvaara is a Professor of Economics at the University of Munich, Director of the ifo Center for International Institutional Comparisons and Migration Research at the ifo Institute and Research Fellow at CESifo, CReAM, and IZA Institute of Labor Economics, poutvaara@ifo.de.

dFelicitas Schikora is a PhD candidate at Freie Universität Berlin and DIW Berlin, fschikora@diw.de.
} 


\section{Introduction}

Refugees typically arrive in a host country with worse language skills and less locally applicable human capital than economic migrants, and consequently are likely to start at significantly lower levels of wages and employability (Brell et al. 2020). Therefore, refugees are often among the most vulnerable immigrant groups, facing the steepest barriers to economic and social integration (Martén et al. 2019). At the same time, initial conditions at the time of arrival matter for successful integration and have been shown to have long-lasting effects for refugees and economic migrants (Chiswick and Miller (1999), Åslund and Rooth (2007), Barsbai et al. (2019)).

In this paper, we provide the first systematic evidence on how initial local unemployment shapes the multi-dimensional integration of refugees in the context of the European refugee crisis. We focus on refugees who arrived in Germany between 2013 and 2016 and have been subsequently interviewed in the IAB-BAMFSOEP Survey of Refugees, the largest representative survey of refugees in Europe. Refugees are eligible to enter the German labor market three months after submitting their asylum request. ${ }^{1}$ Our identification relies on the exogenous placement of refugees upon arrival across counties and the fact that they cannot freely choose their place of residence for a period of at least three years. This settlement policy provides an almost ideal exogenous variation to study the causal effect of initial local conditions on refugees' integration, and is one of the factors that differentiates our work from previous studies. ${ }^{2}$

A further distinguishing feature of our work is the fact that we consider attitudes towards immigrants ${ }^{3}$, which have not previously received much attention in the literature, as an important factor in shaping refugees' integration. ${ }^{4}$ This lack of focus is surprising since attitudes towards immigrants are being recognized as an important driver of public policy (Facchini and Mayda 1999; Matakos et al. 2020) and recent literature shows that immigration also increases anti-migrant sentiment and support for far-right parties (see, for example, Otto and Steinhardt (2014), Edo et al. (2019), Hangartner et al. (2019), and Ajzenman et al. (2020)). Moreover, we focus on multi-dimensional (economic, linguistic, navigational, political, psychological, and social) integration of refugees as opposed to simply economic integration. This is important as far less attention has been devoted to non-economic outcomes, despite the fact that they are crucial for encouraging

\footnotetext{
${ }^{1}$ See Section 2 for detailed information about the institutional setting and refugees' access to education and labor market.

${ }^{2}$ An important exception is Martén et al. (2019).

${ }^{3}$ It is important to emphasize early on that local attitudes towards immigrants do not co-move with unemployment: the correlation between the migrant acceptance index and unemployment rate is very weak (-0.19). See Section 4 for more details on the identification strategy.

${ }^{4}$ There are two related experimental studies. Bansak et al. (2016) conducted a conjoint experiment in which voters in 15 European countries were asked to evaluate hypothetical asylum seekers that randomly varied on nine attributes. They found that applications by asylum seekers who have better employment potential and more credible claim for asylum are more likely to be supported, while applications by Muslims receive lower support, ceteris paribus. In a related study, Getmansky et al. (2020) field a conjoint survey experiment in Turkey to examine whether Turkish citizens reduce anti-refugee attitudes if they know that Syrian refugees have made proactive effort to integrate by forging social ties with the locals and learning the local language. They find a significant bias against Arabs and Kurds compared to Turkomans, and against former pro-regime fighters.
} 
a sense of belonging in the host country. We fill these gaps in our paper.

Our main findings are twofold. First, we find that refugees assigned to counties with high unemployment rates are less likely to be in employment or education and less likely to be in full- or part-time employment. Furthermore, poor initial labor market conditions have a strong negative impact on refugees' net monthly earnings and the Multi-dimensional Integration Index. Second, we find that favorable attitudes towards immigrants positively affect refugees' labor market outcomes and their economic and social integration. Together, these findings help us to understand how conditions at the time of arrival affect refugees' integration. They also have implications for the design of refugee allocation policies, as gains made in the first few years have long-lasting effects. In terms of fiscal cost, our back-of-the-envelope calculations suggest that allocating 10,000 randomly selected working-age refugees to a county with a one standard deviation lower unemployment rate would generate an annual saving of more than $€ 2$ million.

To look beyond average effects, we use a machine learning classifier algorithm (in this case, causal forest) and investigate treatment heterogeneity. We find that our results are driven by older people and those with secondary or tertiary education. We also conduct several additional robustness checks and address potential concerns about omitted variable bias (following Oster (2019)) as well as multiple hypothesis testing (following Young (2019)).

Our paper is closely related to a handful of studies that have examined the effect of initial conditions on refugees' integration outcomes. Among those, two recent studies focused on the impact of employment bans that prevent asylum seekers from entering the local labor market upon arrival. Fasani et al. (2020a) show that exposure to a ban at arrival reduces refugee employment probability in subsequent years by about 15 percent, an impact driven primarily by lower labor market participation. Marbach et al. (2018) leverage a natural experiment in Germany, where a court ruling prompted a reduction in the length of the employment ban. They find that longer employment bans considerably slowed down the economic integration of refugees. To the best of our knowledge, only three papers have explored the effect of local initial conditions, all of which focused only on refugees' economic integration. Martén et al. (2019) study the role of ethnic networks on refugee integration by leveraging the allocation policy in Switzerland, where some refugees are assigned to live in a specific location upon arrival and are not permitted to relocate during the first five years. They find that refugees assigned to locations with many co-nationals are more likely to enter the labor market. Åslund and Rooth (2007) examine the long-term effects of labor market conditions encountered upon arrival in Sweden on immigrant earnings and employment. They find that early earnings assimilation depends crucially on a favorable national labor market. Exposure to high local unemployment rates also affects individuals for a decade. Godøy (2017) studies a subset of refugees in Norway, who are subject to a quasi-experimental settlement policy. She finds that assigning refugees to regions with good non-OECD immigrant labor markets 
increases their later labor market earnings. We complement these studies by providing new evidence on the short-term integration outcomes for refugees using a representative sample from Germany.

We also contribute to the growing literature on the social integration of refugees. Ager and Strang (2008) develop a conceptual framework that specifies ten core factors (ranging from housing, education, and health to social connection in the community) that affect refugee integration. Harder et al. (2018) also propose a survey-based measure that identifies six dimensions (psychological, economic, political, social, linguistic, and navigational) of immigrant integration. In this paper, we use the definitions provided by Harder et al. (2018) and formally test how initial local conditions shape the various integration dimensions. ${ }^{5}$

Our paper is related to the literature on the factors that affect refugees' labor market integration. ${ }^{6}$ Several studies (see, for example, Edin et al. (2003), Damm (2009), and Beaman (2012)) have found that living in regions with high concentrations of co-ethnic individuals can improve refugees' labor market outcomes. Arendt et al. (2020) analyze the impact of an expansion of language training for refugees in Denmark. They show that, after eighteen years refugees who received more and better language training were more likely to be in employment and had higher earnings. Furthermore, children of refugees who received enhanced language classes were more likely to complete lower secondary school and less likely to commit crime. Battisti et al. (2019) conduct a field experiment to evaluate the impact of job search assistance on the employment of recently arrived refugees in Germany. They find that personalized job search assistance can improve labor market integration of refugees.

Finally, there is a growing body of work on how refugees' labor market outcomes compare to those of other migrant groups and natives in high-income host countries. Brell et al. (2020) provide a comprehensive review of refugees' economic integration in several OECD countries and find that refugees have substantially lower employment rates than other immigrants, for at least the first decade after arrival. Those refugees who do find work also receive much lower wages than other immigrants. ${ }^{7}$ Similarly, using data from 19 European countries, Fasani et al. (2020b) document that labor market outcomes for refugees are consistently worse than those for other comparable migrants. Using data from Germany, Brücker et al. (2020) show that 50 percent of the refugees have a job after five years. Although the labor market integration of refugees is making slower progress than that of economic migrants in Germany, refugees who have arrived since 2013 fare better than previous refugee cohorts. We find that among refugees aged 18 to 49,54 percent of men and

\footnotetext{
${ }^{5}$ Braun and Dwenger (2020) show that settlement location strongly affected the economic and social integration of millions of Germans who were expelled from Eastern Europe into West Germany after the Second World War, with integration proceeding worse in agrarian regions and in regions with high inflows of migrants. Bauer et al. (2013) show that in 1971, expellees still fared worse economically than other Germans.

${ }^{6}$ For more comprehensive review of this literature, see Strang and Ager (2010) and Becker and Ferrara (2019).

${ }^{7}$ Bratsberg et al. (2017), Sarvimäki (2017), Schultz-Nielsen (2017), and Joyce (2019) find that persistent employment gaps between refugees and economic migrants or natives remain in Scandinavian countries. In the UK, employment and work hour gaps between asylum seekers and other migrants take more than 25 years of residence in the country to close, but earnings and salary gaps persist (Ruiz and Vargas-Silva 2018).
} 
17 percent of women who have been in Germany five years are in employment or education. Refugees' low labor force participation constitutes a major loss both to refugees themselves and to the receiving country. What makes it even more striking is that refugees who arrived in Germany are positively self-selected with respect to human capital (Aksoy and Poutvaara 2019).

It is also important to highlight that we analyze the integration process of refugees at an early stage. About 85 percent of refugees in our study have been in Germany for three years or less at the time of the interview, with some 15 percent having stayed four or five years. This means that current employment rates are lower than those expected in a few years' time. Yet, having information on the short-term integration outcomes provides important insights on how well or poorly the integration process is progressing. From the policy perspective, obtaining such early insights is more valuable than waiting until the integration process has run its course in order to help the large number of refugees who have arrived in Germany in the meantime. Furthermore, comparing early outcomes for men and women, for refugees from various origin countries, and refugees with differing levels of education provides valuable insights on which groups face the most severe challenges. Finally, our results can be informative for designing integration policies for other refugee-hosting countries.

The remainder of the paper is organized as follows: Section 2 provides information on institutional background and exogenous placement of refugees. Section 3 provides details on the data sources and descriptive statistics. Section 4 describes the empirical strategy. Section 5 presents the results, after which section 6 concludes.

\section{Institutional Background}

\subsection{Refugee Settlement Policy and Exogenous Placement}

The distribution of refugees across Germany follows an established process including a pre-defined allocation scheme, the Königstein Key. Each refugee is registered upon arrival and subsequently assigned to an initial reception center in one of Germany's 16 federal states, where the refugee may formally apply for political asylum. $^{8}$

The Königstein Key determines what share of asylum seekers is received by each state based on the states' tax revenues (accounting for $2 / 3$ of the quota) and population sizes (accounting for $1 / 3$ of the quota), which are calculated on an annual basis. ${ }^{9}$ This mechanism ensures a proportional distribution of asylum seekers

\footnotetext{
${ }^{8}$ Asylum seekers can be accommodated in reception facilities for up to six months, or until their application is decided on. They can, however, also be allocated to another facility during this period under certain circumstances, for instance for family reunification.

${ }^{9}$ In case there are several reception centers within the assigned state, the EASY (Initial Distribution of Asylum Seekers) quota system chooses the reception center located nearest to the authority where the registration took place in order to minimize
} 
across states. Appendix Table A1 illustrates the states' received versus assigned share of asylum seekers based on the Königstein Key between 2013 and 2018. The reported shares suggest that the distribution of asylum seekers has been mostly in line with the quotas (i.e. Königstein Key). Small deviations from the quota can be explained by the fact that the distribution of applicants takes into account additional criteria (such as health-care related reasons and family reunification).

Since many refugees are likely to stay in Germany for a long time, the federal government passed the Integration Act in July 2016. This law severely restricts refugees' ability to choose their place of residence. Unless legal exemption criteria apply, refugees with a temporary or permanent residence permit are obliged to stay in their initial county of residence for at least three years. ${ }^{10}$ Therefore, mobility across counties is severely restricted for the vast majority of refugees in Germany. This minimizes concerns related to the endogenous residential sorting of refugees when analyzing the effects of initial local conditions. The settlement policy also addresses two important potential sources of bias: (i) it is mandatory for states and counties to participate in the allocation program; (ii) it is also mandatory for refugees to participate in the allocation program.

All three features (exogenous allocation, mobility restriction, and mandatory participation) of the settlement policy are crucial for our identification strategy as they generate a random allocation of refugees to counties. In other words, we rely on a quasi-natural experiment of exogenous allocation of refugees to identify the causal effect of initial local conditions on their multi-dimensional integration outcomes.

\subsection{Access to Education and the Labor Market}

Schooling is compulsory for all children in Germany and children's right to education is protected by the United Nations (Massumi et al. 2015). This implies that children who have arrived in Germany as asylum seekers have to attend school after three to six months, irrespective of their type of residence permit. Adult refugees' right to education, on the other hand, is expressed in the Geneva Refugee Convention, whereby refugees should be treated as favorably as possible, and in any event, not less favorably than foreigners in the same circumstances. ${ }^{11}$

Refugees' access to the German labor market has been greatly facilitated in recent years (Sachverständi-

commuting costs. Within each state, asylum seekers are allocated to a particular municipality, usually the place of the initial reception center at first and possibly another municipality when the obligation to live in the initial reception center ends. For further information, please see https://www.asylumineurope.org/reports/country/germany/overview-legal-framework, last accessed on November 24, 2020.

${ }^{10}$ Exemptions apply, for instance, if the refugee or a close relative (spouse, domestic partner, or child) attends university/vocational training or has taken up employment with a certain number of working hours. For further information, see the Federal Ministry of Justice and Consumer Protection, 2016, Residence Act (Aufenthaltsgesetz) Section 12a, Art. 1. Considering that the vast majority of refugees are still not in employment or education (Table 2), residence restrictions are still widely common for refugees in Germany.

${ }^{11}$ See UNHCR, Convention Relating to the Status of Refugees of 28 July 1951, Article 22 (1951) (available online). 
genrat deutscher Stiftungen für Integration und Migration 2017). In 2014, the employment ban for asylum seekers was reduced from nine to three months, so that asylum seekers are generally eligible to enter the German labor market three months after submitting their asylum request. ${ }^{12}$ This excludes asylum seekers from Germany's list of "safe countries" (that is, all EU member states, Albania, Bosnia-Herzegovina, Ghana, Kosovo, Montenegro, North Macedonia, Senegal, and Serbia), who are very unlikely to be granted a permanent residence permit. The "priority check" also has been abolished. With the "priority check" in place, asylum seekers in Germany could take up employment only if the Federal Employment Agency concluded that there was no German or EU citizen who would be available for that specific job. Refugees with a permanent residence permit have unrestricted access to the German labor market.

\subsection{Cross-state Variation in Germany}

Germany adopted a federal system after the Second World War and individual states have legislative and executive powers in many important policy areas, including education. This causes large variations in policies across German states. Furthermore, states differ in their demographic and industrial structure and in their income levels. The differences are especially pronounced between eastern and western German states, still reflecting differences from before the German reunification in 1989. On average, eastern German states are less densely populated, their populations tend to be older, and they have lower per capita income.

These structural differences may go together with variations in preferences and values. To compare differences in attitudes and values across German states, we rely on information from the European Social Survey (ESS), a cross-sectional, nationally representative attitudinal survey.

Table 1 provides descriptive evidence on preferences and values for Germany as a whole (column 1), western German states (column 2), and eastern German states (column 3). The table illustrates the large cross-state variation in attitudes towards migrants, trust, and various satisfaction measures: people in western German states are more likely to be in favor of immigration, more likely to trust people and institutions, and more likely to be satisfied with life. Overall, we make sure that our empirical strategy accounts for systemic differences across states.

\footnotetext{
${ }^{12}$ The period is extended to six months for asylum seekers with minor children and nine months for asylum seekers who are required to live in an initial reception center (https://www.bmas.de/DE/Themen/Arbeitsmarkt/Infos-fuer-Asylsuchende/ arbeitsmarktzugang-asylbewerber-geduldete.html), last accessed 09.09.2020.
} 
Table 1: Attitudinal differences across Germany

\begin{tabular}{|c|c|c|c|}
\hline & $\begin{array}{c}(1) \\
\text { Full sample } \\
\text { mean/sd }\end{array}$ & $\begin{array}{c}(2) \\
\text { West Germany } \\
\text { mean/sd }\end{array}$ & $\begin{array}{c}(3) \\
\text { East Germany } \\
\text { mean/sd }\end{array}$ \\
\hline Allow immigration from ethnic majority & $\begin{array}{c}0.285 \\
(0.887)\end{array}$ & $\begin{array}{c}0.385 \\
(0.812)\end{array}$ & $\begin{array}{c}0.096 \\
(0.986)\end{array}$ \\
\hline Allow immigration from ethnic minority & $\begin{array}{c}0.271 \\
(0.942)\end{array}$ & $\begin{array}{c}0.397 \\
(0.888)\end{array}$ & $\begin{array}{c}0.033 \\
(0.994)\end{array}$ \\
\hline Allow immigration from poorer countries & $\begin{array}{c}0.143 \\
(0.992)\end{array}$ & $\begin{array}{c}0.265 \\
(0.953)\end{array}$ & $\begin{array}{l}-0.089 \\
(1.022)\end{array}$ \\
\hline Immigrants put more in than they take out & $\begin{array}{c}0.246 \\
(0.966)\end{array}$ & $\begin{array}{c}0.352 \\
(0.894)\end{array}$ & $\begin{array}{c}0.042 \\
(1.063)\end{array}$ \\
\hline Immigrants do not worsen crime problems & $\begin{array}{c}0.163 \\
(0.977)\end{array}$ & $\begin{array}{c}0.233 \\
(0.915)\end{array}$ & $\begin{array}{c}0.028 \\
(1.073)\end{array}$ \\
\hline Immigration good for cultural life & $\begin{array}{c}0.094 \\
(0.982)\end{array}$ & $\begin{array}{c}0.176 \\
(0.929)\end{array}$ & $\begin{array}{c}-0.062 \\
(1.060)\end{array}$ \\
\hline Immigrants make Germany a better place to live & $\begin{array}{c}0.143 \\
(1.013)\end{array}$ & $\begin{array}{c}0.241 \\
(0.940)\end{array}$ & $\begin{array}{c}-0.043 \\
(1.116)\end{array}$ \\
\hline Immigration good for economy & $\begin{array}{c}0.179 \\
(0.966)\end{array}$ & $\begin{array}{c}0.269 \\
(0.919)\end{array}$ & $\begin{array}{c}0.008 \\
(1.029)\end{array}$ \\
\hline Trust in people & $\begin{array}{c}0.081 \\
(0.949)\end{array}$ & $\begin{array}{c}0.153 \\
(0.912)\end{array}$ & $\begin{array}{l}-0.056 \\
(1.002)\end{array}$ \\
\hline Trust in legal system & $\begin{array}{c}0.016 \\
(1.007)\end{array}$ & $\begin{array}{c}0.142 \\
(0.955)\end{array}$ & $\begin{array}{l}-0.223 \\
(1.059)\end{array}$ \\
\hline Trust in politicians & $\begin{array}{c}0.122 \\
(1.003)\end{array}$ & $\begin{array}{c}0.213 \\
(0.966)\end{array}$ & $\begin{array}{c}-0.051 \\
(1.049)\end{array}$ \\
\hline Trust in parties & $\begin{array}{c}0.132 \\
(1.000)\end{array}$ & $\begin{array}{c}0.222 \\
(0.972)\end{array}$ & $\begin{array}{l}-0.039 \\
(1.029)\end{array}$ \\
\hline Trust in European Parliament & $\begin{array}{c}-0.097 \\
(1.029)\end{array}$ & $\begin{array}{c}-0.017 \\
(1.009)\end{array}$ & $\begin{array}{c}-0.251 \\
(1.050)\end{array}$ \\
\hline Satisfaction with life & $\begin{array}{c}0.133 \\
(0.929)\end{array}$ & $\begin{array}{c}0.237 \\
(0.873)\end{array}$ & $\begin{array}{l}-0.065 \\
(0.998)\end{array}$ \\
\hline Satisfaction with economy & $\begin{array}{c}0.474 \\
(0.840)\end{array}$ & $\begin{array}{c}0.563 \\
(0.802)\end{array}$ & $\begin{array}{c}0.305 \\
(0.884)\end{array}$ \\
\hline Satisfaction with government & $\begin{array}{c}0.384 \\
(0.954)\end{array}$ & $\begin{array}{c}0.496 \\
(0.899)\end{array}$ & $\begin{array}{c}0.171 \\
(1.017)\end{array}$ \\
\hline Satisfaction with democracy & $\begin{array}{c}0.150 \\
(0.978)\end{array}$ & $\begin{array}{c}0.324 \\
(0.915)\end{array}$ & $\begin{array}{c}-0.182 \\
(1.006)\end{array}$ \\
\hline$N$ & 3045 & 1993 & 1052 \\
\hline
\end{tabular}

Note: Means (standard deviations). Berlin is assigned to Eastern Germany. Questions in favor of immigration (the first three questions in the table above) are measured on a 4-point likert scale from 1 "Allow many" to 4 "Allow few". Preferences on immigration are measured on an 11-point likert scale from 0 "bad" to 10 "good". Questions on trust are measured on an 11point likert scale from 0 "you can't be to careful" to 10 "most people can be trusted". Questions on satisfaction are measured on an 11-point likert scale from 0 "extremely dissatisfied" to 10 "extremely satisfied". For consistency reasons, the scale is reversed in "allow immigration" questions, so that higher values indicate more favorable attitudes towards immigrants. All variables are standardized with mean zero and standard deviation one. Source: European Social Survey (2014). 


\section{Data}

\subsection{IAB-BAMF-SOEP Survey of Refugees}

We obtain information on refugees' demographic characteristics and labor market outcomes in Germany from the IAB-BAMF-SOEP Survey of Refugees (the Survey), an annual survey focusing on migrants who are seeking protection from political persecution, war, and conflicts (Brücker et al. (2016) and DIW (2017)). The Survey is collected as part of the German Socio-Economic Panel (SOEP, see Goebel et al. (2019)) and has been carried out on an annual basis since 2016. It is representative of the nationalities and demographic characteristics of refugees who arrived in Germany from 2013 to 2016. The surveys are conducted in different languages and gather information from refugees aged 18 and older.

The Survey provides information on refugees' location of residence histories, socio-demographic characteristics and integration outcomes in Germany. The first wave, conducted in 2016, covers 4,465 adult refugees in Germany. The add-on samples added 2,965 observations in the subsequent survey years. The total sample covers 7,430 adult refugees, who have been part of the Survey at least once. We use the latest survey wave available (that is, v35, 2018) and pool information on all three waves. ${ }^{13}$

The Survey is well-suited for our identification strategy as it provides information on refugees' residency at the time of interview and their initial place of residence. ${ }^{14}$ This information allows us to exploit the exogenous assignment of refugees across German counties. In particular, we define our estimation sample as follows: (i) we drop respondents who do not provide information on their county of first residence; (ii) we then further limit the sample to refugees whose initial interview was during their first two years of residence in Germany. By doing so, we ensure that our sample only includes refugees who are exogenously allocated to counties and have not sorted themselves into another county for socio-economic reasons (see Section 2.1); (iii) we focus on young adults aged 18 to 49 (making up 91 percent of the refugee population) since this age group is much more likely be active in terms of participation in the workforce or being in education. In our final sample, we study about 3,000 refugees aged 18 to 49 who have spent at least two years in Germany.

Figures A1 and A2 show the distribution of refugees across the 401 German counties, for all refugees and refugees from main source countries, based on the Survey and administrative data from Destatis, respectively. As the number of refugees per state increases with tax revenues and population size, it is not surprising that western German states receive, on average, higher shares of refugees (Figure A2). A comparison with

\footnotetext{
${ }^{13}$ Two thirds of the sample were interviewed in 2018 (62 percent). 22 percent of the refugees were last interviewed in 2017 and the remainder of refugees provided information only in the first survey wave in 2016.

${ }^{14}$ In their first SOEP interview, refugees are asked: "Now, please think of the accommodation in which you were housed the longest in Germany before your current accommodation. Where was this accommodation?" While information on the longest place of residence in the first interview should coincide with refugees' first place of residence in most cases, measurement error increases with numbers of years in Germany. To circumvent this limitation, we limit the sample to refugees who gave their first SOEP interview in the first two years of residence in Germany.
} 
Figure A3 shows that these are the states with lower levels of unemployment. Yet, the figures emphasize that all German states have received refugees from the main source countries: Syria, Afghanistan, and Iraq. Furthermore, these figures illustrate that the SOEP successfully sampled refugees throughout Germany and that refugees' allocation resembles administrative numbers to a great extent. There are 38 NUTS-2 subregions and 401 counties (also known as districts) in Germany. Our representative sample consists of refugees from 259 German counties (about two-thirds of German counties). On average, we observe 60 refugees per county and the median equals 40 refugees.

\subsection{Multi-dimensional Integration Index}

We broadly follow the framework outlined in Harder et al. (2018) to build a Multi-dimensional Integration Index. In particular, Harder et al. (2018) identify six crucial dimensions of integration: psychological, economic, political, social, linguistic, and navigational. The index aims to measure the degree to which immigrants have the knowledge and capacity to build a successful life in the host society and has two main components: (i) knowledge, which includes factors such as proficiency in the host country's language and ability to navigate the host country's labor market, political system, and social institutions; and (ii) capacity, which refers to the mental, social, and economic resources immigrants have to invest in their futures. ${ }^{15}$

Based on the questions and definitions proposed in Harder et al. (2018), we construct a Multi-dimensional Integration Index, which consists of 12 survey questions scaled from 1 to 5 . The final index scores are calculated at the individual record level by taking the sum of responses and diving it by 12 . We then rescale it to range from 0 to 1 , with higher values indicating better integration.

In addition, we calculate six sub-indices for each dimension of integration. The respective dimensions are constructed using the following survey items:

1. Psychological integration (aims to capture respondents' feeling of connection with the host country): do you feel welcome in Germany? (1 not at all, 5 totally); how often do you feel like an outsider? (1 very often, 5 never);

2. Economic dimension (aims to capture respondents' economic activity in the host country): what were your gross net earnings last month? (1 lowest quintile, 5 highest quintile); information on work status (1 unemployed, 3 in education or training, 5 in paid work);

3. Political integration (aims to capture understanding of the political issues in the host country): do you think the following things should happen in a democracy or not? The people choose their government

\footnotetext{
${ }^{15}$ See Harder et al. (2018) for a greater detail of the methodology.
} 
in free elections (1 should definitely not happen, 5 should definitely happen); civil rights protect the people from government oppression (1 should definitely not happen, 5 should definitely happen);

4. Social integration (aims to capture social ties and interactions with natives and non-natives in the host country): how often do you spend time with German people (1 never, 5 every day); how often do you spend time with people from other countries (1 never, 5 every day);

5. Linguistic integration (aims to capture respondents' assessment of their ability to read and speak the language of their host country): how well can you speak German (1 not at all, 5 very well); how well can you read German (1 not at all, 5 very well);

6. Navigational integration (aims to capture respondents' ability to manage basic needs in the host country): have you received help to look for employment (1 no, 5 yes); did you receive help to look for health care (1 no, 5 yes);

\subsection{County level Variables}

Administrative data on additional county-level characteristics come from the German Federal Statistical Office (Destatis). We use the share of foreigners of Syrian origin, Afghan origin, and Iraqi origin in refugees' county of residence (as a proxy for pre-existing migrant networks) at the county level from 2014-before refugees started arriving in large numbers in Germany. We use two-year lagged county-level unemployment rate as a proxy for local economic conditions.

Figure A3 illustrates unemployment patterns among counties. A couple of patterns emerge: (i) unemployment rate varies substantially across counties; (ii) unemployment rates tend to be higher in eastern Germany, and generally lower in Baden-Wurttemberg and Bavaria.

\subsection{Migrant Acceptance Index from European Social Survey}

We use European Social Surveys (ESS) conducted in Germany in 2014 to construct our Migrant Acceptance Index (MAI). The ESS sample includes roughly 3,000 respondents aged 18 and older from all 16 states.

The index variables we use come from questions asked to all ESS respondents in an ad-hoc migration module: (i) to what extent do you think Germany should allow people of the same race or ethnic group as most German people to come and live here?; (ii) how about people of a different race or ethnic group from most German people?; (iii) how about people from the poorer countries outside Europe?; (iv) would you say that Germany's cultural life is generally undermined or enriched by people coming to live here from other countries?; (v) is Germany made a worse or a better place to live by people coming to live here from other 
countries?; (vi) would you say it is generally bad or good for Germany's economy that people come to live here from other countries?; (vii) are Germany's crime problems made worse or better by people coming to live here from other countries?; (viii) do you think people who come here take out more than they put in or put in more than they take out? For questions (i), (ii) and (iii), responses were coded on a 4-point scale, ranging from "allow many to come and live here" to "allow none". For questions (iv) to (viii), responses were coded on a 11-point scale, ranging from 0 "negative attitudes towards immigrants" to 10 "positive attitudes towards immigrants". Using principle component analysis (PCA), we construct the MAI, in which the higher index score reflects more favorable attitudes toward immigration. The MAI is standardized (with mean zero and standard deviation one) and ranges from -1 to 1 . Higher values indicate more positive attitudes toward migrants. Figure A4 plots the eigenvalues of principal components used in the PCA.

Figure 1 provides a visual summary of the index at the state level. Attitudes towards migrants are most favorable (that is, the MAI is highest), in the three city states (Berlin, Bremen, and Hamburg) and in the northernmost state Schleswig Holstein, followed by other western German states. The index has lowest values in the former East Germany, outside of Berlin. The Migrant Acceptance Index is therefore in line with recent media coverage, which suggests that attitudes towards immigrants are less favorable in eastern Germany. ${ }^{16}$ Furthermore, several studies have shown that migrants and refugees are more likely to experience xenophobic violence in eastern German states (Entorf and Lange 2019; Falk et al. 2011; Graeber and Schikora 2020; Krueger and Pischke 1997). Throughout the analysis, we include the MAI as one of our main variables of interest as attitudes towards refugees in their initial place of residence are likely to affect their integration outcomes.

\section{Evidence that the Migrant Acceptance Index conveys meaningful information}

An issue that is key to the interpretation is whether our Migrant Acceptance Index conveys meaningful information. To provide evidence on this, we check the correlation between the MAI and four alternative measures: (i) the Gallup Diversity Index (see Section 3.5); (ii) the share of respondents who reported some worries about immigration in 2014:17 (iii) the share of respondents who reported big worries about immigration in 2014; and (iv) the vote share of the right-wing populist party "Alternative für Deutschland (AfD)" in the federal elections in 2013.

We present this evidence in Figure A5, which confirms that the alternative measures we identify are

\footnotetext{
${ }^{16}$ For instance, see https://www.latimes.com/world/la-fg-east-west-germany-refugees-20180917-story.html or https: //www.spiegel.de/international/germany/xenophobia-in-eastern-germany-a-legacy-from-the-past-a-1115163.html, last downloaded on 16.09.2020.

${ }^{17}$ Information on worries about immigration come from the SOEP, where respondents are asked on worries about immigration each year. The question states "How is it with the following topic - immigration to Germany - do you have worries about that?" [1 "Big worries", 2 "Some worries", 3 "No worries"]. Following Poutvaara and Steinhardt (2018), we restrict the sample to German natives aged 18-64. We define an indicator "big worries" equals 1 if respondents state to have big worries, zero otherwise. The indicator "some worries" takes a value of 1 if respondents state to have at least some worries about immigration, zero otherwise.
} 
Figure 1: Migrant Acceptance Index

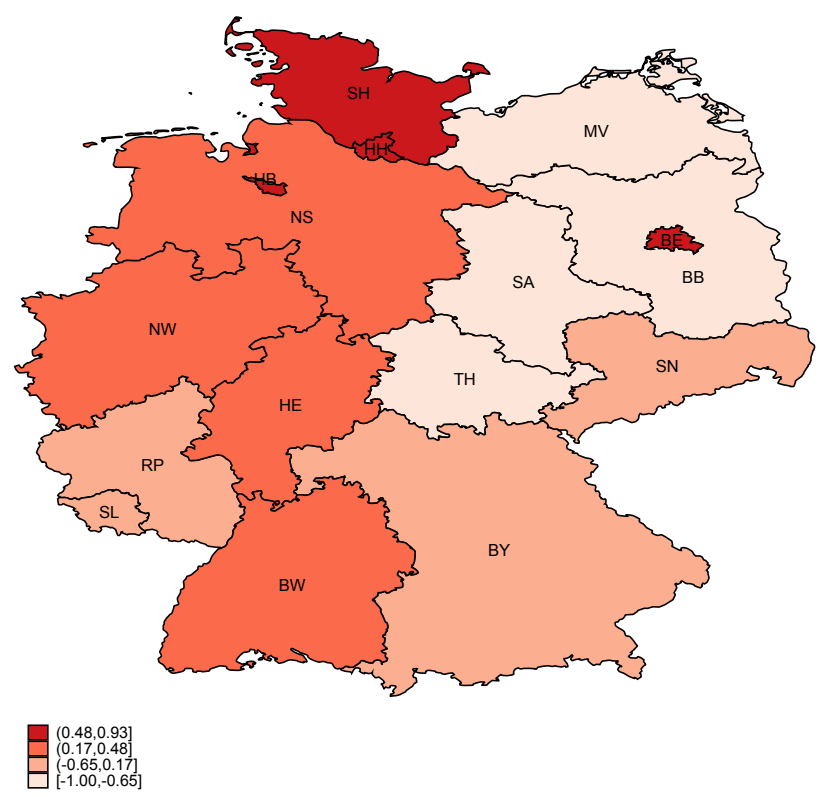

Note: Figure 1 plots the Migrant Acceptance Index at state level. Source: European Social Survey (2014). Abbreviations are as follows: SH - Schleswig Holstein; HH - Hamburg; NS - Lower Saxony; HB - Bremen; NW - North Rhine-Westphalia; HE - Hessen; RP - Rhineland Palatine ; BW - Baden Wurttemberg; BY - Bavaria; SL - Saarland; BE - Berlin; BB Brandenburg; MV - Mecklenburg-West Pomerania; SN - Saxony; SA - Saxony Anhalt; TH - Thuringia.

strongly associated with the MAI and with the expected pairwise comparisons. For example, we find that the correlation between our MAI and Gallup Diversity Index (some worries about immigration) is 0.79 (0.78). The raw correlation between MAI and AfD vote is 0.53. Overall, these patterns suggest that the Migrant Acceptance Index is strongly associated with other measures and the index is very likely to capture the meaningful differences in migrant attitudes.

\subsection{Diversity Index from Gallup World Polls}

We also use readily available "Diversity Index" from Gallup World Polls to check the robustness of our Migrant Acceptance Index. The Diversity Index measures a community's acceptance of people from different racial, ethnic, or cultural groups. We again use data from 2014 at the state level.

The index is constructed using the following questions: (i) is the city or area where you live a good place or not a good place to live for racial and ethnic minorities?; (ii) is the city or area where you live a good place or not a good place to live for gay or lesbian people?; (iii) is the city or area where you live a good place or not a good place to live for immigrants from other countries?; (iv) is the city or area where you live a good place or not a good place to live for people with intellectual disabilities?

Index scores are calculated at the individual record level. For each individual record the following procedure applies: The four items are recoded so that positive answers are scored as a "1" and all other answers 
(including don't know and refused) are assigned a score of "0". If a record has no answer for an item then that item is not eligible for inclusion in the calculations. An individual record has an index calculated if it has valid scores for at least three items. A record's final index score is the mean of valid items multiplied by 100. To ensure comparability, we again standardize the index (with mean zero and standard deviation one) and it ranges from -1 to 1 . Higher values indicate more positive attitudes. Similar to the Migrant Acceptance Index, Figure A6 indicates that the Diversity Index is more favorable in western Germany and Germany's city states.

\subsection{Descriptive Statistics}

Table 2 presents descriptive statistics for our working sample from the IAB-BAMF-SOEP Survey of Refugees. For the full sample, we find that a majority of survey respondents are male (about 60 percent). On average, they have been in Germany for about 2.7 years. In terms of human capital, nearly 12 (48) percent of refugees have tertiary (secondary) education as their highest level of education. When it comes to language skills, respondents are asked to assess their German proficiency (reading, writing, and speaking) on a 5-point likert scale from 1 "not at all" to 5 "very good". We find that refugees' average language skill score is about 3. As expected, Syrians (about 50 percent), Afghanis (about 13 percent), and Iraqis (about 14 percent) are the most common nationalities we have in our sample. This is also in line with a recent report from the Federal Office of Migration and Refugees (BAMF 2017), which reports these to be the main origin countries in 2016, and, hence, suggests good representativeness of our sample in terms of nationalities. ${ }^{18}$

Table A2 presents refugees' main activities separately for both genders, and for men and women separately by the number of years since arrival. Similar to Brücker et al. (2020) and Brell et al. (2020), we find that the percentage of refugees not being in employment or training decreases with years of residence in Germany and that after three years of residence in Germany roughly 30 percent of refugees are employed. ${ }^{19}$

There are also major gender differences: less than 7 percent of women are employed full- or part-time, while 28 percent of men are. While men and women are about equally likely to go to school or university, the share of women taking part in vocational training or apprenticeship is much lower than among men. Irrespective of the duration of stay in Germany, the share of women who are employed or in education or training is considerably lower than among men. While the share of those employed and the share of those studying or participating in vocational training increase over time, a majority of female refugees remains unemployed even after five years in Germany. Part of this gender gap is related to the presence of children:

\footnotetext{
${ }^{18}$ For 2016, the BAMF reports Syria, Afghanistan, and Iraq to be the main origin countries with 37 , 17 , and 13 percent respectively.

${ }^{19}$ These numbers further correspond to administrative records from August 2018, which show that three years after the refugee influx into Germany 28 percent of people from countries at war (including Afghanistan, Eritrea, Iraq, Iran, Nigeria, Pakistan, Somalia, and Syria) are employed.
} 
Table 2: Descriptive statistics from the IAB-BAMF-SOEP Survey of Refugees

\begin{tabular}{|c|c|c|c|}
\hline & $\begin{array}{c}(1) \\
\text { Full sample } \\
\text { mean/sd }\end{array}$ & $\begin{array}{c}(2) \\
\text { Males } \\
\text { mean/sd }\end{array}$ & $\begin{array}{c}(3) \\
\text { Females } \\
\text { mean } / \mathrm{sd}\end{array}$ \\
\hline Female gender & $\begin{array}{c}0.387 \\
(0.487)\end{array}$ & $\begin{array}{c}0.000 \\
(0.000)\end{array}$ & $\begin{array}{c}1.000 \\
(0.000)\end{array}$ \\
\hline Age in years & $\begin{array}{l}32.163 \\
(8.269)\end{array}$ & $\begin{array}{l}31.879 \\
(8.371)\end{array}$ & $\begin{array}{l}32.614 \\
(8.087)\end{array}$ \\
\hline Married & $\begin{array}{c}0.638 \\
(0.481)\end{array}$ & $\begin{array}{c}0.562 \\
(0.496)\end{array}$ & $\begin{array}{c}0.758 \\
(0.428)\end{array}$ \\
\hline Children in household & $\begin{array}{c}0.541 \\
(0.498)\end{array}$ & $\begin{array}{c}0.429 \\
(0.495)\end{array}$ & $\begin{array}{c}0.719 \\
(0.450)\end{array}$ \\
\hline Years of schooling & $\begin{array}{c}8.497 \\
(4.387)\end{array}$ & $\begin{array}{c}8.750 \\
(4.228)\end{array}$ & $\begin{array}{c}8.096 \\
(4.601)\end{array}$ \\
\hline Secondary education & $\begin{array}{c}0.477 \\
(0.500)\end{array}$ & $\begin{array}{c}0.494 \\
(0.500)\end{array}$ & $\begin{array}{c}0.450 \\
(0.498)\end{array}$ \\
\hline Tertiary education & $\begin{array}{c}0.121 \\
(0.326)\end{array}$ & $\begin{array}{c}0.120 \\
(0.325)\end{array}$ & $\begin{array}{c}0.122 \\
(0.328)\end{array}$ \\
\hline Worked in home country & $\begin{array}{c}0.656 \\
(0.475)\end{array}$ & $\begin{array}{c}0.838 \\
(0.369)\end{array}$ & $\begin{array}{c}0.368 \\
(0.483)\end{array}$ \\
\hline Average language skills & $\begin{array}{c}3.105 \\
(0.965)\end{array}$ & $\begin{array}{c}3.268 \\
(0.926)\end{array}$ & $\begin{array}{c}2.848 \\
(0.970)\end{array}$ \\
\hline Years since arrival & $\begin{array}{c}2.681 \\
(0.719)\end{array}$ & $\begin{array}{c}2.730 \\
(0.718)\end{array}$ & $\begin{array}{c}2.604 \\
(0.713)\end{array}$ \\
\hline In education or employment & $\begin{array}{c}0.277 \\
(0.448)\end{array}$ & $\begin{array}{c}0.380 \\
(0.485)\end{array}$ & $\begin{array}{c}0.114 \\
(0.318)\end{array}$ \\
\hline Syrian & $\begin{array}{c}0.525 \\
(0.499)\end{array}$ & $\begin{array}{c}0.519 \\
(0.500)\end{array}$ & $\begin{array}{c}0.535 \\
(0.499)\end{array}$ \\
\hline Afghan & $\begin{array}{c}0.130 \\
(0.336)\end{array}$ & $\begin{array}{c}0.128 \\
(0.334)\end{array}$ & $\begin{array}{c}0.133 \\
(0.339)\end{array}$ \\
\hline Iraqi & $\begin{array}{c}0.136 \\
(0.343)\end{array}$ & $\begin{array}{c}0.138 \\
(0.345)\end{array}$ & $\begin{array}{c}0.134 \\
(0.341)\end{array}$ \\
\hline$N$ & 3524 & 2159 & 1365 \\
\hline
\end{tabular}

Note: Means (standard deviations). Secondary education refers to 9 to 15 years of education and tertiary education refers to completed four years of education beyond "secondary education". Average German language proficiency levels (speaking, writing, reading) are measured on a scale from 1 "not at all" to 5 "very good". Years since arrival is defined as the difference between year of the interview and year of arrival. Being in employment or education is equal to one for IAB-BAMF-SOEP survey respondents in employment or education. Source: IAB-BAMF-SOEP Survey of Refugees, v35 (2016-2018).

72 of female refugees report to have a minor child in the household, in contrast to 43 percent of male refugees.

However, Table A3 shows that major gender differences remain even if attention is restricted to singles without children.

Analyzing the main activities for different age groups demonstrates that a considerable number of respondents in their early adulthood are studying (about 13 percent attend school, university or vocational training-see Appendix Table A4). For refugees younger than 50, the probability of not being in employment or education decreases with residence duration in Germany. Refugees aged 25-49 are most likely to be employed full- or part-time. Older refugees struggle to participate in local labor markets: 73 percent of refugees aged $50+$ are not in employment or education and even after 4 years of residence in Germany their labor market participation remains low. Only about 20 percent are employed full- or part-time. 


\section{Empirical Strategy}

We estimate linear probability models for the dichotomous outcomes for ease of interpretation, though logistic regression models returned similar patterns. For continuous outcomes, we rely on ordinary least squared estimations (OLS). Our models take the form:

$$
Y_{i c t}=\beta_{1} U E_{c, t-2}+\beta_{2} M A I_{s_{0}, 2014}+\gamma X_{i t}+\delta X_{c t}+\eta_{t}+\zeta_{\text {nuts } 2}+\epsilon_{i c t},
$$

where $Y_{i c t}$ is the integration outcome of refugee $i$ in county $c$ and interview year $t$. We use several measures for refugees' social and economic integration in Germany: (i) being in employment or education; (ii) being in full- or part-time employment; (iii) the net monthly wages; and (iv) the Multi-dimensional Integration Index. Since the wage variable has a few outliers and substantial number of zeros, the natural logarithm is an unsuitable transformation. We, therefore, follow common practice and apply the inverse hyperbolic sine transformation (see, Bellemare and Wichman (2020) and Aksoy et al. (2020)).

Following Aslund and Rooth (2007), the variable $U E_{c, t-2}$ measures the county-level unemployment rate in year t-2 ( $\mathrm{t}$ being the year of the interview) in the initial county of residence to address endogeneity of unemployment in response to mass migration. $M A I_{s_{0}, 2014}$ is the Migrant Acceptance Index in the refugee's initial state of residence, measured in $2014 .{ }^{20}$ To be able to compare the point estimates, we report the standardized coefficients throughout the paper. Importantly, raw correlation between initial unemployment rate and the Migrant Acceptance Index is very low (-0.19), suggesting that attitudes do not co-move with unemployment. This enables us to estimate the impact of local unemployment on refugee integration, holding attitudes constant and vice versa.

In all models, we include year of interview dummies (to capture the impact of county-level shocks that affect all counties simultaneously) and NUTS-2 sub-region dummies (to control for time-invariant variation in the outcome variables caused by factors that vary across sub-regions). ${ }^{21}$ In the robustness section, we also show that our results do not change qualitatively when we include NUTS-2*year fixed effects, which control for all potentially omitted variables that can vary across NUTS-2 regions and years.

$X_{i t}$ is a vector of demographic variables that includes: a dummy variable for female gender; a dummy variable for the presence of children in the household (any child aged 15 or below); a dummy for the German

\footnotetext{
${ }^{20}$ Due to data limitations we can only construct the Migrant Acceptance Index at the state level instead of county-level. While there may be some within-state variation in attitudes towards migrants, it is worth noting that cross-state differences in attitudes are much larger in the context of Germany. In robustness section, we also use alternative measures (that is, the AfD vote share in 2013 and the share of respondents who reported some or big worries about immigration in 2014) to capture attitudes towards migrants at the county level and find qualitatively similar results.

${ }^{21}$ We cannot include county-fixed effects since county-level unemployment rates are strongly correlated over time and migration across counties is restricted. Regressions with county-level unemployment rates thereby underestimate the effect of initial unemployment. Instead, we include NUTS-2 sub-region fixed effects throughout.
} 
language skills before migration; ${ }^{22}$ a dummy variable for having received help in finding employment; a dummy variable for having received support from family or friends before migration; age group dummies (25-29, 30-34, 35-39, 40-44, 45-49); education dummies (secondary education, tertiary education); country of origin dummies (Afghan origin, Iraqi origin, other origin); dummy variables for years of residence in Germany (three years of residence, four years of residence); a dummy variable indicating residence in western Germany. $X_{c t}$ is a vector of county-level control variables that includes: the share of Syrians, Afghans, and Iraqis in the county of residence in 2014-these covariates control for the existing migrant networks.

We cluster robust standard errors, $\epsilon_{i c t}$, at the level of county to account for the potential correlation existing in the errors within the same county. Our results remain virtually the same, when standard errors are calculated using corrections for spatial correlation (Conley 1999) ${ }^{23}$ and clustered at the state level. ${ }^{24}$

\section{Identification assumption}

Our identification strategy exploits the German refugee settlement policy as a quasi-natural experiment to identify the causal effect of local conditions (in terms of economic conditions and attitudes towards immigrants) on refugees' socio-economic integration. As discussed in Section 2.1, the exogenous allocation of refugees across counties addresses the bias from endogenous sorting due to growing demand for labor (Card 1990) or pre-existing ethnic enclaves (Edin et al. 2003). Our key identifying assumption is that the allocation of refugees is independent of county-level unemployment rates and state-level migrant attitudes in Germany in the year of arrival.

To further validate this argument, we provide an indirect test following Barsbai et al. (2019). If the distribution of refugees is indeed exogenous to local conditions, unemployment rates and state-level attitudes towards migrants should be uncorrelated with refugees' individual-level characteristics. Table 3 shows the results, whereby column (1) and (2) restrict the sample to refugees who were interviewed in the first two years after arrival and column (3) and (4) use the full sample. In line with our identification assumption, for the sample of recent arrivals, none of the estimates is statistically significant. For the full sample, we find a small positive correlation of female gender with the Migrant Acceptance Index, but the effect is far from being economically significant. Overall, the results presented in Table 3 support our argument that the allocation of refugees is an exogenous process.

\footnotetext{
${ }^{22}$ The respective survey question asks: How well could you speak German before you moved to Germany? [Not at all; Poorly; Fairly; Good; Very good]. The dummy variable takes a value of one for refugees with at least "good" German skills and zero otherwise.

${ }^{23}$ In particular, we use statistical package, acreg, provided by Colella et al. (2019). The cut-off window we use is $100 \mathrm{~km}$, but the results are virtually unchanged for $75 \mathrm{~km}, 125 \mathrm{~km}$, and $150 \mathrm{~km}$-the results with alternative distance cut-offs are not reported here but available upon request.

${ }^{24}$ These results are reported in Appendix.
} 
Table 3: Evidence on the validity of identification assumption

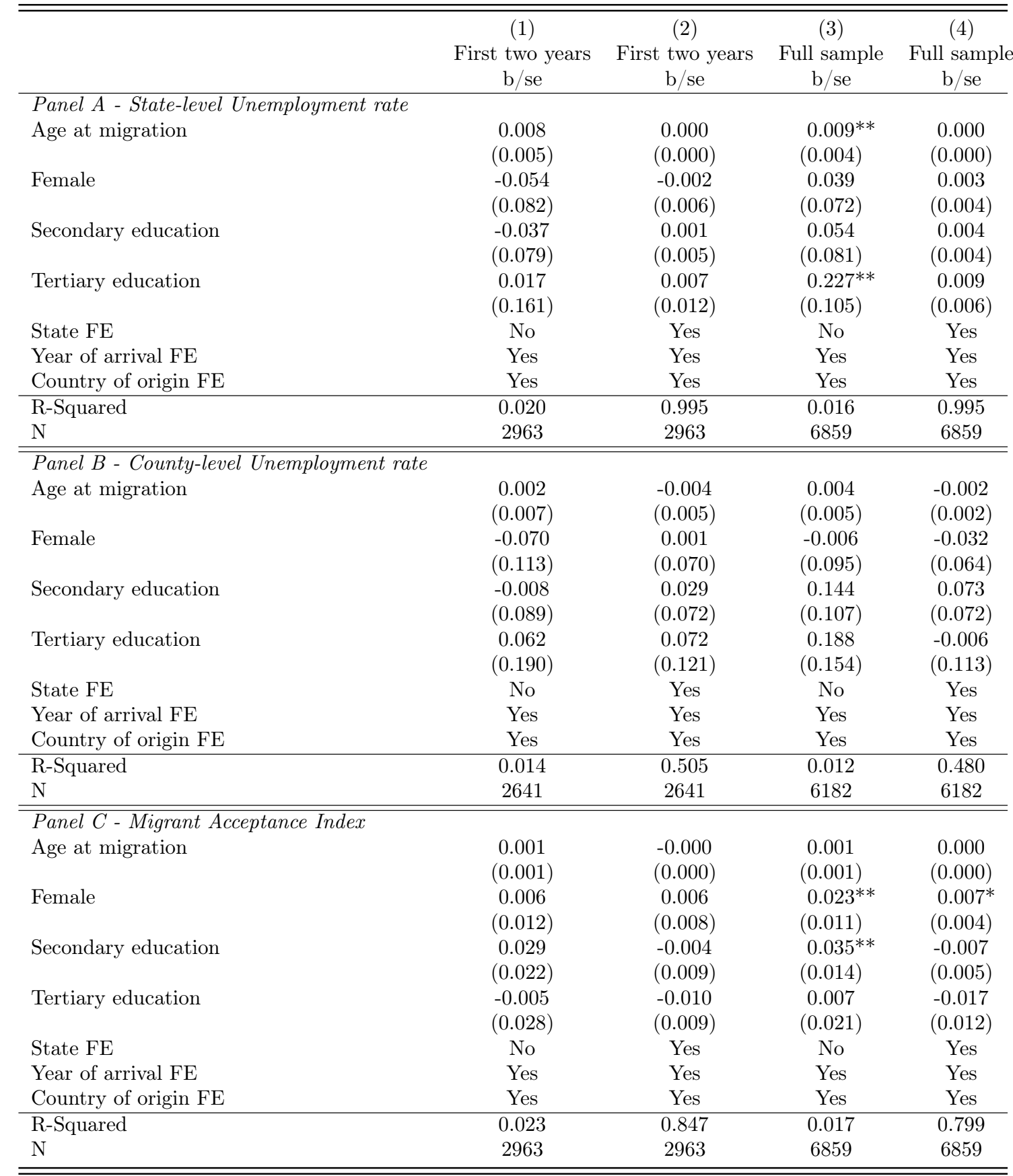

Note: ${ }^{*}$ significant at $10 \% ;{ }^{* *}$ significant at $5 \% ; * * *$ significant at $1 \%$. The standard errors are clustered on the state and year of arrival level and are displayed in parentheses. We pool observations from survey years 2016 to 2018 keeping only the most recent survey information. Reference category is primary education. Source: IAB-BAMF-SOEP Survey of Refugees, v35 (2016-2018) and European Social Survey (2014). 


\section{$5 \quad$ Results}

In this section, we start by analyzing how local labor market conditions and attitudes towards immigrants at the time of arrival affect refugees' multi-dimensional integration outcomes. We then investigate the heterogeneity using causal forest methodology and present robustness checks.

\subsection{Multi-dimensional Integration Outcomes}

We first examine the effects of local conditions at the time of arrival (that is, unemployment rate and attitudes towards immigrants) on the probability of being in employment or education (Column 1 of Table 4); being in full- or part-time employment (Column 2 of Table 4); net monthly wages (Column 3 of Table 4); and Multi-dimensional Integration Index (Column 4 of Table 4). We present results for refugees aged 18 to 49 in the year of the interview and, as noted above, the sample is restricted to those with a minimum of two years of residence in Germany.

Table 4 shows that both the county-level unemployment rate in year t-2 ( $\mathrm{t}$ being the year of the interview) and MAI play a major role: one standard deviation (0.98) increase in county-level unemployment rate leads to a -4.3 (-4.2) percentage points change in the likelihood of being in employment or education (full- or parttime employment). The point estimates on MAI (that is, more favorable attitudes towards migrants) suggest that a one standard deviation increase in the Migrant Acceptance Index leads to a 5.0 (4.7) percentage points increase in the likelihood of being in employment or education (full- or part-time employment).

We also find that both unemployment rate and MAI have statistically significant effects on net monthly wages-with effects going in opposite directions (as expected) and the effect of unemployment being about twice as large as the effect of the MAI. In Column 4, we find that more favorable attitudes towards migrants positively affect their multi-dimensional integration, while unemployment has the opposite effect. The magnitude of the standardized coefficients suggests that attitudes towards migrants are as important as the local unemployment rate when it comes to multi-dimensional integration of refugees. ${ }^{25}$

Looking at other covariates, we find that those who received help to find a job, those with tertiary education and those with satisfactory health status consistently exhibit better integration outcomes.

\footnotetext{
${ }^{25}$ Since help finding a job is part of the navigational index, hence, part of the multi-dimensional integration index, we don't control for it in Column 4.
} 
Table 4: Determinants of refugees' labor market and social outcomes

\begin{tabular}{|c|c|c|c|c|}
\hline & $\begin{array}{c}(1) \\
\text { In employment } \\
\text { or education } \\
\text { b/se }\end{array}$ & $\begin{array}{c}(2) \\
\text { Full or } \\
\text { part-time } \\
\text { b/se }\end{array}$ & $\begin{array}{c}(3) \\
\text { Net monthly wages } \\
\mathrm{b} / \mathrm{se}\end{array}$ & $\begin{array}{c}(4) \\
\text { Multi-dimensional } \\
\text { Integration Index } \\
\mathrm{b} / \mathrm{se}\end{array}$ \\
\hline Unemployment rate t-2 std. & $\begin{array}{l}-0.043^{* * *} \\
(0.013)\end{array}$ & $\begin{array}{l}-0.042^{* * *} \\
(0.012)\end{array}$ & $\begin{array}{l}-0.341^{* * *} \\
(0.084)\end{array}$ & $\begin{array}{l}-0.014^{* *} \\
(0.007)\end{array}$ \\
\hline Migrant Acceptance Index std. & $\begin{array}{l}0.050^{* * *} \\
(0.016)\end{array}$ & $\begin{array}{l}0.047^{* * *} \\
(0.013)\end{array}$ & $\begin{array}{c}0.178^{*} \\
(0.092)\end{array}$ & $\begin{array}{c}0.011^{*} \\
(0.006)\end{array}$ \\
\hline Female & $\begin{array}{l}-0.196^{* * *} \\
(0.014)\end{array}$ & $\begin{array}{l}-0.174^{* * *} \\
(0.013)\end{array}$ & $\begin{array}{l}-1.286^{* * *} \\
(0.093)\end{array}$ & $\begin{array}{l}-0.081^{* * *} \\
(0.005)\end{array}$ \\
\hline Secondary education & $\begin{array}{l}0.039^{* *} \\
(0.015)\end{array}$ & $\begin{array}{c}0.021 \\
(0.015)\end{array}$ & $\begin{array}{c}0.114 \\
(0.107)\end{array}$ & $\begin{array}{l}0.040^{* * *} \\
(0.007)\end{array}$ \\
\hline Tertiary education & $\begin{array}{l}0.061^{* * *} \\
(0.021)\end{array}$ & $\begin{array}{l}0.049^{* *} \\
(0.021)\end{array}$ & $\begin{array}{l}0.391^{* *} \\
(0.152)\end{array}$ & $\begin{array}{l}0.065^{* * *} \\
(0.010)\end{array}$ \\
\hline Participated in integration course & $\begin{array}{c}0.002 \\
(0.018)\end{array}$ & $\begin{array}{l}-0.007 \\
(0.016)\end{array}$ & $\begin{array}{l}-0.004 \\
(0.112)\end{array}$ & $\begin{array}{l}0.041^{* * *} \\
(0.006)\end{array}$ \\
\hline German skills before emigration & $\begin{array}{c}0.051 \\
(0.048)\end{array}$ & $\begin{array}{l}-0.009 \\
(0.041)\end{array}$ & $\begin{array}{c}0.200 \\
(0.370)\end{array}$ & $\begin{array}{l}0.072^{* * *} \\
(0.017)\end{array}$ \\
\hline Help finding a job & $\begin{array}{l}0.179^{* * *} \\
(0.023)\end{array}$ & $\begin{array}{l}0.133^{* * *} \\
(0.022)\end{array}$ & $\begin{array}{l}1.357^{* * *} \\
(0.180)\end{array}$ & \\
\hline $\begin{array}{c}\text { Support from family \& friends } \\
\text { before emigration }\end{array}$ & -0.028 & -0.018 & $-0.271^{* *}$ & 0.002 \\
\hline & $(0.018)$ & $(0.018)$ & $(0.127)$ & $(0.007)$ \\
\hline Children in household & $\begin{array}{l}-0.074^{* * *} \\
(0.019)\end{array}$ & $\begin{array}{l}-0.075^{* * *} \\
(0.019)\end{array}$ & $\begin{array}{l}-0.604^{* * *} \\
(0.138)\end{array}$ & $\begin{array}{c}0.003 \\
(0.009)\end{array}$ \\
\hline Married/ In partnership & $\begin{array}{l}-0.044^{* *} \\
(0.021)\end{array}$ & $\begin{array}{c}0.017 \\
(0.023)\end{array}$ & $\begin{array}{c}0.051 \\
(0.151)\end{array}$ & $\begin{array}{l}-0.024^{* * *} \\
(0.008)\end{array}$ \\
\hline Satisfactory health status & $\begin{array}{l}0.061^{* * *} \\
(0.021)\end{array}$ & $\begin{array}{l}0.053^{* * *} \\
(0.017)\end{array}$ & $\begin{array}{l}0.277^{* *} \\
(0.129)\end{array}$ & $\begin{array}{l}0.044^{* * *} \\
(0.010)\end{array}$ \\
\hline Interview year $\mathrm{FE}$ & Yes & Yes & Yes & Yes \\
\hline Nuts-2 FE & Yes & Yes & Yes & Yes \\
\hline R-Squared & 0.229 & 0.205 & 0.228 & 0.253 \\
\hline $\mathrm{N}$ & 3170 & 2434 & 3013 & 2477 \\
\hline
\end{tabular}

Note: ${ }^{*}$ significant at 10\%; ${ }^{* *}$ significant at $5 \% ;{ }^{* *}$ significant at $1 \%$. The standard errors are clustered on the county level and are displayed in parentheses. We pool observations from survey years 2016 to 2018 keeping only the most recent survey information. The sample is restricted to individuals with a minimum of two years of residence in Germany. Outcome variable "In employment or education" takes a value of one for refugees who report being in employment or education. Outcome variable "Full- or part-time employed" is one for refugees who report being in full- or part-time employment. Outcome "Net monthly wages" are net monthly wages, in inverse hyperbolic sine transformation. Table 4 includes the full set of covariates, as described in Section 4. For illustrative purposes, some control variables are not shown. For the full set of variables, please check Table A5. Reference categories are as follows: primary education, aged 18-24 (aged 25-29 for full- or part-time employment), two years of residence in Germany, and Syrian origin. Information on attitudes stems from the European Social Survey. We merge natives' mean values on attitudes towards immigrants based on refugees' year of arrival and first state of residence in Germany. Source: IAB-BAMF-SOEP Survey of Refugees, v35 (2016-2018) and European Social Survey (2014). 


\subsection{Fiscal Implications of our Results}

Refugees with a valid residence status who are not in employment or education are entitled to the same social benefits as natives in Germany. ${ }^{26}$ Since few refugees have been employed for a period of 12 months, this means that refugees who are unemployed receive on average $€ 400$ of monthly unemployment benefits II ("Hartz IV"), corresponding to $€ 4800$ per year. This is an underestimate of the actual cost to the state of refugees' unemployment, as it excludes government spending on housing and health care, social benefits, as well as lost tax revenues.

Our estimations suggest that placing a working-age refugee aged 25 to 49 in a county with a one standard deviation lower county-level unemployment rate increases the probability of them being in full- or part-time employment after two years by 4.2 percentage points. Clearly, it would not be possible to place all refugees in more desirable locations without general equilibrium effects through higher labor supply which would negate part of the gains. Still, already a smaller-scale relocation of, say, 10,000 randomly selected working-age refugees to a county with a one standard deviation lower unemployment rate would generate an annual saving of more than $€ 2$ million $\left(0.042^{*} 10,000^{*} 4800=2,016,000\right)$. Increasing the scope of reallocation would mean that part of the savings would be lost due to general equilibrium effects, but as we also exclude public finance benefits from taxes and social insurance contributions that employed refugees pay, overall public finance benefits could be higher even once general equilibrium effects were accounted for. Furthermore, it is important to note that this calculation takes into account the effect after only two to four years in Germany. To the extent that earlier integration into the labor market would also boost subsequent employment outcomes, dynamic gains over refugees' remaining working life in Germany could be substantial. Reallocation to states with one standard deviation higher Migrant Acceptance Index would generate public finance benefits of the same order of magnitude.

\subsection{Unbundling the Multi-dimensional Integration Index}

This section explores how unemployment rate and the MAI affect the components of Multi-dimensional Integration Index.

In Table 5, we consider six sub-indices of the Multi-dimensional Integration Index. The outcomes across the columns are as follows: Psychological Integration in Column 1; Linguistic Integration in Column 2; Economic Integration in Column 3; Political Integration in Column 4; Social Integration in Column 5; and Navigational Integration in Column 6.

The results suggest that both the unemployment rate and the MAI are relevant in explaining social and

\footnotetext{
${ }^{26} \mathrm{See}$ https://www.asylumineurope.org/reports/country/germany/content-international-protection/social-welfare (last downloaded 02.11.2020).
} 
economic components of the index with similar point estimates. Yet we find no evidence that the unemployment rate or the MAI affects psychological, linguistic, political, or navigational integration outcomes.

Although we view this as an exploratory exercise rather than a testing of a specific hypothesis, our results suggest that attitudes towards migrants not only matter for refugees' economic integration but also affect their social integration into the host country. This finding is important as previous literature has not paid much attention to the role of attitudes towards immigrants in refugees' integration.

\subsection{Gender Differences}

As shown already in Table 2, there is a major gender difference in refugees' integration outcomes, with 38 percent of men, but only 11 percent of women, being in education or employment. Therefore, we next analyze the effects of initial conditions on refugees' labor market and social outcomes separately by gender.

Table 6 shows the effects of initial unemployment and the Migrant Acceptance Index in Panel A for males and in Panel B for females. The effects are considerably stronger for males. Higher initial local unemployment reduces males' chances of being in employment or education, the effect being almost identical when analyzing full- or part-time employment, and also depresses net monthly wages and values of the Multi-dimensional Integration Index. For females, only the effect on net monthly wages is statistically significant. The Migrant Acceptance Index, in turn, predicts a higher probability of males being in employment or education and being in full or part-time employment. For females, the Migrant Acceptance Index has a somewhat smaller effect than on males on the probability of being in employment or education, but no effect on full- or part-time employment.

Higher education is associated with better multi-dimensional integration outcomes for both males and females, and those with secondary education are more likely to be in employment or education. Tertiary education increases the likelihood of being in employment or education, as well as likelihood of being employed and net monthly wages for males, but has no statistically significant effect on employment outcomes for females. Both males and females with children in household are less likely to be in employment or education, and earn less.

In Table A6, we analyze the effects of initial unemployment and the Migrant Acceptance Index on different dimensions of the Multi-dimensional Integration Index. Initial unemployment strongly reduces males' economic integration, and is also associated with worse navigational outcomes, although the effect is weaker. For females, the only effect is a counter-intuitive marginally statistically significant positive effect on navigational outcomes. The Migrant Acceptance Index is related to better economic integration for both genders, but the effect is statistically significant only for females. Its other effects are statistically insignificant. 
Table 5: Effect of unemployment and attitudes towards immigrants on the dimensions of the Multidimensional Integration Index

\begin{tabular}{|c|c|c|c|c|c|c|}
\hline & $\begin{array}{c}(1) \\
\text { Psychological } \\
\text { b/se }\end{array}$ & $\begin{array}{c}(2) \\
\text { Linguistic } \\
\text { b/se }\end{array}$ & $\begin{array}{c}(3) \\
\text { Economic } \\
\text { b/se }\end{array}$ & $\begin{array}{c}(4) \\
\text { Political } \\
\text { b/se }\end{array}$ & $\begin{array}{c}(5) \\
\text { Social } \\
\text { b/se }\end{array}$ & $\begin{array}{c}(6) \\
\text { Navigational } \\
\mathrm{b} / \mathrm{se}\end{array}$ \\
\hline Unemployment rate t-2 std. & $\begin{array}{l}-0.001 \\
(0.012)\end{array}$ & $\begin{array}{l}-0.002 \\
(0.009)\end{array}$ & $\begin{array}{l}-0.036^{* * *} \\
(0.012)\end{array}$ & $\begin{array}{c}0.001 \\
(0.006)\end{array}$ & $\begin{array}{l}-0.025^{*} \\
(0.015)\end{array}$ & $\begin{array}{l}-0.010 \\
(0.012)\end{array}$ \\
\hline Migrant Acceptance Index std. & $\begin{array}{c}0.016 \\
(0.012)\end{array}$ & $\begin{array}{l}-0.005 \\
(0.008)\end{array}$ & $\begin{array}{l}0.033^{* *} \\
(0.013)\end{array}$ & $\begin{array}{l}-0.013 \\
(0.008)\end{array}$ & $\begin{array}{l}0.027^{* *} \\
(0.014)\end{array}$ & $\begin{array}{l}-0.003 \\
(0.012)\end{array}$ \\
\hline Female & $\begin{array}{c}0.006 \\
(0.008)\end{array}$ & $\begin{array}{l}-0.071^{* * *} \\
(0.010)\end{array}$ & $\begin{array}{l}-0.213^{* * *} \\
(0.012)\end{array}$ & $\begin{array}{l}-0.007 \\
(0.006)\end{array}$ & $\begin{array}{l}-0.093^{* * *} \\
(0.012)\end{array}$ & $\begin{array}{l}-0.045^{* * *} \\
(0.011)\end{array}$ \\
\hline Secondary education & $\begin{array}{l}-0.010 \\
(0.010)\end{array}$ & $\begin{array}{l}0.122^{* * *} \\
(0.009)\end{array}$ & $\begin{array}{c}0.024^{*} \\
(0.014)\end{array}$ & $\begin{array}{c}0.006 \\
(0.006)\end{array}$ & $\begin{array}{l}0.059^{* * *} \\
(0.012)\end{array}$ & $\begin{array}{c}0.004 \\
(0.013)\end{array}$ \\
\hline Tertiary education & $\begin{array}{l}-0.032^{* *} \\
(0.016)\end{array}$ & $\begin{array}{l}0.240^{* * *} \\
(0.013)\end{array}$ & $\begin{array}{l}0.061^{* * *} \\
(0.019)\end{array}$ & $\begin{array}{c}0.011 \\
(0.008)\end{array}$ & $\begin{array}{l}0.042^{* *} \\
(0.018)\end{array}$ & $\begin{array}{c}0.026 \\
(0.023)\end{array}$ \\
\hline Participated in integration course & $\begin{array}{l}0.038^{* * *} \\
(0.009)\end{array}$ & $\begin{array}{l}0.072^{\text {*** }} \\
(0.009)\end{array}$ & $\begin{array}{l}0.121^{* * *} \\
(0.015)\end{array}$ & $\begin{array}{l}-0.001 \\
(0.006)\end{array}$ & $\begin{array}{c}0.013 \\
(0.013)\end{array}$ & $\begin{array}{l}-0.018 \\
(0.012)\end{array}$ \\
\hline German skills before emigration & $\begin{array}{l}-0.007 \\
(0.024)\end{array}$ & $\begin{array}{l}0.109^{* * *} \\
(0.025)\end{array}$ & $\begin{array}{c}0.077^{*} \\
(0.042)\end{array}$ & $\begin{array}{c}0.016 \\
(0.010)\end{array}$ & $\begin{array}{l}0.111^{* * *} \\
(0.030)\end{array}$ & $\begin{array}{c}0.062 \\
(0.042)\end{array}$ \\
\hline $\begin{array}{l}\text { Support from family \& friends } \\
\text { before emigration }\end{array}$ & $0.024^{* *}$ & -0.012 & -0.011 & 0.004 & -0.011 & 0.020 \\
\hline & $(0.011)$ & $(0.010)$ & $(0.016)$ & $(0.005)$ & $(0.016)$ & $(0.014)$ \\
\hline Children in household & $\begin{array}{l}0.053^{* * *} \\
(0.013)\end{array}$ & $\begin{array}{c}0.007 \\
(0.011)\end{array}$ & $\begin{array}{l}-0.071^{* * *} \\
(0.018)\end{array}$ & $\begin{array}{c}0.001 \\
(0.008)\end{array}$ & $\begin{array}{c}0.001 \\
(0.018)\end{array}$ & $\begin{array}{c}0.023 \\
(0.017)\end{array}$ \\
\hline Married/ In partnership & $\begin{array}{l}-0.003 \\
(0.013)\end{array}$ & $\begin{array}{l}-0.045^{* * *} \\
(0.012)\end{array}$ & $\begin{array}{l}-0.012 \\
(0.019)\end{array}$ & $\begin{array}{c}0.005 \\
(0.008)\end{array}$ & $\begin{array}{l}-0.046^{* *} \\
(0.018)\end{array}$ & $\begin{array}{l}-0.020 \\
(0.016)\end{array}$ \\
\hline Satisfactory health status & $\begin{array}{l}0.059^{* * *} \\
(0.015)\end{array}$ & $\begin{array}{l}0.052^{* * *} \\
(0.013)\end{array}$ & $\begin{array}{l}0.051^{* * *} \\
(0.019)\end{array}$ & $\begin{array}{c}0.020 \\
(0.012)\end{array}$ & $\begin{array}{l}0.062^{* * *} \\
(0.020)\end{array}$ & $\begin{array}{l}-0.017 \\
(0.018)\end{array}$ \\
\hline Interview year FE & Yes & Yes & Yes & Yes & Yes & Yes \\
\hline Nuts-2 FE & Yes & Yes & Yes & Yes & Yes & Yes \\
\hline R-Squared & 0.078 & 0.356 & 0.266 & 0.056 & 0.157 & 0.065 \\
\hline $\mathrm{N}$ & 2477 & 2477 & 2477 & 2477 & 2477 & 2477 \\
\hline
\end{tabular}

Note: ${ }^{*}$ significant at 10\%; ${ }^{* *}$ significant at $5 \%$; *** significant at $1 \%$. The standard errors are clustered on the county level and are displayed in parentheses. We pool observations from survey years 2016 to 2018 keeping only the most recent survey information. The sample is restricted to individuals with a minimum of two years of residence in Germany. Dimensions are set similar to Harder et al. (2018). Table 5 includes the full set of covariates, as described in Section 4 . For illustrative purposes, some control variables are not shown. Reference categories are as follows: primary education, aged 18-24, two years of residence in Germany, and Syrian origin. Information on attitudes stems from the European Social Survey. We merge natives' mean values on attitudes towards immigrants based on refugees' year of arrival and first state of residence in Germany. Source: IAB-BAMF-SOEP Survey of Refugees, v35 (2016-2018) and European Social Survey (2014). 
Table 6: Determinants of refugees' labor market and social outcomes, by gender

\begin{tabular}{|c|c|c|c|c|}
\hline & $\begin{array}{c}(1) \\
\text { In employment } \\
\text { or education }\end{array}$ & $\begin{array}{c}\text { (2) } \\
\text { Full or } \\
\text { part-time }\end{array}$ & $\begin{array}{c}(3) \\
\text { Net monthly wages }\end{array}$ & $\begin{array}{l}\text { (4) } \\
\text { Multi-dimensional } \\
\text { Integration Index }\end{array}$ \\
\hline \multicolumn{5}{|l|}{ Panel A - Males } \\
\hline Unemployment rate t- 2 std. & $\begin{array}{l}-0.057^{* * *} \\
(0.016)\end{array}$ & $\begin{array}{l}-0.056^{* * *} \\
(0.017)\end{array}$ & $\begin{array}{l}-0.401^{* * *} \\
(0.121)\end{array}$ & $\begin{array}{l}-0.022^{* * *} \\
(0.008)\end{array}$ \\
\hline Migrant Acceptance Index std. & $\begin{array}{l}0.051^{* *} \\
(0.022)\end{array}$ & $\begin{array}{l}0.065^{* * *} \\
(0.020)\end{array}$ & $\begin{array}{c}0.176 \\
(0.130)\end{array}$ & $\begin{array}{c}0.009 \\
(0.007)\end{array}$ \\
\hline Secondary education & $\begin{array}{c}0.043^{*} \\
(0.023)\end{array}$ & $\begin{array}{c}0.027 \\
(0.024)\end{array}$ & $\begin{array}{c}0.150 \\
(0.172)\end{array}$ & $\begin{array}{l}0.040^{* * *} \\
(0.009)\end{array}$ \\
\hline Tertiary education & $\begin{array}{l}0.068^{* *} \\
(0.033)\end{array}$ & $\begin{array}{l}0.070^{* *} \\
(0.034)\end{array}$ & $\begin{array}{l}0.619^{* *} \\
(0.253)\end{array}$ & $\begin{array}{l}0.065^{* * *} \\
(0.013)\end{array}$ \\
\hline Participated in integration course & $\begin{array}{c}0.005 \\
(0.025)\end{array}$ & $\begin{array}{c}0.001 \\
(0.025)\end{array}$ & $\begin{array}{l}-0.077 \\
(0.167)\end{array}$ & $\begin{array}{l}0.022^{* * *} \\
(0.008)\end{array}$ \\
\hline German skills before emigration & $\begin{array}{c}0.074 \\
(0.062)\end{array}$ & $\begin{array}{l}-0.005 \\
(0.056)\end{array}$ & $\begin{array}{c}0.334 \\
(0.514)\end{array}$ & $\begin{array}{l}0.074^{* * *} \\
(0.023)\end{array}$ \\
\hline Help finding a job & $\begin{array}{l}0.186^{* * *} \\
(0.027)\end{array}$ & $\begin{array}{l}0.142^{* * *} \\
(0.028)\end{array}$ & $\begin{array}{l}1.402^{* * *} \\
(0.217)\end{array}$ & \\
\hline \multirow{2}{*}{$\begin{array}{l}\text { Support from family \& friends } \\
\text { before emigration }\end{array}$} & -0.042 & -0.026 & $-0.459^{* *}$ & 0.005 \\
\hline & $(0.028)$ & $(0.032)$ & $(0.213)$ & $(0.010)$ \\
\hline Children in household & $\begin{array}{l}-0.064^{* *} \\
(0.031)\end{array}$ & $\begin{array}{l}-0.093^{* * *} \\
(0.031)\end{array}$ & $\begin{array}{l}-0.646^{\text {*** }} \\
(0.235)\end{array}$ & $\begin{array}{c}0.012 \\
(0.013)\end{array}$ \\
\hline Interview year FE & Yes & Yes & Yes & Yes \\
\hline Nuts-2 FE & Yes & Yes & Yes & Yes \\
\hline R-Squared & 0.199 & 0.183 & 0.214 & 0.193 \\
\hline $\mathrm{N}$ & 1947 & 1454 & 1808 & 1527 \\
\hline \multicolumn{5}{|l|}{ Panel B - Females } \\
\hline Unemployment rate t- 2 std. & $\begin{array}{l}-0.012 \\
(0.014)\end{array}$ & $\begin{array}{c}-0.015 \\
(0.012)\end{array}$ & $\begin{array}{l}-0.200^{* * *} \\
(0.076)\end{array}$ & $\begin{array}{l}-0.006 \\
(0.009)\end{array}$ \\
\hline Migrant Acceptance Index std. & $\begin{array}{l}0.034^{* *} \\
(0.014)\end{array}$ & $\begin{array}{c}0.008 \\
(0.010)\end{array}$ & $\begin{array}{c}0.119 \\
(0.077)\end{array}$ & $\begin{array}{c}0.010 \\
(0.010)\end{array}$ \\
\hline Secondary education & $\begin{array}{c}0.035^{*} \\
(0.019)\end{array}$ & $\begin{array}{c}0.007 \\
(0.015)\end{array}$ & $\begin{array}{c}0.091 \\
(0.107)\end{array}$ & $\begin{array}{l}0.034^{* * *} \\
(0.009)\end{array}$ \\
\hline Tertiary education & $\begin{array}{c}0.045 \\
(0.028)\end{array}$ & $\begin{array}{c}0.005 \\
(0.018)\end{array}$ & $\begin{array}{c}0.099 \\
(0.157)\end{array}$ & $\begin{array}{l}0.061^{* * *} \\
(0.015)\end{array}$ \\
\hline Participated in integration course & $\begin{array}{l}-0.003 \\
(0.024)\end{array}$ & $\begin{array}{c}0.014 \\
(0.018)\end{array}$ & $\begin{array}{c}0.175 \\
(0.130)\end{array}$ & $\begin{array}{l}0.078^{* * *} \\
(0.010)\end{array}$ \\
\hline German skills before emigration & $\begin{array}{l}-0.012 \\
(0.070)\end{array}$ & $\begin{array}{l}-0.058^{* *} \\
(0.022)\end{array}$ & $\begin{array}{l}-0.246 \\
(0.408)\end{array}$ & $\begin{array}{c}0.049^{*} \\
(0.029)\end{array}$ \\
\hline Help finding a job & $\begin{array}{l}0.119^{* * *} \\
(0.043)\end{array}$ & $\begin{array}{l}0.070^{* *} \\
(0.030)\end{array}$ & $\begin{array}{l}0.980^{* * *} \\
(0.279)\end{array}$ & \\
\hline \multirow[t]{2}{*}{$\begin{array}{l}\text { Support from family \& friends } \\
\text { before emigration }\end{array}$} & -0.003 & 0.009 & 0.027 & -0.002 \\
\hline & $(0.020)$ & $(0.016)$ & $(0.119)$ & $(0.010)$ \\
\hline Children in household & $\begin{array}{l}-0.080^{* * *} \\
(0.025)\end{array}$ & $\begin{array}{l}-0.039^{* *} \\
(0.020)\end{array}$ & $\begin{array}{l}-0.440^{* * *} \\
(0.149)\end{array}$ & $\begin{array}{c}-0.001 \\
(0.012)\end{array}$ \\
\hline Interview year FE & Yes & Yes & Yes & Yes \\
\hline Nuts-2 FE & Yes & Yes & Yes & Yes \\
\hline R-Squared & 0.143 & 0.100 & 0.119 & 0.245 \\
\hline $\mathrm{N}$ & 1223 & 980 & 1205 & 950 \\
\hline
\end{tabular}

Note: ${ }^{*}$ significant at $10 \% ;{ }^{* *}$ significant at $5 \% ;{ }^{* * *}$ significant at $1 \%$. The standard errors are clustered on the county level and are displayed in parentheses. We pool observations from survey years 2016 to 2018 keeping only the most recent survey information. The sample is restricted to individuals with a minimum of two years of residence in Germany. Outcome variable "In employment or education" is one for refugees who report being in employment or education. Outcome variable "Full- or part-time employed" is one for refugees who report being in full- or part-time employment. Outcome "Net monthly wages" are net monthly wages, in inverse hyperbolic sine transformation. Table 6 includes the full set of covariates, as described in Section 4. For illustrative purposes, some control variables are not shown. Reference categories are as follows: primary education, aged 18-24 (aged 25-29 for full- or part-time employment), two years of residence in Germany, and Syrian origin. Information on attitudes stems from the European Social Survey. We merge natives' mean values on attitudes towards immigrants based on refugees' year of arrival and first state.9f residence in Germany. Source: IAB-BAMF-SOEP Survey of Refugees, v35 (2016-2018) and European Social Survey (2014). 


\subsection{Heterogeneity Analysis using Causal Forest}

We also look beyond the average effects to understand how the causal effects vary with observable characteristics. Unlike previous literature, we don't rely on the estimation of models by subgroups or the interaction effects as both approaches suffer from the selective choice of covariates and a lack of statistical power when a high number of parameters is included in linear regression models. Instead, to identify heterogeneous treatment effects (that is, variation in the direction and magnitude of treatment effects for individuals within a population), we use Causal Forests methodology, which provides a data-driven, less selective framework for heterogeneous treatment estimation (Athey and Imbens 2016; Athey et al. 2019).

This alternative statistical framework is based on a regression tree that systematically splits the control variable space into increasingly smaller subsets. Regression trees aim to predict an outcome variable building on the mean outcome of observations with similar characteristics. A parameter that penalizes highdimensionality reduces model complexity. The causal forest estimation combines a magnitude of regression trees to identify treatment effects, whereby each tree is defined by different orders and subsets of covariates. Similar to bootstrapping processes, variance is based on the diversity of regression trees.

Since we have two treatment variables, namely the unemployment rate and the Migrant Acceptance Index, we feed the causal forest algorithm the full set of control variables defined in Section 4 and one of the treatment variables at a time (while controlling for the other) to estimate heterogeneous treatment effects. For instance, when we consider local economic conditions as the treatment variable, the model takes the following form:

$$
\widetilde{Y_{i c t}}=\alpha_{i}\left(X_{i t}^{\prime}\right)+\tau_{i}\left(X_{i t}^{\prime}\right) U E_{c, t-2}+u_{i c t}
$$

where $\widetilde{Y_{i c t}}$ is the one of the four respective integration outcomes of refugee $i$ in county $c$ and interview year $t$, and $X_{i t}^{\prime}$ is the full set of covariates and the Migrant Acceptance Index in the first state of residence.

We first present conditional treatment effects based on 20,000 regression trees in Figure A7 where each regression tree draws a random sample of the working sample and estimates the treatment effect. We only present the results for the outcome variable being in "employment or education" for illustrative purposes but find similar patterns for the other outcome variables. ${ }^{27}$ In the absence of treatment heterogeneity, we would expect treatment effect to be clustered around the mean. However, we find the opposite, suggesting that there is considerable treatment heterogeneity. Encouragingly, the arithmetic mean is very close to the treatment effect we identified in the main analysis.

Figure A8 presents the result for the variable importance, where we set our threshold as 0.05 and above.

\footnotetext{
${ }^{27}$ The figures for the other outcome variables are available upon request.
} 
In both panels, we find that age, country of origin, education and the number of years since arrival are the important factors for treatment heterogeneity. Therefore, we only focus on these dimensions in Tables 7 and 8. The results broadly suggest that the effects of unemployment and attitudes towards immigrants are stronger for older people (that is, age 40 and above) and those with higher levels of education. The effects of the Migrant Acceptance Index are most pronounced for those with tertiary education. With respect to initial unemployment, the effects are of similar magnitude for those with secondary and tertiary education, but close to zero for refugees with primary education.

\subsection{Robustness Checks}

In this subsection, we provide additional checks that underline the robustness of the main results.

\section{Robustness to omitted variables bias}

Although we exploit the exogenous variation generated by centralized refugee allocation policy and control for various observable characteristics and fixed effects, one still might be concerned whether our results are driven by omitted unobservable factors (such as political influence in refugees' allocation across counties). To investigate this concern formally, we perform a rigorous robustness check following the method proposed by Oster (2019).

In both panels of Appendix Table A7, we first reprint the baseline estimates for our main outcomes in the top rows for comparison purposes. The second rows present the estimation bounds where we define $R_{\max }$ upper bound as 1.3 times the R-squared in specifications that control for observables following Oster (2019). ${ }^{28}$ The bottom row presents the Oster's delta, which indicates the degree of selection on unobservables relative to observables that would be needed to fully explain our results by omitted variable bias. The results presented point to a very limited movement in coefficients. High delta values also indicate that the unobservables have less effect on our coefficient of interest than the observables. Given the exogenous variation generated by the policy and wide-range of controls we include in our models, it is extremely unlikely that there are unobserved factors that are 8 to 124 times as important as all observables. Therefore, the estimates suggest that our results are unlikely to be driven by omitted-variable bias.

\footnotetext{
${ }^{28}$ Estimation bounds on the treatment effect range between the coefficient from the main specification and the coefficient estimated under the assumption that observables are as important as unobservables for the level of $R_{\max }$. $R_{\max }$ specifies the maximum R-squared that can be achieved if all unobservables were included in the regression. Oster (2019) uses a sample of 65 RCT papers to estimate an upper bound of the R-squared such that 90 percent of the results would be robust to omitted variables bias. This estimation strategy yields an upper bound for the R-squared, Rmax, that is 1.3 times the R-squared in specifications that control for observables.
} 


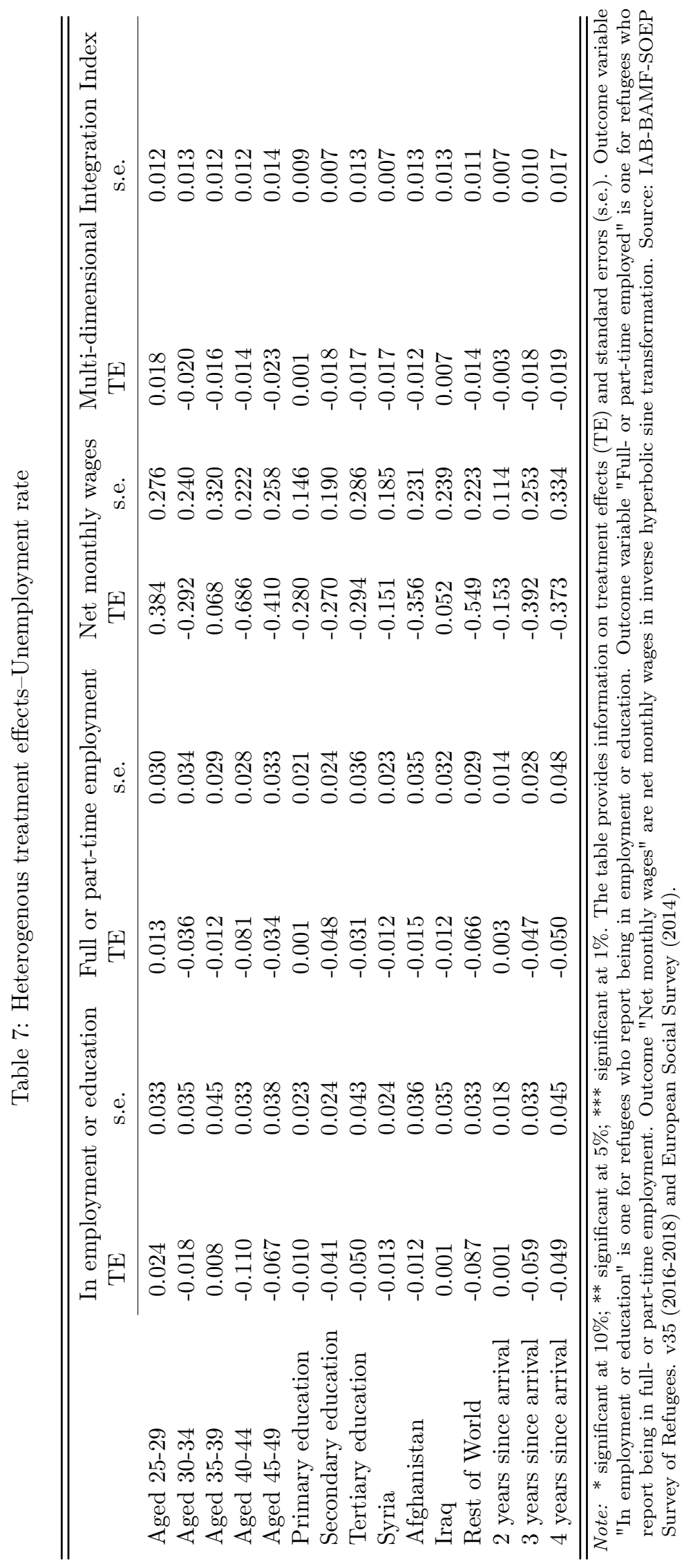




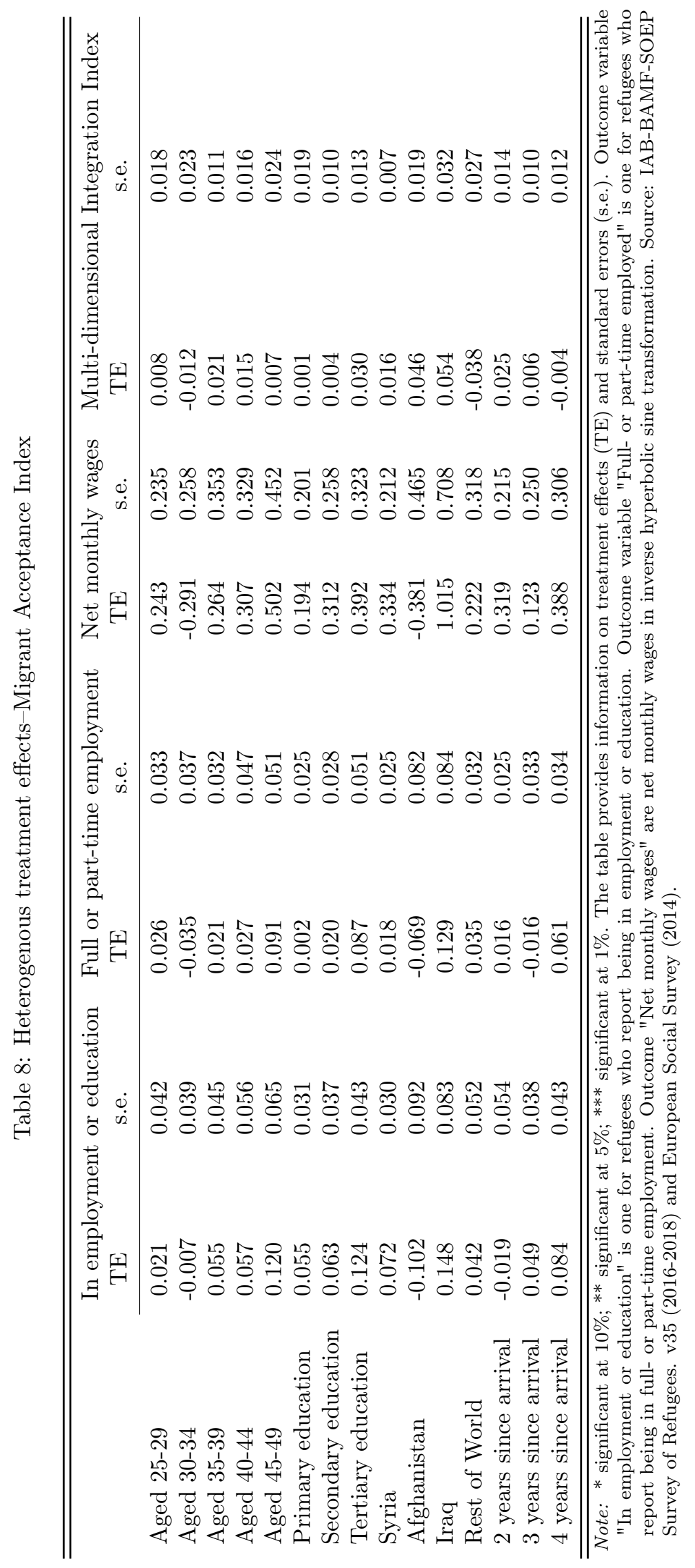




\section{Robustness to NUTS-2*year fixed effects}

We also saturate our main specification with NUTS-2*year fixed-effects, which helps us to control for all potential omitted variables (such as within-state policy change on the length of the employment ban) that can vary across NUTS-2 regions and years. The results presented in Appendix Tables A8 and A9 show that our results remain robust.

\section{Multiple hypothesis testing}

To rule out any problem related to the simultaneous inference of multiple hypotheses, we re-estimate our main results using the randomization inference technique suggested by Young (2019). This method helps us to establish the robustness of our results both for individual treatment coefficients in separate estimations and also for the null hypothesis that all treatment effects reported together are zero. The results presented in Appendix Table A10 show that our findings remain robust both for the individual coefficients and the joint tests of treatment significance.

\section{Robustness to using alternative measures of unemployment rate at the county level}

To capture the initial local economic conditions, we use county-level unemployment rate in year t-2 in our main analysis. In Appendix Figure A9, we show that our results are robust to using alternative measures of unemployment rate: one or three years before the year of interview, or one, two, or three years before the year of arrival.

\section{Robustness to using alternative measures of attitudes towards immigrants at the county level}

As explained before, due to the lack of data availability we can only measure attitudes towards migrants at the state level.

To further validate the robustness of our results, we use alternative county-level measures: the AfD vote share in 2013 and the share of respondents who reported some or big worries about immigration in 2014. Although these measures only partially capture attitudes towards migrants, the results presented in Appendix Figure A10 show that our findings remain robust.

\section{Robustness to using alternative measure of attitudes towards immigrants at the state level}

Our main specification uses information on attitudes towards immigrants at state level based on the European Social Survey data. To check if our results are sensitive to how we define the Migrant Acceptance Index, we use the readily available Diversity Index from the Gallup World Polls as an alternative measure. Similar to our main results, Appendix Table A11 suggests that both higher unemployment rate and negative attitudes towards immigrants (as measured in Gallup's Diversity Index) in the initial state of residence have a 
negative effect on refugees' labor market and social integration. While the estimates for the effect of countylevel unemployment rate are quantitatively similar, point estimates for the effect of the Diversity Index are larger.

Overall, we find robust evidence that attitudes towards immigrants-irrespective of how we measure themmatter for refugees' social and economic integration.

\section{Robustness to logit models}

In Section 5.1, we estimate linear probability models for the dichotomous outcome variables for ease of interpretation. Appendix Table A12, which reports odd ratios, illustrates that our results are qualitatively similar when we use logistic regression models.

\section{Robustness to alternative age band, 18-64}

Table A4 underlines that refugees aged $50+$ have substantially lower labor market participation rates. In our main analyses, we therefore restrict the working sample to refugees aged 18 to 49 years old in order to capture refugees most likely to be active in the labor market. ${ }^{29}$ The results presented in Appendix Table A13 show that our results remain robust when we include all adults aged 18 to 64 .

\section{Robustness to excluding counties with very few refugees}

While the representative sampling design of the SOEP maps the distribution of refugees across Germany very closely (see Section 3.1), the number of observations per county is small for some counties. As a robustness check, we calculate the number of refugees per county and exclude the least populated counties from the estimation (lowest decile; $\mathrm{N}<15$ ). Appendix Table A14 shows that our results are robust to excluding counties with small number of observations.

\section{Robustness to alternative levels of clustering and correcting for spatial correlation}

In our main specification, we cluster the standard errors at the county level. We establish robustness of our results using alternative assumptions about the variance-covariance matrix: the results are robust to clustering at gender-education-state level (assuming that residuals co-move within these units) (see Appendix Tables A15 and A16), clustering standard errors at the state level-due to small number of clusters (that is, 16 states) we also bootstrap strap standard errors-(see Appendix Tables A17 and A18) as well as correcting for spatial correlation following Conley (1999) (see Appendix Tables A19 and A20).

\footnotetext{
${ }^{29}$ We restrict the sample to refugees aged 25 to 49 when we consider being "in full- or part-time employment".
} 


\section{Robustness to excluding potentially "bad controls"}

We also checked for "bad controls" (Angrist and Pischke, 2008). One might worry that some of the individual characteristics (such as participation in an integration course) are themselves affected by initial local conditions. However, as shown in Appendix Table A21, excluding them completely does not substantively change the point estimates for our variables of interest. We keep these controls in our baseline specification to avoid omitted variable bias.

\section{Robustness to controlling for residence status}

Table A22 adds a control for residence status, using those with positive asylum decision as baseline category. We find that controlling for residence status does not affect our main results.

\section{Robustness to not controlling for NUTS-2 fixed effects}

Table A23 shows that our main results are robust to not controlling for NUTS-2 fixed effects (only exception is that Migrant Acceptance Index has no impact on multi-dimensional integration of refugees).

\section{Robustness to analyzing only states with strictest restrictions on residency}

Table A24 shows that our results remain robust if we restrict our sample to refugees living in states where residency requirement applies at the county-level, unless a refugee finds employment. This strict residency requirement applies in Bavaria, Baden-Wurttemberg, North Rhine-Westphalia, Saxony Anhalt and Saarland. The results provide additional evidence that initial conditions shape refugees' integration outcomes.

\section{Conclusion}

In this paper, we analyzed how local conditions at the time of refugees' arrival affect their short-term integration outcomes. Leveraging the variation generated by the centralized allocation policy used in Germany, we found that both high local unemployment and negative attitudes towards migrants negatively affect refugees' economic and social integration. A one standard deviation increase in county-level unemployment rate leads to a decrease of 4.3 percentage points in refugees' likelihood of being in employment or education, and a one standard deviation increase in the Migrant Acceptance Index leads to a 5.0 (4.7) percentage points increase in refugees' likelihood of being in employment or education (full- or part-time employment). Initial local unemployment has a negative, and favorable attitudes towards migrants has a positive, impact on the multi-dimensional integration of refugees. These effects are particularly driven by economic and social components, with effects of psychological, linguistic, political, and navigational components being statistically insignificant. In all cases, the results are stronger for male refugees. 
Our results highlight the importance of initial conditions for facilitating refugee integration. They also have implications for the design of refugee allocation policies. Although there is a strong political argument in favor of allocating refugees across the whole country, our results suggest that these policies come at a significant cost for subsequent integration outcomes for those refugees placed in worse performing and less welcoming regions. One possible way to address these concerns, while maintaining the principle of allocating refugees across the country, would be to change the weighting scheme to highlight even more the integration capacity of different states. One possibility for Germany would be to replace the component that is related to state population with a component related to unfilled job vacancies.

Our findings have also implications on refugee policy at the European level. Many EU member states, notably Germany, have called for a system in which asylum seekers would be reallocated across EU member states. Our findings suggest that, in addition to political difficulties (inflaming tensions between EU member states and potentially resulting in a populist backlash in those countries that are unwilling to host a larger number of asylum seekers), such a quota system could result in worse integration outcomes across the EU, as refugees placed in regions with high unemployment and negative attitudes towards immigrants would face a risk of worse subsequent economic and social integration. 


\section{References}

Ager, Alastair and Alison Strang (2008). "Understanding Integration: A Conceptual Framework". Journal of Refugee Studies 21 (2), 166-191.

Ajzenman, Nicolas, Cevat Giray Aksoy, and Sergei Guriev (2020). "Exposure to Transit Migration, Public Attitudes and Entrepreneurship". IZA Discussion Papers (13130).

Aksoy, Cevat Giray, Berkay Ozcan, and Julia Philipp (2020). "Robots and the Gender Pay Gap in Europe". IZA Discussion Papers (13842).

Aksoy, Cevat Giray and Panu Poutvaara (2019). "Refugees' and Irregular Migrants' Self-Selection into Europe: Who Migrates Where?" IZA Discussion Papers (12800).

Arendt, Jacob N., Iben Bolvig, Mette Foged, Linea Hasager, and Giovanni Peri (2020). "Integrating Refugees: Language Training or Work-first Incentives?" NBER Working Paper (w26834).

Athey, Susan and Guido Imbens (2016). "Recursive Partitioning for Heterogeneous Causal Effects". Proceedings of the National Academy of Sciences 113 (27), pp. 7353-7360.

Athey, Susan, Julie Tibshirani, and Stefan Wager (2019). "Generalized Random Forests". The Annals of Statistics 47 (2), pp. 1148-1178.

BAMF (2017). Aktuelle Zahlen zu Asyl, Ausgabe: Dezember 201\%. Tabellen, Diagramme, Erläuterungen. Tech. rep. Federal Office for Migration and Refugees.

Bansak, Kirk, Jens Hainmueller, and Dominik Hangartner (2016). "How Economic, Humanitarian, and Religious Concerns Shape European Attitudes toward Asylum Seekers". Science 354 (6309), pp. 217-222.

Barsbai, Toman, Andreas Steinmayr, and Christoph Winter (2019). "Immigration into a Recession". mimeo.

Battisti, Michele, Yvonne Giesing, and Nadzeya Laurentsyeva (2019). "Can Job Search Assistance Improve the Labour Market Integration of Refugees? Evidence from a Field Experiment". Labour Economics 61, p. 101745 .

Bauer, Thomas K., Sebastian Braun, and Michael Kvasnicka (2013). "The Economic Integration of Forced Migrants: Evidence for Post-war Germany". The Economic Journal 123 (571), pp. 998-1024.

Beaman, Lori A. (2012). "Social Networks and the Dynamics of Labour Market Outcomes: Evidence from Refugees Resettled in the US". The Review of Economic Studies 79 (1), pp. 128-161.

Becker, Sascha O. and Andreas Ferrara (2019). "Consequences of Forced Migration: A Survey of Recent Findings". Labour Economics 59, pp. 1-16.

Bellemare, Marc F. and Casey J. Wichman (2020). "Elasticities and the Inverse Hyperbolic Sine Transformation". Oxford Bulletin of Economics and Statistics 82, pp. 50-61. 
Bratsberg, Bernt, Oddbjorn Raaum, and Knut Roed (2017). "Immigrant Labor Market Integration across Admission Classes". IZA Discussion paper (10513).

Braun, Sebastian T. and Nadja Dwenger (2020). "Settlement Location Shapes the Integration of Forced Migrants: Evidence from Post-war Germany". Explorations in Economic History 77, p. 101330.

Brell, Courtney, Christian Dustmann, and Ian Preston (2020). "The Labor Market Integration of Refugee Migrants in High-income Countries". Journal of Economic Perspectives 34 (1), pp. 94-121. DOI: 10.1257/ jep.34.1.94.

Brücker, Herbert, Yuliya Kosyakova, and Eric Schuss (2020). "Integration in Arbeitsmarkt und Bildungssystem macht Fortschritte". IAB-Kurzbericht (4).

Brücker, Herbert, Nina Rother, and Jürgen Schupp (2016). "IAB-BAMF-SOEP-Befragung von Geflüchteten: Überblick und erste Ergebnisse". Politikberatung kompakt 116.

Card, David (1990). "The Impact of the Mariel Boatlift on the Miami Labor Market". ILR Review 43 (2), pp. $245-257$.

Chiswick, Barry R. and Paul W. Miller (1999). "Immigrant Earnings: Language Skills, Linguistic Concentrations and the Business Cycle". Journal of Population Economics 15 (1), pp. 31-57.

Colella, Fabrizio, Rafael Lalive, Seyhun Orcan Sakalli, and Mathias Thoenig (2019). "Inference with Arbitrary Clustering". IZA Discussion paper (12584).

Conley, Timothy G. (1999). "GMM Estimation with Cross Sectional Dependence". Journal of Econometrics $92(1)$, pp. $1-45$.

Damm, Anna P. (2009). "Ethnic Enclaves and Immigrant Labor Market Outcomes: Quasi-experimental Evidence". Journal of Labor Economics 27 (2), pp. 281-314.

DIW (2017). IAB-BAMF-SOEP-Befragung Geflüchteter in Deutschland. https://www.diw.de/de/diw_02. c.244287.de/ueber_uns/menschen_am_diw_berlin/mitarbeiter/innen.html?id=diw_01.c.538695. de. lastly downloaded on 23.10.2017, Deutsches Institut für Wirtschaftsforschung.

Edin, Per-Anders, Peter Fredriksson, and Olof Åslund (2003). "Ethnic Enclaves and the Economic Success of Immigrants-Evidence from a Natural Experiment". The Quarterly Journal of Economics 118 (1), pp. 329-357.

Edo, Anthony, Yvonne Giesing, Jonathan Öztunc, and Panu Poutvaara (2019). "Immigration and Electoral Support for the Far-left and the Far-right". European Economic Review 115, pp. 99-143.

Entorf, Horst and Martin Lange (2019). "Refugees Welcome? Understanding the Regional Heterogeneity of Anti-foreigner Hate Crimes in Germany". ZEW-Centre for European Economic Research Discussion Paper $(19-005)$. 
Facchini, Giovanni and Anna Maria Mayda (1999). "From Individual Attitudes towards Migrants to Migration Policy Outcomes: Theory and Evidence". Economic Policy 23 (56), pp. 652-713.

Falk, Armin, Andreas Kuhn, and Josef Zweimüller (2011). "Unemployment and Right-wing Extremist Crime". Scandinavian Journal of Economics 113 (2), pp. 260-285.

Fasani, Francesco, Tommaso Frattini, and Luigi Minale (2020a). "Lift the Ban? Initial Employment Restrictions and Refugee Labour Market Outcomes". CEPR Discussion Paper (14765).

- (2020b). "(The Struggle for) Refugee Integration into the Labour Market: Evidence from Europe". CEPR Discussion Paper (12718).

Getmansky, Anna, Kostas Matakos, and Tolga Sinmazdemir (2020). "Diversity without Adversity? Refugees' Efforts to Integrate Can Partially Offset Identity-based Biases". ESOC Working Papers (20).

Godøy, Anna (2017). "Local Labor Markets and Earnings of Refugee Immigrants". Empirical Economics $52(1)$, pp. $31-58$.

Goebel, Jan, Markus M Grabka, Stefan Liebig, Martin Kroh, David Richter, Carsten Schröder, and Jürgen Schupp (2019). "The German Socio-economic Panel (SOEP)". Jahrbücher für Nationalökonomie und Statistik 239 (2), pp. 345-360.

Graeber, Daniel and Felicitas Schikora (2020). "Hate Is Too Great a Burden to Bear - the Effect of Hate Crime on Refugees' Mental Health". mimeo.

Hangartner, Dominik, Marbach Moritz Dinas Elias, Konstantinos Matakos, and Dimitrios Xefteris (2019). "Does Exposure to the Refugee Crisis Make Natives More Hostile?" American Political Science Review 113 (2), pp. $442-455$.

Harder, Niklas, Lucila Figueroa, Rachel M. Gillum, Dominik Hangartner, David D. Laitin, and Jens Hainmueller (2018). "Multidimensional Measure of Immigrant Integration". Proceedings of the National Academy of Sciences 115 (45), pp. 11483-11488.

Joyce, Patrick (2019). "Labor Market Integration of Refugees in Scandinavia after 2015". Ratio Working Paper (319).

Krueger, Alan B. and Jörn-Steffen Pischke (1997). "A Statistical Analysis of Crime against Foreigners in Unified Germany". Journal of Human Resources 32, pp. 182-209.

Marbach, Moritz, Dominik Hangartner, and Jens Hainmueller (2018). "The Long-term Impact of Employment Bans on the Economic Integration of Refugees". Science Advances 4 (9), pp. 1-6.

Martén, Linna, Jens Hainmueller, and Dominik Hangartner (2019). "Ethnic Networks Can Foster the Economic Integration of Refugees". Proceedings of the National Academy of Sciences 116 (33), pp. 1628016285 . 
Massumi, Mona, Nora von Dewitz, Johanna Grießbach, Henrike Terhart, Katarina Wagner, Kathrin Hippmann, Lale Altinay, Mit Michael Becker-Mrotzek, and Hans-Joachim Roth (2015). "Neu zugewanderte Kinder und Jugendliche im deutschen Schulsystem". Köln: Mercator-Institut für Sprachförderung und Deutsch als Zweitsprache und Zentrum für LehrerInnenbildung der Universität zu Köln.

Matakos, Kostas, Riikka Savolainen, and Janne Tukiainen (2020). "Refugee Migration and the Politics of Redistribution: Do Supply and Demand Meet?" Aboa Center for Economics Discussion Papers (132).

Oster, Emily (2019). "Unobservable Selection and Coefficient Stability: Theory and Evidence". Journal of Business Economic Statistics 37 (2), pp. 187-204.

Otto, Alkis H. and Max F. Steinhardt (2014). "Immigration and Election Outcomes - Evidence from City Districts in Hamburg". Regional Science and Urban Economics 45, pp. 67-79.

Poutvaara, Panu and Max F. Steinhardt (2018). "Bitterness in Life and Attitudes towards Immigration". European Journal of Political Economy 55, pp. 471-490.

Ruiz, Isabel and Carlos Vargas-Silva (2018). "Differences in Labour Market Outcomes between Natives, Refugees and Other Migrants in the UK". Journal of Economic Geography 18 (4), pp. 855-885.

Sachverständigenrat deutscher Stiftungen für Integration und Migration (2017). Chancen in der Krise: Zur Zukunft der Flüchtlingspolitik in Deutschland und Europa. Tech. rep. SVR.

Sarvimäki, Matti (2017). "Labor Market Integration of Refugees in Finland". Nordic Economic Policy Review 7 (1), pp. 91-114.

Schultz-Nielsen, Marie L. (2017). "Labour Market Integration of Refugees in Denmark". Nordic Economic Policy Review 7, pp. 55-90.

Strang, Alison and Alastair Ager (2010). "Refugee Integration: Emerging Trends and Remaining Agendas". Journal of Refugee Studies 23 (4), pp. 589-607.

Young, Alwyn (2019). "Channeling Fisher: Randomization Tests and the Statistical Insignificance of Seemingly Significant Experimental Results". The Quarterly Journal of Economics 134 (2), pp. 557-598.

Åslund, Olof and Dan-Olof Rooth (2007). "Do When and Where Matter? Initial Labour Market Conditions and Immigrant Earnings". The Economic Journal 117 (518), pp. 422-448. 
A Appendix Tables 


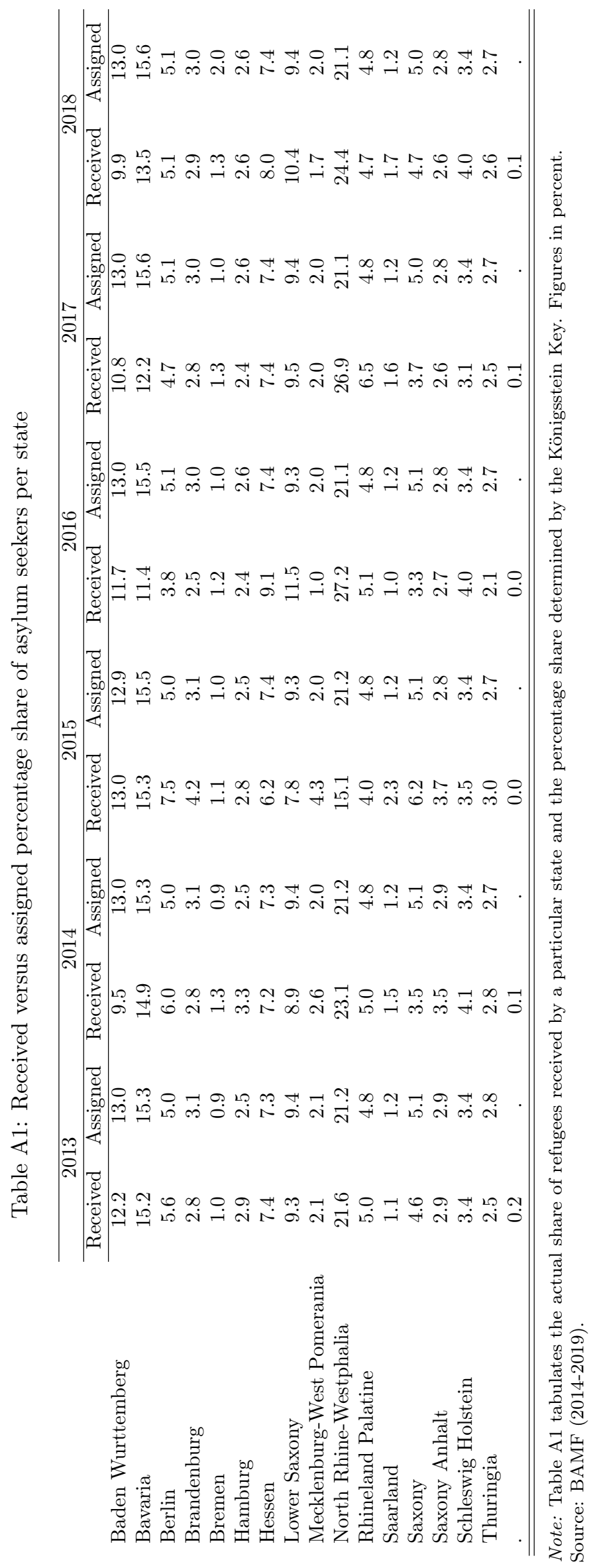


Table A2: Main activities by year since arrival in Germany, adults aged 18-49

\begin{tabular}{|c|c|c|c|c|c|c|}
\hline & $\begin{array}{c}(1) \\
\text { Total }\end{array}$ & $\begin{array}{c}(2) \\
1 \text { year ago }\end{array}$ & $\begin{array}{c}(3) \\
2 \text { years ago }\end{array}$ & $\begin{array}{c}(4) \\
3 \text { years ago }\end{array}$ & $\begin{array}{c}(5) \\
4 \text { years ago }\end{array}$ & $\begin{array}{c}(6) \\
5 \text { years ago }\end{array}$ \\
\hline \multicolumn{7}{|l|}{ Panel A - Full sample } \\
\hline \multirow{2}{*}{$\begin{array}{l}\text { School or } \\
\text { university }\end{array}$} & 0.023 & 0.011 & 0.023 & 0.028 & 0.024 & 0.021 \\
\hline & $(0.151)$ & $(0.105)$ & $(0.150)$ & $(0.166)$ & $(0.152)$ & $(0.145)$ \\
\hline \multirow[t]{2}{*}{ Vocational training } & 0.028 & 0.004 & 0.015 & 0.032 & 0.061 & 0.073 \\
\hline & $(0.164)$ & $(0.063)$ & $(0.122)$ & $(0.175)$ & $(0.240)$ & $(0.260)$ \\
\hline \multirow[t]{2}{*}{ Employed full-time } & 0.101 & 0.015 & 0.051 & 0.136 & 0.195 & 0.141 \\
\hline & $(0.301)$ & $(0.122)$ & $(0.220)$ & $(0.343)$ & $(0.396)$ & $(0.349)$ \\
\hline \multirow[t]{2}{*}{ Employed part-time } & 0.096 & 0.038 & 0.076 & 0.109 & 0.156 & 0.141 \\
\hline & $(0.294)$ & $(0.192)$ & $(0.266)$ & $(0.312)$ & $(0.363)$ & $(0.349)$ \\
\hline \multirow{2}{*}{$\begin{array}{l}\text { Not in employment } \\
\text { or training }\end{array}$} & 0.606 & 0.732 & 0.640 & 0.569 & 0.498 & 0.560 \\
\hline & $(0.489)$ & $(0.443)$ & $(0.480)$ & $(0.495)$ & $(0.500)$ & $(0.497)$ \\
\hline \multirow{2}{*}{$\begin{array}{c}\text { Unemployed \& } \\
\text { integration course }\end{array}$} & 0.147 & 0.200 & 0.195 & 0.125 & 0.067 & 0.064 \\
\hline & $(0.354)$ & $(0.400)$ & $(0.396)$ & $(0.331)$ & $(0.250)$ & $(0.245)$ \\
\hline $\mathrm{N}$ & 6188 & 996 & 1652 & 2587 & 719 & 234 \\
\hline \multicolumn{7}{|l|}{ Panel B - Males } \\
\hline \multirow[t]{2}{*}{$\begin{array}{l}\text { School or } \\
\text { university }\end{array}$} & 0.024 & 0.012 & 0.023 & 0.028 & 0.023 & 0.031 \\
\hline & $(0.152)$ & $(0.110)$ & $(0.149)$ & $(0.164)$ & $(0.149)$ & $(0.173)$ \\
\hline \multirow[t]{2}{*}{ Vocational training } & 0.040 & 0.005 & 0.024 & 0.043 & 0.086 & 0.100 \\
\hline & $(0.195)$ & $(0.073)$ & $(0.152)$ & $(0.203)$ & $(0.281)$ & $(0.301)$ \\
\hline \multirow[t]{2}{*}{ Employed full-time } & 0.162 & 0.026 & 0.085 & 0.210 & 0.302 & 0.238 \\
\hline & $(0.369)$ & $(0.160)$ & $(0.279)$ & $(0.407)$ & $(0.459)$ & $(0.428)$ \\
\hline \multirow[t]{2}{*}{ Employed part-time } & 0.122 & 0.053 & 0.101 & 0.139 & 0.177 & 0.169 \\
\hline & $(0.327)$ & $(0.224)$ & $(0.302)$ & $(0.346)$ & $(0.382)$ & $(0.376)$ \\
\hline \multirow{2}{*}{$\begin{array}{l}\text { Not in employment } \\
\text { or training }\end{array}$} & 0.504 & 0.674 & 0.557 & 0.462 & 0.356 & 0.423 \\
\hline & $(0.500)$ & $(0.469)$ & $(0.497)$ & $(0.499)$ & $(0.479)$ & $(0.496)$ \\
\hline \multirow{2}{*}{$\begin{array}{l}\text { Unemployed \& } \\
\text { integration course }\end{array}$} & 0.148 & 0.229 & 0.210 & 0.119 & 0.057 & 0.038 \\
\hline & $(0.356)$ & $(0.420)$ & $(0.408)$ & $(0.324)$ & $(0.232)$ & $(0.193)$ \\
\hline $\mathrm{N}$ & 3692 & 568 & 928 & 1625 & 441 & 130 \\
\hline \multicolumn{7}{|l|}{ Panel $C$-Females } \\
\hline \multirow{2}{*}{$\begin{array}{l}\text { School or } \\
\text { university }\end{array}$} & 0.023 & 0.009 & 0.023 & 0.029 & 0.025 & 0.010 \\
\hline & $(0.149)$ & $(0.096)$ & $(0.152)$ & $(0.168)$ & $(0.157)$ & $(0.098)$ \\
\hline \multirow[t]{2}{*}{ Vocational training } & 0.010 & 0.002 & 0.004 & 0.012 & 0.022 & 0.038 \\
\hline & $(0.102)$ & $(0.048)$ & $(0.064)$ & $(0.111)$ & $(0.146)$ & $(0.193)$ \\
\hline \multirow[t]{2}{*}{ Employed full-time } & 0.010 & 0.000 & 0.007 & 0.012 & 0.025 & 0.019 \\
\hline & $(0.102)$ & $(0.000)$ & $(0.083)$ & $(0.111)$ & $(0.157)$ & $(0.138)$ \\
\hline \multirow[t]{2}{*}{ Employed part-time } & 0.056 & 0.019 & 0.044 & 0.058 & 0.122 & 0.106 \\
\hline & $(0.231)$ & $(0.136)$ & $(0.206)$ & $(0.234)$ & $(0.328)$ & $(0.309)$ \\
\hline \multirow{2}{*}{$\begin{array}{l}\text { Not in employment } \\
\text { or training }\end{array}$} & 0.756 & 0.808 & 0.746 & 0.752 & 0.723 & 0.731 \\
\hline & $(0.430)$ & $(0.394)$ & $(0.436)$ & $(0.432)$ & $(0.448)$ & $(0.446)$ \\
\hline \multirow{2}{*}{$\begin{array}{c}\text { Unemployed \& } \\
\text { integration course }\end{array}$} & 0.144 & 0.161 & 0.175 & 0.136 & 0.083 & 0.096 \\
\hline & $(0.351)$ & $(0.368)$ & $(0.381)$ & $(0.343)$ & $(0.276)$ & $(0.296)$ \\
\hline $\mathrm{N}$ & 2496 & 428 & 724 & 962 & 278 & 104 \\
\hline
\end{tabular}


Table A3: Main activities by year since arrival in Germany, single refugees without children aged 18-49

\begin{tabular}{|c|c|c|c|c|c|c|}
\hline & $\begin{array}{c}(1) \\
\text { Total }\end{array}$ & $\begin{array}{c}(2) \\
1 \text { year ago }\end{array}$ & $\begin{array}{c}(3) \\
2 \text { years ago }\end{array}$ & $\begin{array}{c}(4) \\
3 \text { years ago }\end{array}$ & $\begin{array}{c}(5) \\
4 \text { years ago }\end{array}$ & $\begin{array}{c}(6) \\
5 \text { years ago }\end{array}$ \\
\hline \multicolumn{7}{|l|}{ Panel A - Males } \\
\hline \multirow[t]{2}{*}{$\begin{array}{l}\text { School or } \\
\text { university }\end{array}$} & 0.048 & 0.023 & 0.048 & 0.057 & 0.051 & 0.077 \\
\hline & $(0.215)$ & $(0.149)$ & $(0.213)$ & $(0.232)$ & $(0.220)$ & $(0.269)$ \\
\hline \multirow[t]{2}{*}{ Vocational training } & 0.068 & 0.010 & 0.041 & 0.077 & 0.169 & 0.154 \\
\hline & $(0.251)$ & $(0.098)$ & $(0.198)$ & $(0.267)$ & $(0.376)$ & $(0.364)$ \\
\hline \multirow[t]{2}{*}{ Employed full-time } & 0.164 & 0.016 & 0.084 & 0.235 & 0.311 & 0.231 \\
\hline & $(0.370)$ & $(0.127)$ & $(0.277)$ & $(0.424)$ & $(0.464)$ & $(0.425)$ \\
\hline \multirow[t]{2}{*}{ Employed part-time } & 0.124 & 0.055 & 0.117 & 0.156 & 0.136 & 0.135 \\
\hline & $(0.330)$ & $(0.229)$ & $(0.322)$ & $(0.363)$ & $(0.343)$ & $(0.345)$ \\
\hline \multirow{2}{*}{$\begin{array}{l}\text { Not in employment } \\
\text { or training }\end{array}$} & 0.491 & 0.672 & 0.575 & 0.415 & 0.299 & 0.404 \\
\hline & $(0.500)$ & $(0.470)$ & $(0.495)$ & $(0.493)$ & $(0.459)$ & $(0.495)$ \\
\hline \multirow{2}{*}{$\begin{array}{l}\text { Unemployed \& } \\
\text { integration course }\end{array}$} & 0.105 & 0.224 & 0.136 & 0.060 & 0.034 & 0.000 \\
\hline & $(0.307)$ & $(0.418)$ & $(0.343)$ & $(0.238)$ & $(0.181)$ & $(0.000)$ \\
\hline $\mathrm{N}$ & 1655 & 308 & 419 & 699 & 177 & 52 \\
\hline \multicolumn{7}{|l|}{ Panel B - Females } \\
\hline \multirow[t]{2}{*}{$\begin{array}{l}\text { School or } \\
\text { university }\end{array}$} & 0.097 & 0.038 & 0.105 & 0.141 & 0.057 & 0.000 \\
\hline & $(0.296)$ & $(0.192)$ & $(0.307)$ & $(0.349)$ & $(0.233)$ & $(0.000)$ \\
\hline \multirow[t]{2}{*}{ Vocational training } & 0.033 & 0.013 & 0.007 & 0.031 & 0.075 & 0.267 \\
\hline & $(0.179)$ & $(0.113)$ & $(0.084)$ & $(0.173)$ & $(0.267)$ & $(0.458)$ \\
\hline \multirow[t]{2}{*}{ Employed full-time } & 0.026 & 0.000 & 0.000 & 0.049 & 0.057 & 0.067 \\
\hline & $(0.161)$ & $(0.000)$ & $(0.000)$ & $(0.217)$ & $(0.233)$ & $(0.258)$ \\
\hline \multirow[t]{2}{*}{ Employed part-time } & 0.099 & 0.051 & 0.063 & 0.110 & 0.226 & 0.133 \\
\hline & $(0.299)$ & $(0.221)$ & $(0.244)$ & $(0.314)$ & $(0.423)$ & $(0.352)$ \\
\hline \multirow{2}{*}{$\begin{array}{l}\text { Not in employment } \\
\quad \text { or training }\end{array}$} & 0.618 & 0.633 & 0.671 & 0.595 & 0.547 & 0.533 \\
\hline & $(0.486)$ & $(0.485)$ & $(0.471)$ & $(0.492)$ & $(0.503)$ & $(0.516)$ \\
\hline \multirow[t]{2}{*}{$\begin{array}{c}\text { Unemployed \& } \\
\text { integration course }\end{array}$} & 0.126 & 0.266 & 0.154 & 0.074 & 0.038 & 0.000 \\
\hline & $(0.332)$ & $(0.445)$ & $(0.362)$ & $(0.262)$ & $(0.192)$ & $(0.000)$ \\
\hline $\mathrm{N}$ & 453 & 79 & 143 & 163 & 53 & 15 \\
\hline
\end{tabular}


Table A4: Main activities by year since arrival in Germany for different age groups

\begin{tabular}{|c|c|c|c|c|c|c|}
\hline & $\begin{array}{c}(1) \\
\text { Total }\end{array}$ & $\begin{array}{c}(2) \\
1 \text { year ago }\end{array}$ & $\begin{array}{c}(3) \\
2 \text { years ago }\end{array}$ & $\begin{array}{c}(4) \\
3 \text { years ago }\end{array}$ & $\begin{array}{c}(5) \\
4 \text { years ago }\end{array}$ & $\begin{array}{c}(6) \\
5 \text { years ago }\end{array}$ \\
\hline \multicolumn{7}{|l|}{ Panel A - Aged 18-24 } \\
\hline \multirow[t]{2}{*}{$\begin{array}{l}\text { School or } \\
\text { university }\end{array}$} & 0.070 & 0.028 & 0.070 & 0.091 & 0.070 & 0.100 \\
\hline & $(0.255)$ & $(0.164)$ & $(0.256)$ & $(0.288)$ & $(0.256)$ & $(0.304)$ \\
\hline Vocational training & $\begin{array}{c}0.059 \\
(0.235)\end{array}$ & $\begin{array}{c}0.009 \\
(0.096)\end{array}$ & $\begin{array}{c}0.031 \\
(0.173)\end{array}$ & $\begin{array}{c}0.071 \\
(0.257)\end{array}$ & $\begin{array}{c}0.154 \\
(0.362)\end{array}$ & $\begin{array}{c}0.275 \\
(0.452)\end{array}$ \\
\hline Employed full-time & $\begin{array}{c}0.085 \\
(0.278)\end{array}$ & $\begin{array}{c}0.015 \\
(0.123)\end{array}$ & $\begin{array}{c}0.041 \\
(0.199)\end{array}$ & $\begin{array}{c}0.137 \\
(0.345)\end{array}$ & $\begin{array}{c}0.168 \\
(0.375)\end{array}$ & $\begin{array}{c}0.075 \\
(0.267)\end{array}$ \\
\hline Employed part-time & $\begin{array}{c}0.099 \\
(0.299)\end{array}$ & $\begin{array}{c}0.034 \\
(0.181)\end{array}$ & $\begin{array}{c}0.085 \\
(0.279)\end{array}$ & $\begin{array}{c}0.134 \\
(0.341)\end{array}$ & $\begin{array}{c}0.140 \\
(0.348)\end{array}$ & $\begin{array}{c}0.125 \\
(0.335)\end{array}$ \\
\hline \multirow{2}{*}{$\begin{array}{l}\text { Not in employment } \\
\text { or training }\end{array}$} & 0.576 & 0.715 & 0.626 & 0.508 & 0.420 & 0.425 \\
\hline & $(0.494)$ & $(0.452)$ & $(0.484)$ & $(0.500)$ & $(0.495)$ & $(0.501)$ \\
\hline \multirow{2}{*}{$\begin{array}{l}\text { Unemployed \& } \\
\text { integration course }\end{array}$} & 0.111 & 0.199 & 0.147 & 0.058 & 0.049 & 0.000 \\
\hline & $(0.315)$ & $(0.400)$ & $(0.354)$ & $(0.234)$ & $(0.217)$ & $(0.000)$ \\
\hline $\mathrm{N}$ & 1597 & 326 & 484 & 604 & 143 & 40 \\
\hline \multicolumn{7}{|l|}{ Panel B - Aged 25-49 } \\
\hline \multirow[t]{2}{*}{$\begin{array}{l}\text { School or } \\
\text { university }\end{array}$} & 0.007 & 0.003 & 0.003 & 0.009 & 0.012 & 0.005 \\
\hline & $(0.083)$ & $(0.055)$ & $(0.058)$ & $(0.095)$ & $(0.110)$ & $(0.072)$ \\
\hline Vocational training & $\begin{array}{c}0.017 \\
(0.129)\end{array}$ & $\begin{array}{c}0.001 \\
(0.039)\end{array}$ & $\begin{array}{c}0.009 \\
(0.092)\end{array}$ & $\begin{array}{c}0.020 \\
(0.139)\end{array}$ & $\begin{array}{c}0.038 \\
(0.192)\end{array}$ & $\begin{array}{c}0.031 \\
(0.174)\end{array}$ \\
\hline Employed full-time & $\begin{array}{c}0.107 \\
(0.309)\end{array}$ & $\begin{array}{c}0.015 \\
(0.121)\end{array}$ & $\begin{array}{c}0.055 \\
(0.228)\end{array}$ & $\begin{array}{c}0.136 \\
(0.343)\end{array}$ & $\begin{array}{c}0.201 \\
(0.401)\end{array}$ & $\begin{array}{c}0.155 \\
(0.362)\end{array}$ \\
\hline Employed part-time & $\begin{array}{c}0.094 \\
(0.292)\end{array}$ & $\begin{array}{l}0.040 \\
(0.197)\end{array}$ & $\begin{array}{c}0.073 \\
(0.260)\end{array}$ & $\begin{array}{c}0.101 \\
(0.302)\end{array}$ & $\begin{array}{c}0.160 \\
(0.367)\end{array}$ & $\begin{array}{c}0.144 \\
(0.352)\end{array}$ \\
\hline \multirow[t]{2}{*}{$\begin{array}{l}\text { Not in employment } \\
\text { or training }\end{array}$} & 0.616 & 0.740 & 0.646 & 0.588 & 0.517 & 0.588 \\
\hline & $(0.486)$ & $(0.439)$ & $(0.479)$ & $(0.492)$ & $(0.500)$ & $(0.494)$ \\
\hline \multirow[t]{2}{*}{$\begin{array}{l}\text { Unemployed \& } \\
\text { integration course }\end{array}$} & 0.159 & 0.200 & 0.215 & 0.146 & 0.071 & 0.077 \\
\hline & $(0.366)$ & $(0.400)$ & $(0.411)$ & $(0.353)$ & $(0.257)$ & $(0.268)$ \\
\hline $\mathrm{N}$ & 4591 & 670 & 1168 & 1983 & 576 & 194 \\
\hline \multicolumn{7}{|l|}{ Panel C - Aged $50+$} \\
\hline \multirow[t]{2}{*}{$\begin{array}{l}\text { School or } \\
\text { university }\end{array}$} & 0.002 & 0.000 & 0.000 & 0.004 & 0.000 & 0.000 \\
\hline & $(0.041)$ & $(0.000)$ & $(0.000)$ & $(0.063)$ & $(0.000)$ & $(0.000)$ \\
\hline Vocational training & $\begin{array}{c}0.000 \\
(0.000)\end{array}$ & $\begin{array}{c}0.000 \\
(0.000)\end{array}$ & $\begin{array}{c}0.000 \\
(0.000)\end{array}$ & $\begin{array}{c}0.000 \\
(0.000)\end{array}$ & $\begin{array}{c}0.000 \\
(0.000)\end{array}$ & $\begin{array}{c}0.000 \\
(0.000)\end{array}$ \\
\hline Employed full-time & $\begin{array}{c}0.022 \\
(0.145)\end{array}$ & $\begin{array}{c}0.011 \\
(0.104)\end{array}$ & $\begin{array}{c}0.007 \\
(0.082)\end{array}$ & $\begin{array}{c}0.016 \\
(0.125)\end{array}$ & $\begin{array}{c}0.071 \\
(0.259)\end{array}$ & $\begin{array}{c}0.038 \\
(0.196)\end{array}$ \\
\hline Employed part-time & $\begin{array}{c}0.065 \\
(0.246)\end{array}$ & $\begin{array}{c}0.011 \\
(0.104)\end{array}$ & $\begin{array}{c}0.027 \\
(0.163)\end{array}$ & $\begin{array}{c}0.063 \\
(0.243)\end{array}$ & $\begin{array}{c}0.119 \\
(0.326)\end{array}$ & $\begin{array}{c}0.308 \\
(0.471)\end{array}$ \\
\hline \multirow{2}{*}{$\begin{array}{l}\text { Not in employment } \\
\text { or training }\end{array}$} & 0.733 & 0.761 & 0.755 & 0.740 & 0.690 & 0.577 \\
\hline & $(0.443)$ & $(0.429)$ & $(0.431)$ & $(0.439)$ & $(0.465)$ & $(0.504)$ \\
\hline \multirow{2}{*}{$\begin{array}{l}\text { Unemployed \& } \\
\text { integration course }\end{array}$} & 0.179 & 0.217 & 0.211 & 0.177 & 0.119 & 0.077 \\
\hline & $(0.384)$ & $(0.415)$ & $(0.409)$ & $(0.383)$ & $(0.326)$ & $(0.272)$ \\
\hline $\mathrm{N}$ & 603 & 92 & 147 & 254 & 84 & 26 \\
\hline
\end{tabular}


Table A5: Determinants of refugees' labor market outcomes, including the full set of covariates

\begin{tabular}{|c|c|c|c|c|}
\hline & $\begin{array}{c}(1) \\
\text { In employment } \\
\text { or education } \\
\text { b/se }\end{array}$ & $\begin{array}{c}(2) \\
\text { Full or } \\
\text { part-time } \\
\text { b/se }\end{array}$ & $\begin{array}{c}(3) \\
\text { Net monthly wages } \\
\mathrm{b} / \mathrm{se}\end{array}$ & $\begin{array}{c}(4) \\
\text { Multi-dimensional } \\
\text { Integration Index } \\
\mathrm{b} / \mathrm{se}\end{array}$ \\
\hline Unemployment rate t-2 std. & $\begin{array}{l}-0.043^{* * *} \\
(0.013)\end{array}$ & $\begin{array}{l}-0.042^{* * *} \\
(0.012)\end{array}$ & $\begin{array}{l}-0.341^{* * *} \\
(0.084)\end{array}$ & $\begin{array}{l}-0.014 * * \\
(0.007)\end{array}$ \\
\hline Migrant Acceptance Index std. & $\begin{array}{l}0.050^{* * *} \\
(0.016)\end{array}$ & $\begin{array}{l}0.047^{* * *} \\
(0.013)\end{array}$ & $\begin{array}{c}0.178^{*} \\
(0.092)\end{array}$ & $\begin{array}{r}0.011^{*} \\
(0.006)\end{array}$ \\
\hline Female & $\begin{array}{l}-0.196^{* * *} \\
(0.014)\end{array}$ & $\begin{array}{l}-0.174^{* * *} \\
(0.013)\end{array}$ & $\begin{array}{l}-1.286^{* * *} \\
(0.093)\end{array}$ & $\begin{array}{l}-0.081^{* * *} \\
(0.005)\end{array}$ \\
\hline Secondary education & $\begin{array}{l}0.039^{* *} \\
(0.015)\end{array}$ & $\begin{array}{c}0.021 \\
(0.015)\end{array}$ & $\begin{array}{c}0.114 \\
(0.107)\end{array}$ & $\begin{array}{l}0.040^{* * *} \\
(0.007)\end{array}$ \\
\hline Tertiary education & $\begin{array}{l}0.061^{* * *} \\
(0.021)\end{array}$ & $\begin{array}{l}0.049^{* *} \\
(0.021)\end{array}$ & $\begin{array}{l}0.391^{* *} \\
(0.152)\end{array}$ & $\begin{array}{l}0.065^{* * *} \\
(0.010)\end{array}$ \\
\hline Participated in integration course & $\begin{array}{c}0.002 \\
(0.018)\end{array}$ & $\begin{array}{l}-0.007 \\
(0.016)\end{array}$ & $\begin{array}{l}-0.004 \\
(0.112)\end{array}$ & $\begin{array}{l}0.041^{* * *} \\
(0.006)\end{array}$ \\
\hline German skills before emigration & $\begin{array}{c}0.051 \\
(0.048)\end{array}$ & $\begin{array}{l}-0.009 \\
(0.041)\end{array}$ & $\begin{array}{c}0.200 \\
(0.370)\end{array}$ & $\begin{array}{l}0.072^{* * * *} \\
(0.017)\end{array}$ \\
\hline Help finding a job & $\begin{array}{l}0.179^{* * *} \\
(0.023)\end{array}$ & $\begin{array}{l}0.133^{* * *} \\
(0.022)\end{array}$ & $\begin{array}{l}1.357^{* * *} \\
(0.180)\end{array}$ & \\
\hline $\begin{array}{l}\text { Support from family \& friends } \\
\text { before emigration }\end{array}$ & -0.028 & -0.018 & $-0.271^{* *}$ & 0.002 \\
\hline & $(0.018)$ & $(0.018)$ & $(0.127)$ & $(0.007)$ \\
\hline Children in household & $\begin{array}{l}-0.074^{* * *} \\
(0.019)\end{array}$ & $\begin{array}{l}-0.075^{* * *} \\
(0.019)\end{array}$ & $\begin{array}{l}-0.604^{* * *} \\
(0.138)\end{array}$ & $\begin{array}{l}0.003 \\
(0.009)\end{array}$ \\
\hline Afghan origin & $\begin{array}{l}-0.015 \\
(0.023)\end{array}$ & $\begin{array}{l}-0.014 \\
(0.024)\end{array}$ & $\begin{array}{l}-0.256 \\
(0.157)\end{array}$ & $\begin{array}{l}-0.008 \\
(0.009)\end{array}$ \\
\hline Iraqi origin & $\begin{array}{l}-0.107^{* * *} \\
(0.022)\end{array}$ & $\begin{array}{l}-0.072^{* * *} \\
(0.021)\end{array}$ & $\begin{array}{l}-0.575^{* * *} \\
(0.145)\end{array}$ & $\begin{array}{l}-0.022^{* *} \\
(0.010)\end{array}$ \\
\hline Other origin & $\begin{array}{l}-0.006 \\
(0.024)\end{array}$ & $\begin{array}{l}-0.009 \\
(0.021)\end{array}$ & $\begin{array}{c}0.101 \\
(0.172)\end{array}$ & $\begin{array}{l}-0.018^{*} \\
(0.010)\end{array}$ \\
\hline 3 years of residence in Germany & $\begin{array}{l}0.121^{* * *} \\
(0.018)\end{array}$ & $\begin{array}{l}0.087^{* * * *} \\
(0.017)\end{array}$ & $\begin{array}{l}0.779^{* * * *} \\
(0.130)\end{array}$ & $\begin{array}{l}0.034^{* * * *} \\
(0.008)\end{array}$ \\
\hline 4 years of residence in Germany & $\begin{array}{l}0.227^{* * *} \\
(0.027)\end{array}$ & $\begin{array}{l}0.169^{* * *} \\
(0.028)\end{array}$ & $\begin{array}{l}1.495^{* * *} \\
(0.202)\end{array}$ & $\begin{array}{l}0.070^{* * *} \\
(0.011)\end{array}$ \\
\hline Living in West Germany & $\begin{array}{l}-0.085^{* * *} \\
(0.007)\end{array}$ & $\begin{array}{l}-0.068^{* * *} \\
(0.008)\end{array}$ & $\begin{array}{l}-0.890^{* * *} \\
(0.044)\end{array}$ & $\begin{array}{l}-0.008^{* *} \\
(0.003)\end{array}$ \\
\hline Married/ In partnership & $\begin{array}{l}-0.044^{* *} \\
(0.021)\end{array}$ & $\begin{array}{c}0.017 \\
(0.023)\end{array}$ & $\begin{array}{c}0.051 \\
(0.151)\end{array}$ & $\begin{array}{l}-0.024^{* * *} \\
(0.008)\end{array}$ \\
\hline Satisfactory health status & $\begin{array}{l}0.061^{* * *} \\
(0.021)\end{array}$ & $\begin{array}{l}0.053^{* * *} \\
(0.017)\end{array}$ & $\begin{array}{l}0.277^{* *} \\
(0.129)\end{array}$ & $\begin{array}{l}0.044^{* * *} \\
(0.010)\end{array}$ \\
\hline Share of Syrians at county level in 2014 & $\begin{array}{c}4.744 \\
(11.972)\end{array}$ & $\begin{array}{c}5.462 \\
(11.157)\end{array}$ & $\begin{array}{c}46.154 \\
(82.288)\end{array}$ & $\begin{array}{l}-4.692 \\
(6.463)\end{array}$ \\
\hline Share of Afghans at county level in 2014 & $\begin{array}{c}5.952 \\
(20.956)\end{array}$ & $\begin{array}{c}40.448^{* *} \\
(19.295)\end{array}$ & $\begin{array}{l}313.214^{* *} \\
(132.821)\end{array}$ & $\begin{array}{c}27.655^{* *} \\
(11.155)\end{array}$ \\
\hline Share of Iraqis at county level in 2014 & $\begin{array}{l}10.621 \\
(7.793)\end{array}$ & $\begin{array}{c}8.326 \\
(7.254)\end{array}$ & $\begin{array}{c}21.187 \\
(51.307)\end{array}$ & $\begin{array}{l}-0.477 \\
(4.680)\end{array}$ \\
\hline Interview year FE & Yes & Yes & Yes & Yes \\
\hline Nuts-2 FE & Yes & Yes & Yes & Yes \\
\hline Age group FE & Yes & Yes & Yes & Yes \\
\hline Religion FE & Yes & Yes & Yes & Yes \\
\hline R-Squared & 0.229 & 0.205 & 0.228 & 0.253 \\
\hline $\mathrm{N}$ & 3170 & 2434 & 3013 & 2477 \\
\hline
\end{tabular}

Note: ${ }^{*}$ significant at $10 \% ;{ }^{* *}$ significant at $5 \% ;{ }^{* * *}$ significant at $1 \%$. The standard levels are clustered on the county level and are displayed in parentheses. We pool observations from survey years 2016 to 2018 keeping only the most recent survey information. The sample is restricted to individuals with a minimum of two years of residence in Germany. Outcome variable "In employment or education" is one for refugees who report being in employment or education. Outcome variable "Full- or part-time employed" is one for refugees who report being in full- or part-time employment. Outcome "Net monthly wages" are net monthly wages, in inverse hyperbolic sine transformation. Reference categories are as follows: primary education, aged 18-24 (aged 25-29 for full- or part-time employment), two years of residence in Germany, and Syrian origin. Information on attitudes stems from the European Social Survey. We mqqge natives' mean values on attitudes towards immigrants based on refugees' year of arrival and first state of residence in Germany. Source: IAB-BAMF-SOEP Survey of Refugees, v35 (2016-2018) and European Social Survey (2014). 
Table A6: Effect of unemployment and attitudes towards immigrants on the dimensions of the Multidimensional Integration Index, by gender

\begin{tabular}{|c|c|c|c|c|c|c|}
\hline & $\begin{array}{c}(1) \\
\text { Psychological } \\
\text { b/se }\end{array}$ & $\begin{array}{c}(2) \\
\text { Linguistic } \\
\text { b/se }\end{array}$ & $\begin{array}{c}(3) \\
\text { Economic } \\
\mathrm{b} / \mathrm{se}\end{array}$ & $\begin{array}{c}(4) \\
\text { Political } \\
\text { b/se }\end{array}$ & $\begin{array}{c}(5) \\
\text { Social } \\
\mathrm{b} / \mathrm{se} \\
\end{array}$ & $\begin{array}{c}(6) \\
\text { Navigationa } \\
\mathrm{b} / \mathrm{se}\end{array}$ \\
\hline \multicolumn{7}{|l|}{ Panel A - Male } \\
\hline Unemployment rate t-2 std. & $\begin{array}{l}-0.005 \\
(0.015)\end{array}$ & $\begin{array}{c}0.000 \\
(0.011)\end{array}$ & $\begin{array}{l}-0.052^{* * *} \\
(0.016)\end{array}$ & $\begin{array}{c}-0.002 \\
(0.007)\end{array}$ & $\begin{array}{l}-0.023 \\
(0.016)\end{array}$ & $\begin{array}{l}-0.032^{*} \\
(0.017)\end{array}$ \\
\hline Migrant Acceptance Index std. & $\begin{array}{c}0.017 \\
(0.012)\end{array}$ & $\begin{array}{l}-0.008 \\
(0.009)\end{array}$ & $\begin{array}{c}0.028 \\
(0.018)\end{array}$ & $\begin{array}{l}-0.005 \\
(0.004)\end{array}$ & $\begin{array}{c}0.020 \\
(0.017)\end{array}$ & $\begin{array}{l}-0.009 \\
(0.015)\end{array}$ \\
\hline Secondary education & $\begin{array}{l}-0.013 \\
(0.013)\end{array}$ & $\begin{array}{l}0.126^{* * *} \\
(0.011)\end{array}$ & $\begin{array}{c}0.034 \\
(0.021)\end{array}$ & $\begin{array}{c}0.003 \\
(0.007)\end{array}$ & $\begin{array}{l}0.048^{* * *} \\
(0.016)\end{array}$ & $\begin{array}{c}0.010 \\
(0.018)\end{array}$ \\
\hline Tertiary education & $\begin{array}{l}-0.043^{* *} \\
(0.020)\end{array}$ & $\begin{array}{l}0.259^{* * *} \\
(0.016)\end{array}$ & $\begin{array}{c}0.066^{* *} \\
(0.030)\end{array}$ & $\begin{array}{c}0.002 \\
(0.011)\end{array}$ & $\begin{array}{c}0.039^{*} \\
(0.022)\end{array}$ & $\begin{array}{c}0.025 \\
(0.031)\end{array}$ \\
\hline Participated in integration course & $\begin{array}{l}0.028^{* *} \\
(0.012)\end{array}$ & $\begin{array}{l}0.035^{* * *} \\
(0.010)\end{array}$ & $\begin{array}{l}0.073^{* * *} \\
(0.020)\end{array}$ & $\begin{array}{c}0.006 \\
(0.006)\end{array}$ & $\begin{array}{c}0.004 \\
(0.016)\end{array}$ & $\begin{array}{l}-0.025 \\
(0.016)\end{array}$ \\
\hline German skills before emigration & $\begin{array}{c}0.002 \\
(0.031)\end{array}$ & $\begin{array}{l}0.116^{* * *} \\
(0.029)\end{array}$ & $\begin{array}{c}0.090 \\
(0.055)\end{array}$ & $\begin{array}{l}0.030^{* * *} \\
(0.007)\end{array}$ & $\begin{array}{l}0.116^{* * *} \\
(0.039)\end{array}$ & $\begin{array}{c}0.025 \\
(0.050)\end{array}$ \\
\hline \multirow[t]{2}{*}{$\begin{array}{l}\text { Support from family \& friends } \\
\text { before emigration }\end{array}$} & $0.023^{*}$ & -0.005 & -0.030 & 0.000 & 0.013 & 0.023 \\
\hline & $(0.014)$ & $(0.011)$ & $(0.026)$ & $(0.007)$ & $(0.019)$ & $(0.021)$ \\
\hline Children in household & $\begin{array}{l}0.077^{* * *} \\
(0.017)\end{array}$ & $\begin{array}{c}0.027^{*} \\
(0.015)\end{array}$ & $\begin{array}{l}-0.072^{* *} \\
(0.029)\end{array}$ & $\begin{array}{c}0.004 \\
(0.010)\end{array}$ & $\begin{array}{l}-0.017 \\
(0.026)\end{array}$ & $\begin{array}{l}0.049^{* *} \\
(0.020)\end{array}$ \\
\hline Interview year $\mathrm{FE}$ & Yes & Yes & Yes & Yes & Yes & Yes \\
\hline Nuts-2 FE & Yes & Yes & Yes & Yes & Yes & Yes \\
\hline R-Squared & 0.090 & 0.375 & 0.203 & 0.070 & 0.138 & 0.082 \\
\hline $\mathrm{N}$ & 1527 & 1527 & 1527 & 1527 & 1527 & 1527 \\
\hline \multicolumn{7}{|l|}{ Panel B - Females } \\
\hline Unemployment rate t-2 std. & $\begin{array}{c}0.004 \\
(0.014)\end{array}$ & $\begin{array}{l}-0.013 \\
(0.015)\end{array}$ & $\begin{array}{l}-0.011 \\
(0.014)\end{array}$ & $\begin{array}{c}0.005 \\
(0.010)\end{array}$ & $\begin{array}{l}-0.039 \\
(0.024)\end{array}$ & $\begin{array}{c}0.029^{*} \\
(0.016)\end{array}$ \\
\hline Migrant Acceptance Index std. & $\begin{array}{c}0.014 \\
(0.020)\end{array}$ & $\begin{array}{l}-0.012 \\
(0.017)\end{array}$ & $\begin{array}{c}0.028^{* *} \\
(0.012)\end{array}$ & $\begin{array}{l}-0.027 \\
(0.021)\end{array}$ & $\begin{array}{c}0.033 \\
(0.021)\end{array}$ & $\begin{array}{c}0.013 \\
(0.020)\end{array}$ \\
\hline Secondary education & $\begin{array}{l}-0.013 \\
(0.015)\end{array}$ & $\begin{array}{l}0.111^{* * *} \\
(0.015)\end{array}$ & $\begin{array}{c}0.004 \\
(0.016)\end{array}$ & $\begin{array}{c}0.011 \\
(0.012)\end{array}$ & $\begin{array}{l}0.072^{* * *} \\
(0.020)\end{array}$ & $\begin{array}{l}-0.016 \\
(0.017)\end{array}$ \\
\hline Tertiary education & $\begin{array}{l}-0.027 \\
(0.024)\end{array}$ & $\begin{array}{l}0.206^{* * *} \\
(0.023)\end{array}$ & $\begin{array}{c}0.055^{* *} \\
(0.025)\end{array}$ & $\begin{array}{c}0.022 \\
(0.014)\end{array}$ & $\begin{array}{c}0.044 \\
(0.029)\end{array}$ & $\begin{array}{c}0.024 \\
(0.029)\end{array}$ \\
\hline Participated in integration course & $\begin{array}{l}0.059^{* * *} \\
(0.014)\end{array}$ & $\begin{array}{l}0.124^{* * * *} \\
(0.015)\end{array}$ & $\begin{array}{l}0.209^{* * * *} \\
(0.018)\end{array}$ & $\begin{array}{l}-0.010 \\
(0.011)\end{array}$ & $\begin{array}{c}0.040^{*} \\
(0.024)\end{array}$ & $\begin{array}{l}-0.002 \\
(0.019)\end{array}$ \\
\hline German skills before emigration & $\begin{array}{l}-0.050 \\
(0.035)\end{array}$ & $\begin{array}{c}0.078 \\
(0.048)\end{array}$ & $\begin{array}{c}0.004 \\
(0.055)\end{array}$ & $\begin{array}{l}-0.029 \\
(0.032)\end{array}$ & $\begin{array}{c}0.109^{*} \\
(0.056)\end{array}$ & $\begin{array}{r}0.132^{*} \\
(0.069)\end{array}$ \\
\hline \multirow[t]{2}{*}{$\begin{array}{l}\text { Support from family \& friends } \\
\text { before emigration }\end{array}$} & 0.024 & -0.023 & 0.021 & 0.011 & $-0.040^{*}$ & 0.009 \\
\hline & $(0.016)$ & $(0.019)$ & $(0.019)$ & $(0.009)$ & $(0.021)$ & $(0.020)$ \\
\hline Children in household & $\begin{array}{c}0.020 \\
(0.018)\end{array}$ & $\begin{array}{c}-0.017 \\
(0.019)\end{array}$ & $\begin{array}{l}-0.040^{*} \\
(0.021)\end{array}$ & $\begin{array}{l}-0.002 \\
(0.013)\end{array}$ & $\begin{array}{c}0.032 \\
(0.024)\end{array}$ & $\begin{array}{l}-0.004 \\
(0.027)\end{array}$ \\
\hline Interview year FE & Yes & Yes & Yes & Yes & Yes & Yes \\
\hline Nuts-2 FE & Yes & Yes & Yes & Yes & Yes & Yes \\
\hline R-Squared & 0.111 & 0.335 & 0.271 & 0.099 & 0.169 & 0.090 \\
\hline $\mathrm{N}$ & 950 & 950 & 950 & 950 & 950 & 950 \\
\hline
\end{tabular}

Note: * significant at 10\%; ${ }^{* *}$ significant at $5 \%$; ${ }^{* *}$ significant at $1 \%$. The standard errors are clustered on the county level and are displayed in parentheses. We pool observations from survey years 2016 to 2018 keeping only the most recent survey information. The sample is restricted to individuals with a minimum of two years of residence in Germany. Dimensions are set similar to Harder et al. (2018). Table A6 includes the full set of covariates, as described in Section 4. For illustrative purposes, some control variables are not shown. Reference categories are as follows: primary education, aged 18-24, two years of residence in Germany, and Syrian origin. Information on attitudes stems from the European Social Survey. We merge natives' mean values on attitudes towards immigrants based on refugees' year of arrival and first state of residence in Germany. Source: IAB-BAMF-SOEP Survey of Refugees, v35 (2016-2018) and European Social Survey (2014). 
Table A7: Robustness to omitted variable bias, Oster test

\begin{tabular}{lcccc}
\hline \hline & $\begin{array}{c}(1) \\
\text { In employment } \\
\text { or education }\end{array}$ & $\begin{array}{c}(2) \\
\text { Full- or part- } \\
\text { time employed }\end{array}$ & $\begin{array}{c}\text { Log net } \\
\text { wages }\end{array}$ & $\begin{array}{c}\text { Multi-dimensional } \\
\text { Integration Index }\end{array}$ \\
\cline { 2 - 5 } Unemployment rate & $-0.043^{* * *}$ & $-0.042^{* * *}$ & $-0.341^{* * *}$ & $-0.014^{* *}$ \\
& $(0.013)$ & $(0.012)$ & $(0.084)$ & $(0.007)$ \\
\hline Bounds on the treatment effect & $(-0.033,-0.043)$ & $(-0.033,-0.047)$ & $(-0.258,-0.341)$ & $(-0.009,-0.144)$ \\
Treatment excludes 0 & Yes & Yes & Yes & Yes \\
Delta (Rmax $\left.=1.3^{*} \mathrm{R}\right)$ & 8.015 & 25.162 & 10.129 & -17.435 \\
\hline \hline Migrant Acceptance Index & $0.050^{* * *}$ & $0.047^{* * *}$ & $0.178^{*}$ & $0.011^{*}$ \\
& $(0.016)$ & $(0.013)$ & $(0.092)$ & $(0.006)$ \\
\hline Bounds on the treatment effect & $(0.049,0.050)$ & $(0.026,0.024)$ & $(0.187,0.178)$ & $(0.009,0.011)$ \\
Treatment excludes 0 & Yes & Yes & Yes & Yes \\
Delta (Rmax $\left.=1.3^{*} \mathrm{R}\right)$ & -123.684 & 14.899 & 20.879 & -12.107 \\
\hline \hline
\end{tabular}

Note: ${ }^{*}$ significant at $10 \%$; ${ }^{*}$ significant at $5 \%$; ${ }^{* *}$ significant at $1 \%$. The standard levels are clustered on the state level and are displayed in parentheses. We pool observations from survey years 2016 to 2018 keeping only the most recent survey information. The sample is restricted to individuals with a minimum of two years of residence in Germany. Reference categories are as follows: primary education, aged 18-24, two years of residence in Germany, Syrian refugee. Information on attitudes stems from the European Social Survey. We merge natives' mean values on attitudes towards immigrants based on refugees' year of arrival and first state of residence in Germany. Source: IAB-BAMF-SOEP Survey of Refugees, v35 (2016-2018) and European Social Survey (2014). 
Table A8: Determinants of refugees' labor market and social outcomes, including NUTS- $2 *$ year fixed effects

\begin{tabular}{|c|c|c|c|c|}
\hline & $\begin{array}{c}(1) \\
\text { In employment } \\
\text { or education } \\
\mathrm{b} / \mathrm{se}\end{array}$ & $\begin{array}{c}(2) \\
\text { Full or } \\
\text { part-time } \\
\text { b/se }\end{array}$ & $\begin{array}{c}(3) \\
\text { Net monthly wages } \\
\mathrm{b} / \mathrm{se}\end{array}$ & $\begin{array}{c}(4) \\
\text { Multi-dimensional } \\
\text { Integration Index } \\
\mathrm{b} / \mathrm{se}\end{array}$ \\
\hline Unemployment rate t-2 std. & $\begin{array}{l}-0.048^{* * *} \\
(0.013)\end{array}$ & $\begin{array}{l}-0.049^{* * *} \\
(0.012)\end{array}$ & $\begin{array}{l}-0.367^{* * *} \\
(0.085)\end{array}$ & $\begin{array}{l}-0.014^{* *} \\
(0.007)\end{array}$ \\
\hline Migrant Acceptance Index std. & $\begin{array}{l}0.054^{* * *} \\
(0.016)\end{array}$ & $\begin{array}{l}0.044^{* * *} \\
(0.014)\end{array}$ & $\begin{array}{r}0.185^{*} \\
(0.094)\end{array}$ & $\begin{array}{l}0.014^{* *} \\
(0.006)\end{array}$ \\
\hline Female & $\begin{array}{l}-0.198^{* * *} \\
(0.015)\end{array}$ & $\begin{array}{l}-0.178^{* * *} \\
(0.014)\end{array}$ & $\begin{array}{l}-1.292^{* * *} \\
(0.095)\end{array}$ & $\begin{array}{l}-0.082^{* * *} \\
(0.006)\end{array}$ \\
\hline Secondary education & $\begin{array}{l}0.039^{* *} \\
(0.016)\end{array}$ & $\begin{array}{c}0.020 \\
(0.016)\end{array}$ & $\begin{array}{c}0.106 \\
(0.110)\end{array}$ & $\begin{array}{l}0.040^{* * *} \\
(0.007)\end{array}$ \\
\hline Tertiary education & $\begin{array}{l}0.065^{* * *} \\
(0.022)\end{array}$ & $\begin{array}{l}0.049^{* *} \\
(0.021)\end{array}$ & $\begin{array}{l}0.416^{* * *} \\
(0.156)\end{array}$ & $\begin{array}{l}0.067^{* * *} \\
(0.010)\end{array}$ \\
\hline Participated in integration course & $\begin{array}{l}-0.002 \\
(0.018)\end{array}$ & $\begin{array}{l}-0.009 \\
(0.017)\end{array}$ & $\begin{array}{l}-0.038 \\
(0.114)\end{array}$ & $\begin{array}{l}0.039^{* * *} \\
(0.006)\end{array}$ \\
\hline German skills before emigration & $\begin{array}{c}0.053 \\
(0.047)\end{array}$ & $\begin{array}{l}-0.011 \\
(0.042)\end{array}$ & $\begin{array}{c}0.139 \\
(0.367)\end{array}$ & $\begin{array}{l}0.071^{* * *} \\
(0.017)\end{array}$ \\
\hline Help finding a job & $\begin{array}{l}0.182^{* * *} \\
(0.024)\end{array}$ & $\begin{array}{l}0.139^{* * *} \\
(0.023)\end{array}$ & $\begin{array}{l}1.371^{* * *} \\
(0.181)\end{array}$ & \\
\hline $\begin{array}{l}\text { Support from family \& friends } \\
\text { before emigration }\end{array}$ & -0.029 & -0.020 & $-0.288^{* *}$ & 0.000 \\
\hline & $(0.018)$ & $(0.018)$ & $(0.129)$ & $(0.007)$ \\
\hline Children in household & $\begin{array}{l}-0.069^{* * *} \\
(0.020)\end{array}$ & $\begin{array}{l}-0.074^{* * *} \\
(0.019)\end{array}$ & $\begin{array}{l}-0.572^{* * * *} \\
(0.140)\end{array}$ & $\begin{array}{c}0.004 \\
(0.009)\end{array}$ \\
\hline Married/ In partnership & $\begin{array}{l}-0.046^{* *} \\
(0.022)\end{array}$ & $\begin{array}{c}0.017 \\
(0.023)\end{array}$ & $\begin{array}{c}0.030 \\
(0.154)\end{array}$ & $\begin{array}{l}-0.025^{* * *} \\
(0.008)\end{array}$ \\
\hline Satisfactory health status & $\begin{array}{l}0.062^{* * *} \\
(0.021)\end{array}$ & $\begin{array}{l}0.048^{* * *} \\
(0.017)\end{array}$ & $\begin{array}{l}0.266^{* *} \\
(0.134)\end{array}$ & $\begin{array}{l}0.042^{\text {*** }} \\
(0.010)\end{array}$ \\
\hline Nuts- $2 *$ Year FE & Yes & Yes & Yes & Yes \\
\hline R-Squared & 0.248 & 0.226 & 0.246 & 0.274 \\
\hline $\mathrm{N}$ & 3170 & 2434 & 3013 & 2477 \\
\hline
\end{tabular}

Note: ${ }^{*}$ significant at $10 \% ;{ }^{* *}$ significant at $5 \% ;{ }^{* * *}$ significant at $1 \%$. The standard errors are clustered on the county level and are displayed in parentheses. We pool observations from survey years 2016 to 2018 keeping only the most recent survey information. The sample is restricted to individuals with a minimum of two years of residence in Germany. Outcome variable "In employment or education" is one for refugees who report being in employment or education. Outcome variable "Full- or part-time employed" is one for refugees who report being in full- or part-time employment. Outcome "Net monthly wages" are net monthly wages, in inverse hyperbolic sine transformation. Table A8 includes the full set of covariates, as described in Section 4. For illustrative purposes, some control variables are not shown. Reference categories are as follows: primary education, aged 18-24 (aged 25-29 for full- or part-time employment), two years of residence in Germany, and Syrian origin. Information on attitudes stems from the European Social Survey. We merge natives' mean values on attitudes towards immigrants based on refugees' year of arrival and first state of residence in Germany. Source: IAB-BAMF-SOEP Survey of Refugees, v35 (2016-2018) and European Social Survey (2014). 
Table A9: Effect of unemployment and attitudes towards immigrants on the dimensions of the Multi-dimensional Integration Index, including NUTS-2*year fixed effects

\begin{tabular}{|c|c|c|c|c|c|c|}
\hline & $\begin{array}{c}(1) \\
\text { Psychological } \\
\text { b/se }\end{array}$ & $\begin{array}{c}(2) \\
\text { Linguistic } \\
\text { b/se }\end{array}$ & $\begin{array}{c}(3) \\
\text { Economic } \\
\text { b/se }\end{array}$ & $\begin{array}{c}(4) \\
\text { Political } \\
\text { b/se }\end{array}$ & $\begin{array}{c}(5) \\
\text { Social } \\
\text { b/se }\end{array}$ & $\begin{array}{c}(6) \\
\text { Navigational } \\
\mathrm{b} / \mathrm{se}\end{array}$ \\
\hline Unemployment rate t-2 std. & $\begin{array}{c}0.001 \\
(0.012)\end{array}$ & $\begin{array}{l}-0.005 \\
(0.009)\end{array}$ & $\begin{array}{l}-0.038^{* * *} \\
(0.012)\end{array}$ & $\begin{array}{c}0.005 \\
(0.006)\end{array}$ & $\begin{array}{l}-0.026^{*} \\
(0.015)\end{array}$ & $\begin{array}{l}-0.009 \\
(0.012)\end{array}$ \\
\hline Migrant Acceptance Index std. & $\begin{array}{c}0.018 \\
(0.012)\end{array}$ & $\begin{array}{l}-0.004 \\
(0.008)\end{array}$ & $\begin{array}{l}0.037^{* * *} \\
(0.013)\end{array}$ & $\begin{array}{l}-0.013 \\
(0.008)\end{array}$ & $\begin{array}{l}0.029^{* *} \\
(0.013)\end{array}$ & $\begin{array}{c}0.001 \\
(0.012)\end{array}$ \\
\hline Female & $\begin{array}{c}0.005 \\
(0.008)\end{array}$ & $\begin{array}{l}-0.074^{* * *} \\
(0.010)\end{array}$ & $\begin{array}{l}-0.215^{* * *} \\
(0.013)\end{array}$ & $\begin{array}{l}-0.008 \\
(0.006)\end{array}$ & $\begin{array}{l}-0.093^{* * *} \\
(0.012)\end{array}$ & $\begin{array}{l}-0.044^{* * *} \\
(0.011)\end{array}$ \\
\hline Secondary education & $\begin{array}{l}-0.009 \\
(0.010)\end{array}$ & $\begin{array}{l}0.124^{* * *} \\
(0.009)\end{array}$ & $\begin{array}{c}0.022 \\
(0.014)\end{array}$ & $\begin{array}{c}0.007 \\
(0.006)\end{array}$ & $\begin{array}{l}0.057^{* * *} \\
(0.013)\end{array}$ & $\begin{array}{c}0.003 \\
(0.014)\end{array}$ \\
\hline Tertiary education & $\begin{array}{l}-0.032^{*} \\
(0.017)\end{array}$ & $\begin{array}{l}0.240^{* * *} \\
(0.014)\end{array}$ & $\begin{array}{l}0.063^{* * *} \\
(0.020)\end{array}$ & $\begin{array}{r}0.014^{*} \\
(0.008)\end{array}$ & $\begin{array}{l}0.045^{* *} \\
(0.019)\end{array}$ & $\begin{array}{c}0.030 \\
(0.023)\end{array}$ \\
\hline Participated in integration course & $\begin{array}{l}0.037^{* * *} \\
(0.010)\end{array}$ & $\begin{array}{l}0.071^{* * *} \\
(0.009)\end{array}$ & $\begin{array}{l}0.117^{* * *} \\
(0.015)\end{array}$ & $\begin{array}{l}-0.002 \\
(0.006)\end{array}$ & $\begin{array}{c}0.008 \\
(0.013)\end{array}$ & $\begin{array}{l}-0.016 \\
(0.012)\end{array}$ \\
\hline German skills before emigration & $\begin{array}{l}-0.007 \\
(0.025)\end{array}$ & $\begin{array}{l}0.104^{* * *} \\
(0.025)\end{array}$ & $\begin{array}{c}0.081^{*} \\
(0.043)\end{array}$ & $\begin{array}{c}0.015 \\
(0.011)\end{array}$ & $\begin{array}{l}0.108^{* * *} \\
(0.031)\end{array}$ & $\begin{array}{c}0.063 \\
(0.041)\end{array}$ \\
\hline $\begin{array}{c}\text { Support from family \& friends } \\
\text { before emigration }\end{array}$ & $0.021^{* *}$ & -0.012 & -0.012 & 0.002 & -0.015 & 0.020 \\
\hline & $(0.011)$ & $(0.010)$ & $(0.016)$ & $(0.006)$ & $(0.016)$ & $(0.014)$ \\
\hline Children in household & $\begin{array}{l}0.053^{* * *} \\
(0.013)\end{array}$ & $\begin{array}{c}0.004 \\
(0.012)\end{array}$ & $\begin{array}{l}-0.066^{* * *} \\
(0.019)\end{array}$ & $\begin{array}{c}0.003 \\
(0.008)\end{array}$ & $\begin{array}{c}0.002 \\
(0.018)\end{array}$ & $\begin{array}{c}0.027 \\
(0.017)\end{array}$ \\
\hline Married/ In partnership & $\begin{array}{l}-0.003 \\
(0.013)\end{array}$ & $\begin{array}{l}-0.044^{* * *} \\
(0.012)\end{array}$ & $\begin{array}{l}-0.016 \\
(0.019)\end{array}$ & $\begin{array}{c}0.001 \\
(0.008)\end{array}$ & $\begin{array}{l}-0.045^{* *} \\
(0.018)\end{array}$ & $\begin{array}{l}-0.021 \\
(0.017)\end{array}$ \\
\hline Satisfactory health status & $\begin{array}{l}0.057^{* * *} \\
(0.015)\end{array}$ & $\begin{array}{l}0.051^{* * *} \\
(0.014)\end{array}$ & $\begin{array}{l}0.050^{* *} \\
(0.019)\end{array}$ & $\begin{array}{c}0.015 \\
(0.012)\end{array}$ & $\begin{array}{l}0.060^{* * *} \\
(0.021)\end{array}$ & $\begin{array}{l}-0.018 \\
(0.018)\end{array}$ \\
\hline Nuts- $2 *$ Year FE & Yes & Yes & Yes & Yes & Yes & Yes \\
\hline R-Squared & 0.106 & 0.375 & 0.282 & 0.095 & 0.196 & 0.100 \\
\hline $\mathrm{N}$ & 2477 & 2477 & 2477 & 2477 & 2477 & 2477 \\
\hline
\end{tabular}

Note: ${ }^{*}$ significant at $10 \% ;{ }^{* *}$ significant at $5 \% ;{ }^{* *}$ significant at $1 \%$. The standard errors are clustered on the county level and are displayed in parentheses. We pool observations from survey years 2016 to 2018 keeping only the most recent survey information. The sample is restricted to individuals with a minimum of two years of residence in Germany. Dimensions are set similar to Harder et al. (2018). Table A9 includes the full set of covariates, as described in Section 4. For illustrative purposes, some control variables are not shown. Reference categories are as follows: primary education, aged 18-24, two years of residence in Germany, and Syrian origin. Information on attitudes stems from the European Social Survey. We merge natives' mean values on attitudes towards immigrants based on refugees' year of arrival and first state of residence in Germany. Source: IAB-BAMF-SOEP Survey of Refugees, v35 (2016-2018) and European Social Survey (2014). 
Table A10: Multiple hypothesis testing - Main results

\begin{tabular}{|c|c|c|c|c|}
\hline & $\begin{array}{c}(1) \\
\text { In employment } \\
\text { or education }\end{array}$ & $\begin{array}{c}\text { (2) } \\
\text { Full- or part- } \\
\text { time employed }\end{array}$ & $\begin{array}{l}(3) \\
\text { Net monthly } \\
\text { wages }\end{array}$ & $\begin{array}{l}\text { (4) } \\
\text { Multi-dimensional } \\
\text { Integration Index }\end{array}$ \\
\hline Unemployment rate & $\begin{array}{l}-0.048^{* * *} \\
(0.013)\end{array}$ & $\begin{array}{l}-0.049^{* * *} \\
(0.012)\end{array}$ & $\begin{array}{l}-0.367^{* * *} \\
(0.85)\end{array}$ & $\begin{array}{l}-0.014^{* *} \\
(0.007)\end{array}$ \\
\hline $\mathrm{N}$ & 3,170 & 2,434 & 3,013 & 2,477 \\
\hline $\begin{array}{l}\text { Randomization-t p-values } \\
\text { Randomization-t p-values }\end{array}$ & $0.004^{* * *}$ & $0.004^{* * *}$ & $0.002^{* * *}$ & $0.052^{*}$ \\
\hline $\begin{array}{l}\text { Westfall-Young multiple testing } \\
\text { of treatment significance }\end{array}$ & & & & $0.006^{* *}$ \\
\hline Migrant Acceptance Index & $\begin{array}{l}0.054^{* * *} \\
(0.016)\end{array}$ & $\begin{array}{l}0.044^{* * *} \\
(0.014)\end{array}$ & $\begin{array}{c}0.185^{*} \\
(0.094)\end{array}$ & $\begin{array}{l}0.014^{* *} \\
(0.006)\end{array}$ \\
\hline $\mathrm{N}$ & 3,170 & 2,434 & 3,013 & 2,477 \\
\hline $\begin{array}{l}\text { Randomization-t p-values } \\
\text { Randomization-t p-values }\end{array}$ & $0.004^{* * *}$ & $0.004^{* * *}$ & $0.018^{* *}$ & $0.094^{*}$ \\
\hline $\begin{array}{l}\text { Westfall-Young multiple testing } \\
\text { of treatment significance }\end{array}$ & & & & $0.012^{* *}$ \\
\hline
\end{tabular}

Note: $*$ significant at $10 \%$;* significant at $5 \%$; ** significant at $1 \%$. The standard levels are clustered on the county and year of interview level and are displayed in parenthesis. We pool observations from survey years 2016 to 2018 keeping only the most recent survey information. The sample is restricted to individuals with a minimum of two years of residence in Germany. Reference categories are as follows: primary education, aged 18-24, two years of residence in Germany, Syrian refugee. Information on attitudes stems from the European Social Survey. We merge natives' mean values on attitudes towards immigrants based on refugees' year of arrival and first state of residence in Germany. Source: IAB-BAMF-SOEP Survey of Refugees, v35 (2016-2018) and European Social Survey (2014). 
Table A11: Determinants of refugees' labor market and social outcomes

\begin{tabular}{|c|c|c|c|c|}
\hline & $\begin{array}{c}(1) \\
\text { In employment } \\
\text { or education } \\
\mathrm{b} / \mathrm{se}\end{array}$ & $\begin{array}{c}(2) \\
\text { Full or } \\
\text { part-time } \\
\text { b/se }\end{array}$ & $\begin{array}{c}(3) \\
\text { Net monthly wages } \\
\mathrm{b} / \mathrm{se}\end{array}$ & $\begin{array}{c}(4) \\
\text { Multi-dimensional } \\
\text { Integration Index } \\
\mathrm{b} / \mathrm{se}\end{array}$ \\
\hline Unemployment rate t-2 std. & $\begin{array}{l}-0.044^{* * *} \\
(0.013)\end{array}$ & $\begin{array}{l}-0.042^{* * *} \\
(0.012)\end{array}$ & $\begin{array}{l}-0.339^{* * *} \\
(0.085)\end{array}$ & $\begin{array}{l}-0.014^{* *} \\
(0.007)\end{array}$ \\
\hline Diversity Index std. & $\begin{array}{l}0.213^{* * *} \\
(0.072)\end{array}$ & $\begin{array}{l}0.178^{* *} \\
(0.069)\end{array}$ & $\begin{array}{l}1.021^{* *} \\
(0.498)\end{array}$ & $\begin{array}{c}0.059^{*} \\
(0.034)\end{array}$ \\
\hline Female & $\begin{array}{l}-0.197^{* * *} \\
(0.015)\end{array}$ & $\begin{array}{l}-0.174^{* * *} \\
(0.013)\end{array}$ & $\begin{array}{l}-1.289^{* * *} \\
(0.093)\end{array}$ & $\begin{array}{l}-0.081^{* * *} \\
(0.005)\end{array}$ \\
\hline Secondary education & $\begin{array}{l}0.040^{* * *} \\
(0.015)\end{array}$ & $\begin{array}{c}0.021 \\
(0.015)\end{array}$ & $\begin{array}{c}0.118 \\
(0.107)\end{array}$ & $\begin{array}{l}0.040^{* * *} \\
(0.007)\end{array}$ \\
\hline Tertiary education & $\begin{array}{l}0.060^{* * *} \\
(0.021)\end{array}$ & $\begin{array}{l}0.048^{* *} \\
(0.021)\end{array}$ & $\begin{array}{l}0.390^{* *} \\
(0.152)\end{array}$ & $\begin{array}{l}0.065^{* * *} \\
(0.010)\end{array}$ \\
\hline Participated in integration course & $\begin{array}{c}0.002 \\
(0.018)\end{array}$ & $\begin{array}{l}-0.007 \\
(0.016)\end{array}$ & $\begin{array}{l}-0.004 \\
(0.112)\end{array}$ & $\begin{array}{l}0.042^{* * *} \\
(0.006)\end{array}$ \\
\hline German skills before emigration & $\begin{array}{c}0.052 \\
(0.048)\end{array}$ & $\begin{array}{l}-0.008 \\
(0.041)\end{array}$ & $\begin{array}{c}0.209 \\
(0.370)\end{array}$ & $\begin{array}{l}0.072^{* * *} \\
(0.017)\end{array}$ \\
\hline Help finding a job & $\begin{array}{l}0.178^{* * *} \\
(0.023)\end{array}$ & $\begin{array}{l}0.133^{* * *} \\
(0.023)\end{array}$ & $\begin{array}{l}1.354^{* * *} \\
(0.180)\end{array}$ & \\
\hline $\begin{array}{l}\text { Support from family \& friends } \\
\text { before emigration }\end{array}$ & -0.027 & -0.017 & $-0.266^{* *}$ & 0.002 \\
\hline Children in household & $\begin{array}{l}(0.018) \\
-0.074^{* * *} \\
(0.020)\end{array}$ & $\begin{array}{l}(0.018) \\
-0.074^{* * *} \\
(0.019)\end{array}$ & $\begin{array}{l}(0.127) \\
-0.603^{* * *} \\
(0.139)\end{array}$ & $\begin{array}{c}(0.007) \\
0.003 \\
(0.009)\end{array}$ \\
\hline Married/ In partnership & $\begin{array}{l}-0.043^{* *} \\
(0.021)\end{array}$ & $\begin{array}{c}0.018 \\
(0.023)\end{array}$ & $\begin{array}{c}0.052 \\
(0.151)\end{array}$ & $\begin{array}{l}-0.024^{* * *} \\
(0.008)\end{array}$ \\
\hline Satisfactory health status & $\begin{array}{l}0.063^{* * *} \\
(0.020)\end{array}$ & $\begin{array}{l}0.055^{* * *} \\
(0.017)\end{array}$ & $\begin{array}{l}0.287^{* *} \\
(0.128)\end{array}$ & $\begin{array}{l}0.045^{* * *} \\
(0.010)\end{array}$ \\
\hline Interview year FE & Yes & Yes & Yes & Yes \\
\hline Nuts-2 FE & Yes & Yes & Yes & Yes \\
\hline R-Squared & 0.228 & 0.203 & 0.228 & 0.253 \\
\hline $\mathrm{N}$ & 3170 & 2434 & 3013 & 2477 \\
\hline
\end{tabular}

Note: ${ }^{*}$ significant at $10 \% ;{ }^{* *}$ significant at $5 \% ;{ }^{* * *}$ significant at $1 \%$. The standard levels are clustered on the county level and are displayed in parentheses. We pool observations from survey years 2016 to 2018 keeping only the most recent survey information. The sample is restricted to individuals with a minimum of two years of residence in Germany. Outcome variable "In employment or education" is one for refugees who report being in employment or education. Outcome variable "Full- or part-time employed" is one for refugees who report being in full- or part-time employment. Outcome "Net monthly wages" are net monthly wages, in inverse hyperbolic sine transformation. Table A11 includes the full set of covariates, as described in Section 4. For illustrative purposes, some control variables are not shown. Reference categories are as follows: primary education, aged 18-24 (aged 25-29 for full- or part-time employment), two years of residence in Germany, and Syrian origin. Information on the diversity index stems from the Gallup World Polls. We merge natives' mean values on attitudes towards immigrants based on refugees' year of arrival and first state of residence in Germany. Source: IAB-BAMF-SOEP Survey of Refugees, v35 (2016-2018) and Gallup World Polls (2014). 
Table A12: Logistic regression: Determinants of refugees' labor market outcomes

\begin{tabular}{|c|c|c|}
\hline & $\begin{array}{c}(1) \\
\text { In employment } \\
\text { or education } \\
\text { b/se }\end{array}$ & $\begin{array}{c}(2) \\
\text { Full or } \\
\text { part-time } \\
\text { b/se }\end{array}$ \\
\hline Unemployment rate t-2 std. & $\begin{array}{l}-0.292^{* * *} \\
(0.083)\end{array}$ & $\begin{array}{l}-0.431^{* * *} \\
(0.115)\end{array}$ \\
\hline Migrant Acceptance Index std. & $\begin{array}{l}0.330^{* * *} \\
(0.109)\end{array}$ & $\begin{array}{l}0.436^{* * *} \\
(0.134)\end{array}$ \\
\hline Female & $\begin{array}{l}-1.400^{* * *} \\
(0.111)\end{array}$ & $\begin{array}{l}-2.041^{* * *} \\
(0.184)\end{array}$ \\
\hline Secondary education & $\begin{array}{l}0.264^{* * *} \\
(0.097)\end{array}$ & $\begin{array}{c}0.185 \\
(0.139)\end{array}$ \\
\hline Tertiary education & $\begin{array}{l}0.389^{* * *} \\
(0.130)\end{array}$ & $\begin{array}{l}0.419^{* *} \\
(0.167)\end{array}$ \\
\hline Participated in integration course & $\begin{array}{c}0.072 \\
(0.113)\end{array}$ & $\begin{array}{c}0.086 \\
(0.146)\end{array}$ \\
\hline German skills before emigration & $\begin{array}{c}0.350 \\
(0.253)\end{array}$ & $\begin{array}{l}0.028 \\
(0.304)\end{array}$ \\
\hline Help finding a job & $\begin{array}{l}0.945^{* * *} \\
(0.121)\end{array}$ & $\begin{array}{l}0.853^{* * *} \\
(0.144)\end{array}$ \\
\hline $\begin{array}{l}\text { Support from family \& friends } \\
\text { before emigration }\end{array}$ & -0.183 & -0.121 \\
\hline Children in household & $\begin{array}{l}(0.123) \\
-0.477^{* * *} \\
(0.122)\end{array}$ & $\begin{array}{l}(0.184) \\
-0.596^{* * *} \\
(0.159)\end{array}$ \\
\hline Married/ In partnership & $\begin{array}{l}-0.217 \\
(0.135)\end{array}$ & $\begin{array}{c}0.204 \\
(0.211)\end{array}$ \\
\hline Satisfactory health status & $\begin{array}{l}0.664^{* * *} \\
(0.211)\end{array}$ & $\begin{array}{l}0.977^{* * *} \\
(0.290)\end{array}$ \\
\hline $\begin{array}{l}\text { Interview year FE } \\
\text { Nuts- } 2 \text { FE }\end{array}$ & $\begin{array}{l}\text { Yes } \\
\text { Yes }\end{array}$ & $\begin{array}{l}\text { Yes } \\
\text { Yes }\end{array}$ \\
\hline $\begin{array}{l}\text { Pseudo R-Squared } \\
\mathrm{N}\end{array}$ & $\begin{array}{l}0.218 \\
3170\end{array}$ & $\begin{array}{l}0.255 \\
2434\end{array}$ \\
\hline
\end{tabular}

Note: ${ }^{*}$ significant at $10 \% ;{ }^{* *}$ significant at $5 \% ;{ }^{* * *}$ significant at $1 \%$. The standard levels are clustered on the county level and are displayed in parentheses. We pool observations from survey years 2016 to 2018 keeping only the most recent survey information. The sample is restricted to individuals with a minimum of two years of residence in Germany. Outcome variable "In employment or education" is one for refugees who report being in employment or education. Outcome variable "Fullor part-time employed" is one for refugees who report being in full- or part-time employment. Estimates are reported as odd ratios. Table A12 includes the full set of covariates, as described in Section 4. For illustrative purposes, some control variables are not shown. Reference categories are as follows: primary education, aged 18-24 (aged 25-29 for full- or part-time employment), two years of residence in Germany, and Syrian origin. Information on attitudes stems from the European Social Survey. We merge natives' mean values on attitudes towards immigrants based on refugees' year of arrival and first state of residence in Germany. Source: IAB-BAMF-SOEP Survey of Refugees, v35 (2016-2018) and European Social Survey (2014). 
Table A13: Determinants of refugees' labor market and social outcomes, adults aged 18-64

\begin{tabular}{|c|c|c|c|c|}
\hline & $\begin{array}{c}(1) \\
\text { In employment } \\
\text { or education } \\
\mathrm{b} / \mathrm{se}\end{array}$ & $\begin{array}{c}(2) \\
\text { Full or } \\
\text { part-time } \\
\text { b/se }\end{array}$ & $\begin{array}{c}(3) \\
\text { Net monthly wages } \\
\mathrm{b} / \mathrm{se}\end{array}$ & $\begin{array}{c}(4) \\
\text { Multi-dimensional } \\
\text { Integration Index } \\
\mathrm{b} / \mathrm{se}\end{array}$ \\
\hline \multirow[t]{2}{*}{ Unemployment rate t-2 std. } & $-0.039^{* * *}$ & $-0.037^{* * *}$ & $-0.302^{* * *}$ & $-0.015^{* *}$ \\
\hline & $(0.012)$ & $(0.011)$ & $(0.081)$ & $(0.006)$ \\
\hline \multirow[t]{2}{*}{ Migrant Acceptance Index std. } & $0.041^{* *}$ & $0.035^{* *}$ & $0.160^{*}$ & $0.011^{*}$ \\
\hline & $(0.017)$ & $(0.014)$ & $(0.089)$ & $(0.006)$ \\
\hline \multirow[t]{2}{*}{ Female } & $-0.182^{* * *}$ & $-0.159 * * *$ & $-1.196^{* * *}$ & $-0.076^{* * *}$ \\
\hline & $(0.013)$ & $(0.012)$ & $(0.084)$ & $(0.005)$ \\
\hline \multirow[t]{2}{*}{ Secondary education } & $0.040^{* * *}$ & 0.022 & 0.111 & $0.039^{* * *}$ \\
\hline & $(0.014)$ & $(0.014)$ & $(0.097)$ & $(0.006)$ \\
\hline \multirow[t]{2}{*}{ Tertiary education } & $0.060^{* * *}$ & $0.044^{* *}$ & $0.355^{* * *}$ & $0.065^{* * *}$ \\
\hline & $(0.018)$ & $(0.018)$ & $(0.130)$ & $(0.009)$ \\
\hline \multirow[t]{2}{*}{ Participated in integration course } & 0.000 & -0.011 & -0.048 & $0.040^{* * *}$ \\
\hline & $(0.017)$ & $(0.015)$ & $(0.104)$ & $(0.005)$ \\
\hline \multirow[t]{2}{*}{ German skills before emigration } & 0.014 & -0.032 & -0.011 & $0.068^{* * *}$ \\
\hline & $(0.043)$ & $(0.036)$ & $(0.332)$ & $(0.015)$ \\
\hline \multirow[t]{2}{*}{ Help finding a job } & $0.176^{* * *}$ & $0.131^{* * *}$ & $1.328^{* * *}$ & \\
\hline & $(0.023)$ & $(0.022)$ & $(0.175)$ & \\
\hline \multirow[t]{2}{*}{$\begin{array}{l}\text { Support from family \& friends } \\
\text { before emigration }\end{array}$} & $-0.028^{*}$ & -0.021 & $-0.265^{* *}$ & 0.003 \\
\hline & $(0.016)$ & $(0.016)$ & $(0.118)$ & $(0.006)$ \\
\hline \multirow[t]{2}{*}{ Children in household } & $-0.073^{* * *}$ & $-0.068^{* * *}$ & $-0.574^{* * *}$ & 0.002 \\
\hline & $(0.018)$ & $(0.017)$ & $(0.124)$ & $(0.008)$ \\
\hline \multirow[t]{2}{*}{ Married/ In partnership } & $-0.050 * *$ & 0.003 & -0.024 & $-0.025^{* * *}$ \\
\hline & $(0.019)$ & $(0.020)$ & $(0.136)$ & $(0.007)$ \\
\hline \multirow[t]{2}{*}{ Satisfactory health status } & $0.056^{* * *}$ & $0.048^{* * *}$ & $0.244^{* *}$ & $0.045^{* * *}$ \\
\hline & $(0.018)$ & $(0.015)$ & $(0.109)$ & $(0.008)$ \\
\hline Interview year $\mathrm{FE}$ & Yes & Yes & Yes & Yes \\
\hline Nuts-2 FE & Yes & Yes & Yes & Yes \\
\hline R-Squared & 0.230 & 0.199 & 0.227 & 0.261 \\
\hline $\mathrm{N}$ & 3484 & 2748 & 3315 & 2727 \\
\hline
\end{tabular}

Note: ${ }^{*}$ significant at $10 \% ;{ }^{* *}$ significant at $5 \% ;{ }^{* * *}$ significant at $1 \%$. The standard levels are clustered on the county level and are displayed in parentheses. We pool observations from survey years 2016 to 2018 keeping only the most recent survey information. The sample is restricted to individuals with a minimum of two years of residence in Germany. Outcome variable "In employment or education" is one for refugees who report being in employment or education. Outcome variable "Full- or part-time employed" is one for refugees who report being in full- or part-time employment. Outcome "Net monthly wages" are net monthly wages, in inverse hyperbolic sine transformation. Table A13 includes the full set of covariates, as described in Section 4. For illustrative purposes, some control variables are not shown. Reference categories are as follows: primary education, aged 18-24 (aged 25-29 for full- or part-time employment), two years of residence in Germany, and Syrian origin. Information on attitudes stems from the European Social Survey. We merge natives' mean values on attitudes towards immigrants based on refugees' year of arrival and first state of residence in Germany. Source: IAB-BAMF-SOEP Survey of Refugees, v35 (2016-2018) and European Social Survey (2014). 
Table A14: Determinants of refugees' labor market and social outcomes, robustness to excluding counties with very few refugees

\begin{tabular}{|c|c|c|c|c|}
\hline & $\begin{array}{c}(1) \\
\text { In employment } \\
\text { or education } \\
\text { b/se }\end{array}$ & $\begin{array}{c}(2) \\
\text { Full or } \\
\text { part-time } \\
\text { b/se }\end{array}$ & $\begin{array}{c}(3) \\
\text { Net monthly wages } \\
\mathrm{b} / \mathrm{se}\end{array}$ & $\begin{array}{c}(4) \\
\text { Multi-dimensional } \\
\text { Integration Index } \\
\mathrm{b} / \mathrm{se}\end{array}$ \\
\hline Unemployment rate t- 2 std. & $\begin{array}{l}-0.046^{* * *} \\
(0.013)\end{array}$ & $\begin{array}{l}-0.053^{* * *} \\
(0.014)\end{array}$ & $\begin{array}{l}-0.415^{* * *} \\
(0.096)\end{array}$ & $\begin{array}{l}-0.025^{* * *} \\
(0.008)\end{array}$ \\
\hline Migrant Acceptance Index std. & $\begin{array}{l}0.051^{* * *} \\
(0.018)\end{array}$ & $\begin{array}{l}0.051^{* * *} \\
(0.015)\end{array}$ & $\begin{array}{c}0.181^{*} \\
(0.094)\end{array}$ & $\begin{array}{c}0.009 \\
(0.007)\end{array}$ \\
\hline Female & $\begin{array}{l}-0.197^{* * *} \\
(0.015)\end{array}$ & $\begin{array}{l}-0.174^{* * *} \\
(0.014)\end{array}$ & $\begin{array}{l}-1.261^{* * *} \\
(0.097)\end{array}$ & $\begin{array}{l}-0.080^{* * *} \\
(0.006)\end{array}$ \\
\hline Secondary education & $\begin{array}{l}0.032^{* *} \\
(0.016)\end{array}$ & $\begin{array}{c}0.018 \\
(0.016)\end{array}$ & $\begin{array}{c}0.132 \\
(0.112)\end{array}$ & $\begin{array}{l}0.039^{* * *} \\
(0.007)\end{array}$ \\
\hline Tertiary education & $\begin{array}{l}0.047^{* *} \\
(0.021)\end{array}$ & $\begin{array}{c}0.043^{*} \\
(0.022)\end{array}$ & $\begin{array}{l}0.368^{* *} \\
(0.161)\end{array}$ & $\begin{array}{l}0.063^{* * *} \\
(0.011)\end{array}$ \\
\hline Participated in integration course & $\begin{array}{l}-0.006 \\
(0.019)\end{array}$ & $\begin{array}{l}-0.011 \\
(0.017)\end{array}$ & $\begin{array}{l}-0.061 \\
(0.118)\end{array}$ & $\begin{array}{l}0.043^{* * *} \\
(0.006)\end{array}$ \\
\hline German skills before emigration & $\begin{array}{c}0.046 \\
(0.051)\end{array}$ & $\begin{array}{l}-0.015 \\
(0.043)\end{array}$ & $\begin{array}{c}0.108 \\
(0.392)\end{array}$ & $\begin{array}{l}0.062^{* * *} \\
(0.017)\end{array}$ \\
\hline Help finding a job & $\begin{array}{l}0.187^{* * *} \\
(0.025)\end{array}$ & $\begin{array}{l}0.132^{* * *} \\
(0.023)\end{array}$ & $\begin{array}{l}1.341^{* * *} \\
(0.192)\end{array}$ & \\
\hline $\begin{array}{c}\text { Support from family \& friends } \\
\text { before emigration }\end{array}$ & -0.027 & -0.017 & $-0.270^{* *}$ & 0.004 \\
\hline & $(0.019)$ & $(0.019)$ & $(0.135)$ & $(0.007)$ \\
\hline Children in household & $\begin{array}{l}-0.073^{* * *} \\
(0.020)\end{array}$ & $\begin{array}{l}-0.075^{* * *} \\
(0.020)\end{array}$ & $\begin{array}{l}-0.587^{* * *} \\
(0.144)\end{array}$ & $\begin{array}{c}0.002 \\
(0.010)\end{array}$ \\
\hline Married/ In partnership & $\begin{array}{l}-0.042^{*} \\
(0.023)\end{array}$ & $\begin{array}{l}0.015 \\
(0.025)\end{array}$ & $\begin{array}{c}0.040 \\
(0.163)\end{array}$ & $\begin{array}{l}-0.023^{* * *} \\
(0.009)\end{array}$ \\
\hline Satisfactory health status & $\begin{array}{l}0.050^{* *} \\
(0.021)\end{array}$ & $\begin{array}{l}0.041^{* *} \\
(0.017)\end{array}$ & $\begin{array}{c}0.180 \\
(0.133)\end{array}$ & $\begin{array}{l}0.039^{* * *} \\
(0.010)\end{array}$ \\
\hline Interview year FE & Yes & Yes & Yes & Yes \\
\hline Nuts-2 FE & Yes & Yes & Yes & Yes \\
\hline R-Squared & 0.229 & 0.209 & 0.232 & 0.250 \\
\hline $\mathrm{N}$ & 2808 & 2140 & 2670 & 2191 \\
\hline
\end{tabular}

Note: ${ }^{*}$ significant at 10\%; ${ }^{* *}$ significant at 5\%; ${ }^{* * *}$ significant at 1\%. The standard levels are clustered on the county level and are displayed in parentheses. We pool observations from survey years 2016 to 2018 keeping only the most recent survey information. The sample is restricted to individuals with a minimum of two years of residence in Germany. Outcome variable "In employment or education" is one for refugees who report being in employment or education. Outcome variable "Full- or part-time employed" is one for refugees who report being in full- or part-time employment. Outcome "Net monthly wages" are net monthly wages, in inverse hyperbolic sine transformation. Table A14 includes the full set of covariates, as described in Section 4. For illustrative purposes, some control variables are not shown. Reference categories are as follows: primary education, aged 18-24 (aged 25-29 for full- or part-time employment), two years of residence in Germany, and Syrian origin. Information on attitudes stems from the European Social Survey. We merge natives' mean values on attitudes towards immigrants based on refugees' year of arrival and first state of residence in Germany. Source: IAB-BAMF-SOEP Survey of Refugees, v35 (2016-2018) and European Social Survey (2014). 
Table A15: Determinants of refugees' labor market and social outcomes, clustering standard errors on the gender, education, and state level

\begin{tabular}{|c|c|c|c|c|}
\hline & $\begin{array}{c}\text { (1) } \\
\text { In employment } \\
\text { or education } \\
\text { b/se }\end{array}$ & $\begin{array}{c}(2) \\
\text { Full or } \\
\text { part-time } \\
\text { b/se }\end{array}$ & $\begin{array}{c}(3) \\
\text { Net monthly wages } \\
\mathrm{b} / \mathrm{se}\end{array}$ & $\begin{array}{c}(4) \\
\text { Multi-dimensional } \\
\text { Integration Index } \\
\mathrm{b} / \mathrm{se}\end{array}$ \\
\hline Unemployment rate t- 2 std. & $\begin{array}{l}-0.043^{* * *} \\
(0.013)\end{array}$ & $\begin{array}{l}-0.042^{* * *} \\
(0.012)\end{array}$ & $\begin{array}{l}-0.341^{* * *} \\
(0.103)\end{array}$ & $\begin{array}{l}-0.014^{* *} \\
(0.006)\end{array}$ \\
\hline Migrant Acceptance Index std. & $\begin{array}{l}0.050^{* * *} \\
(0.015)\end{array}$ & $\begin{array}{l}0.047^{* * *} \\
(0.012)\end{array}$ & $\begin{array}{l}0.178^{* *} \\
(0.083)\end{array}$ & $\begin{array}{c}0.011 \\
(0.007)\end{array}$ \\
\hline Female & $\begin{array}{l}-0.196^{* * *} \\
(0.016)\end{array}$ & $\begin{array}{l}-0.174^{* * *} \\
(0.015)\end{array}$ & $\begin{array}{l}-1.286^{* * *} \\
(0.118)\end{array}$ & $\begin{array}{l}-0.081^{* * *} \\
(0.006)\end{array}$ \\
\hline Secondary education & $\begin{array}{l}0.039^{* * *} \\
(0.008)\end{array}$ & $\begin{array}{l}0.021^{* * *} \\
(0.007)\end{array}$ & $\begin{array}{c}0.114 \\
(0.073)\end{array}$ & $\begin{array}{l}0.040^{* * *} \\
(0.006)\end{array}$ \\
\hline Tertiary education & $\begin{array}{l}0.061^{* * *} \\
(0.017)\end{array}$ & $\begin{array}{l}0.049^{* * *} \\
(0.014)\end{array}$ & $\begin{array}{l}0.391^{* *} \\
(0.171)\end{array}$ & $\begin{array}{l}0.065^{* * *} \\
(0.013)\end{array}$ \\
\hline Participated in integration course & $\begin{array}{c}0.002 \\
(0.021)\end{array}$ & $\begin{array}{l}-0.007 \\
(0.019)\end{array}$ & $\begin{array}{l}-0.004 \\
(0.139)\end{array}$ & $\begin{array}{l}0.041^{* * *} \\
(0.007)\end{array}$ \\
\hline German skills before emigration & $\begin{array}{c}0.051 \\
(0.060)\end{array}$ & $\begin{array}{l}-0.009 \\
(0.052)\end{array}$ & $\begin{array}{c}0.200 \\
(0.440)\end{array}$ & $\begin{array}{l}0.072^{* * *} \\
(0.018)\end{array}$ \\
\hline Help finding a job & $\begin{array}{l}0.179^{* * *} \\
(0.024)\end{array}$ & $\begin{array}{l}0.133^{* * *} \\
(0.020)\end{array}$ & $\begin{array}{l}1.357^{* * *} \\
(0.179)\end{array}$ & \\
\hline $\begin{array}{c}\text { Support from family \& friends } \\
\text { before emigration }\end{array}$ & $-0.028^{* *}$ & -0.018 & $-0.271^{* * *}$ & 0.002 \\
\hline & $(0.014)$ & $(0.015)$ & $(0.100)$ & $(0.005)$ \\
\hline Children in household & $\begin{array}{l}-0.074^{* * *} \\
(0.021)\end{array}$ & $\begin{array}{l}-0.075^{* * *} \\
(0.018)\end{array}$ & $\begin{array}{l}-0.604^{* * *} \\
(0.149)\end{array}$ & $\begin{array}{c}0.003 \\
(0.009)\end{array}$ \\
\hline Married/ In partnership & $\begin{array}{l}-0.044^{*} \\
(0.024)\end{array}$ & $\begin{array}{c}0.017 \\
(0.022)\end{array}$ & $\begin{array}{c}0.051 \\
(0.159)\end{array}$ & $\begin{array}{l}-0.024^{* *} \\
(0.009)\end{array}$ \\
\hline Satisfactory health status & $\begin{array}{l}0.061^{* * *} \\
(0.017)\end{array}$ & $\begin{array}{l}0.053^{* * *} \\
(0.014)\end{array}$ & $\begin{array}{l}0.277^{* *} \\
(0.120)\end{array}$ & $\begin{array}{l}0.044^{* * *} \\
(0.009)\end{array}$ \\
\hline Interview year FE & Yes & Yes & Yes & Yes \\
\hline Nuts-2 FE & Yes & Yes & Yes & Yes \\
\hline R-Squared & 0.229 & 0.205 & 0.228 & 0.253 \\
\hline $\mathrm{N}$ & 3170 & 2434 & 3013 & 2477 \\
\hline
\end{tabular}

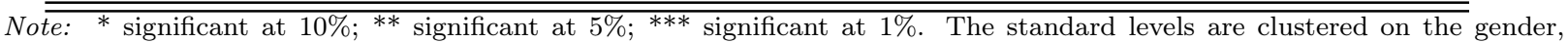
education, and state level $(\mathrm{G}=96$ clusters) and are displayed in parentheses. We pool observations from survey years 2016 to 2018 keeping only the most recent survey information. The sample is restricted to individuals with a minimum of two years of residence in Germany. Outcome variable "In employment or education" is one for refugees who report being in employment or education. Outcome variable "Full- or part-time employed" is one for refugees who report being in full- or part-time employment. Outcome "Net monthly wages" are net monthly wages, in inverse hyperbolic sine transformation. Table A15 includes the full set of covariates, as described in Section 4. For illustrative purposes, some control variables are not shown. Reference categories are as follows: primary education, aged 18-24 (aged 25-29 for full- or part-time employment), two years of residence in Germany, and Syrian origin. Information on attitudes stems from the European Social Survey. We merge natives' mean values on attitudes towards immigrants based on refugees' year of arrival and first state of residence in Germany. Source: IAB-BAMF-SOEP Survey of Refugees, v35 (2016-2018) and European Social Survey (2014). 
Table A16: Effect of unemployment and attitudes towards immigrants on the dimensions of the Multidimensional Integration Index, clustering standard errors on the gender, education, and state level

\begin{tabular}{|c|c|c|c|c|c|c|}
\hline & $\begin{array}{c}(1) \\
\text { Psychological } \\
\text { b/se }\end{array}$ & $\begin{array}{c}(2) \\
\text { Linguistic } \\
\text { b/se }\end{array}$ & $\begin{array}{c}(3) \\
\text { Economic } \\
\text { b/se }\end{array}$ & $\begin{array}{c}(4) \\
\text { Political } \\
\text { b/se }\end{array}$ & $\begin{array}{c}(5) \\
\text { Social } \\
\text { b/se }\end{array}$ & $\begin{array}{c}(6) \\
\text { Navigational } \\
\mathrm{b} / \mathrm{se}\end{array}$ \\
\hline Unemployment rate t- 2 std. & $\begin{array}{c}-0.001 \\
(0.018)\end{array}$ & $\begin{array}{l}-0.002 \\
(0.005)\end{array}$ & $\begin{array}{l}-0.036^{* *} \\
(0.017)\end{array}$ & $\begin{array}{c}0.001 \\
(0.006)\end{array}$ & $\begin{array}{l}-0.025^{*} \\
(0.014)\end{array}$ & $\begin{array}{l}-0.010 \\
(0.014)\end{array}$ \\
\hline Migrant Acceptance Index std. & $\begin{array}{l}0.016 \\
(0.015)\end{array}$ & $\begin{array}{l}-0.005 \\
(0.007)\end{array}$ & $\begin{array}{l}0.033^{* * *} \\
(0.011)\end{array}$ & $\begin{array}{l}-0.013 \\
(0.008)\end{array}$ & $\begin{array}{r}0.027^{*} \\
(0.015)\end{array}$ & $\begin{array}{l}-0.003 \\
(0.013)\end{array}$ \\
\hline Female & $\begin{array}{l}0.006 \\
(0.007)\end{array}$ & $\begin{array}{l}-0.071^{* * *} \\
(0.010)\end{array}$ & $\begin{array}{l}-0.213^{* * *} \\
(0.020)\end{array}$ & $\begin{array}{l}-0.007 \\
(0.005)\end{array}$ & $\begin{array}{l}-0.093^{* * *} \\
(0.011)\end{array}$ & $\begin{array}{l}-0.045^{* * *} \\
(0.011)\end{array}$ \\
\hline Secondary education & $\begin{array}{l}-0.010 \\
(0.011)\end{array}$ & $\begin{array}{l}0.122^{* * *} \\
(0.006)\end{array}$ & $\begin{array}{l}0.024^{* * *} \\
(0.009)\end{array}$ & $\begin{array}{c}0.006 \\
(0.005)\end{array}$ & $\begin{array}{l}0.059^{* * *} \\
(0.011)\end{array}$ & $\begin{array}{c}0.004 \\
(0.012)\end{array}$ \\
\hline Tertiary education & $\begin{array}{l}-0.032^{* *} \\
(0.016)\end{array}$ & $\begin{array}{l}0.240^{* * *} \\
(0.014)\end{array}$ & $\begin{array}{l}0.061^{* * *} \\
(0.022)\end{array}$ & $\begin{array}{c}0.011 \\
(0.007)\end{array}$ & $\begin{array}{l}0.042^{* *} \\
(0.016)\end{array}$ & $\begin{array}{c}0.026 \\
(0.021)\end{array}$ \\
\hline Participated in integration course & $\begin{array}{l}0.038^{* * *} \\
(0.010)\end{array}$ & $\begin{array}{l}0.072^{* * *} \\
(0.010)\end{array}$ & $\begin{array}{l}0.121^{* * *} \\
(0.017)\end{array}$ & $\begin{array}{l}-0.001 \\
(0.006)\end{array}$ & $\begin{array}{c}0.013 \\
(0.013)\end{array}$ & $\begin{array}{l}-0.018 \\
(0.012)\end{array}$ \\
\hline German skills before emigration & $\begin{array}{l}-0.007 \\
(0.027)\end{array}$ & $\begin{array}{l}0.109^{* * *} \\
(0.025)\end{array}$ & $\begin{array}{c}0.077 \\
(0.049)\end{array}$ & $\begin{array}{c}0.016 \\
(0.013)\end{array}$ & $\begin{array}{l}0.111^{* * *} \\
(0.032)\end{array}$ & $\begin{array}{c}0.062 \\
(0.043)\end{array}$ \\
\hline $\begin{array}{l}\text { Support from family \& friends } \\
\text { before emigration }\end{array}$ & $0.024^{* *}$ & -0.012 & -0.011 & 0.004 & -0.011 & 0.020 \\
\hline & $(0.011)$ & $(0.009)$ & $(0.015)$ & $(0.005)$ & $(0.012)$ & $(0.015)$ \\
\hline Children in household & $\begin{array}{l}0.053^{* * *} \\
(0.011)\end{array}$ & $\begin{array}{c}0.007 \\
(0.014)\end{array}$ & $\begin{array}{l}-0.071^{* * *} \\
(0.020)\end{array}$ & $\begin{array}{c}0.001 \\
(0.008)\end{array}$ & $\begin{array}{c}0.001 \\
(0.016)\end{array}$ & $\begin{array}{c}0.023 \\
(0.017)\end{array}$ \\
\hline Married/ In partnership & $\begin{array}{l}-0.003 \\
(0.012)\end{array}$ & $\begin{array}{l}-0.045^{* * *} \\
(0.012)\end{array}$ & $\begin{array}{l}-0.012 \\
(0.015)\end{array}$ & $\begin{array}{c}0.005 \\
(0.009)\end{array}$ & $\begin{array}{l}-0.046^{* *} \\
(0.017)\end{array}$ & $\begin{array}{l}-0.020 \\
(0.018)\end{array}$ \\
\hline Satisfactory health status & $\begin{array}{l}0.059^{* * *} \\
(0.013)\end{array}$ & $\begin{array}{l}0.052^{* * *} \\
(0.011)\end{array}$ & $\begin{array}{l}0.051^{* *} \\
(0.020)\end{array}$ & $\begin{array}{c}0.020^{*} \\
(0.011)\end{array}$ & $\begin{array}{l}0.062^{* * *} \\
(0.020)\end{array}$ & $\begin{array}{l}-0.017 \\
(0.018)\end{array}$ \\
\hline Interview year $\mathrm{FE}$ & Yes & Yes & Yes & Yes & Yes & Yes \\
\hline Nuts-2 FE & Yes & Yes & Yes & Yes & Yes & Yes \\
\hline R-Squared & 0.078 & 0.356 & 0.266 & 0.056 & 0.157 & 0.065 \\
\hline $\mathrm{N}$ & 2477 & 2477 & 2477 & 2477 & 2477 & 2477 \\
\hline
\end{tabular}

Note: ${ }^{*}$ significant at $10 \% ;{ }^{* *}$ significant at $5 \% ; * * *$ significant at $1 \%$. The standard levels are clustered on the gender, education, and state level $(\mathrm{G}=96$ clusters $)$ and are displayed in parentheses. We pool observations from survey years 2016 to 2018 keeping only the most recent survey information. The sample is restricted to individuals with a minimum of two years of residence in Germany. Dimensions are set similar to Harder et al. (2018). Table A16 includes the full set of covariates, as described in Section 4. For illustrative purposes, some control variables are not shown. Reference categories are as follows: primary education, aged 18-24, two years of residence in Germany, and Syrian origin. Information on attitudes stems from the European Social Survey. We merge natives' mean values on attitudes towards immigrants based on refugees' year of arrival and first state of residence in Germany. Source: IAB-BAMF-SOEP Survey of Refugees, v35 (2016-2018) and European Social Survey (2014). 
Table A17: Determinants of refugees' labor market and social outcomes, bootstrapped standard errors at the state level

\begin{tabular}{|c|c|c|c|c|}
\hline & $\begin{array}{c}(1) \\
\text { In employment } \\
\text { or education } \\
\text { b/se }\end{array}$ & $\begin{array}{c}(2) \\
\text { Full or } \\
\text { part-time } \\
\text { b/se }\end{array}$ & $\begin{array}{c}(3) \\
\text { Net monthly wages } \\
\mathrm{b} / \mathrm{se}\end{array}$ & $\begin{array}{c}(4) \\
\text { Multi-dimensional } \\
\text { Integration Index } \\
\mathrm{b} / \mathrm{se}\end{array}$ \\
\hline Unemployment rate t-2 std. & $\begin{array}{l}-0.043^{* * *} \\
(0.015)\end{array}$ & $\begin{array}{l}-0.042^{* * *} \\
(0.015)\end{array}$ & $\begin{array}{l}-0.341^{* * *} \\
(0.107)\end{array}$ & $\begin{array}{l}-0.014^{* *} \\
(0.006)\end{array}$ \\
\hline Migrant Acceptance Index std. & $\begin{array}{l}0.050^{* * *} \\
(0.014)\end{array}$ & $\begin{array}{l}0.047^{* * *} \\
(0.013)\end{array}$ & $\begin{array}{c}0.178^{*} \\
(0.097)\end{array}$ & $\begin{array}{l}0.011^{* *} \\
(0.005)\end{array}$ \\
\hline Female & $\begin{array}{l}-0.196^{* * *} \\
(0.015)\end{array}$ & $\begin{array}{l}-0.174^{* * *} \\
(0.015)\end{array}$ & $\begin{array}{l}-1.286^{* * *} \\
(0.094)\end{array}$ & $\begin{array}{l}-0.081^{* * *} \\
(0.006)\end{array}$ \\
\hline Secondary education & $\begin{array}{l}0.039^{* *} \\
(0.017)\end{array}$ & $\begin{array}{c}0.021 \\
(0.015)\end{array}$ & $\begin{array}{c}0.114 \\
(0.115)\end{array}$ & $\begin{array}{l}0.040^{* * *} \\
(0.007)\end{array}$ \\
\hline Tertiary education & $\begin{array}{l}0.061^{* *} \\
(0.026)\end{array}$ & $\begin{array}{r}0.049^{*} \\
(0.027)\end{array}$ & $\begin{array}{l}0.391^{* *} \\
(0.182)\end{array}$ & $\begin{array}{l}0.065^{* * *} \\
(0.009)\end{array}$ \\
\hline Participated in integration course & $\begin{array}{c}0.002 \\
(0.018)\end{array}$ & $\begin{array}{l}-0.007 \\
(0.019)\end{array}$ & $\begin{array}{l}-0.004 \\
(0.096)\end{array}$ & $\begin{array}{l}0.041^{* * *} \\
(0.005)\end{array}$ \\
\hline German skills before emigration & $\begin{array}{c}0.051 \\
(0.042)\end{array}$ & $\begin{array}{l}-0.009 \\
(0.040)\end{array}$ & $\begin{array}{c}0.200 \\
(0.384)\end{array}$ & $\begin{array}{l}0.072^{* * *} \\
(0.019)\end{array}$ \\
\hline Help finding a job & $\begin{array}{l}0.179^{* * *} \\
(0.022)\end{array}$ & $\begin{array}{l}0.133^{* * *} \\
(0.023)\end{array}$ & $\begin{array}{l}1.357^{* * *} \\
(0.180)\end{array}$ & \\
\hline $\begin{array}{l}\text { Support from family \& friends } \\
\text { before emigration }\end{array}$ & -0.028 & -0.018 & $-0.271^{* *}$ & 0.002 \\
\hline & $(0.018)$ & $(0.018)$ & $(0.120)$ & $(0.007)$ \\
\hline Children in household & $\begin{array}{l}-0.074^{* * *} \\
(0.021)\end{array}$ & $\begin{array}{l}-0.075^{* * *} \\
(0.018)\end{array}$ & $\begin{array}{l}-0.604^{* * *} \\
(0.146)\end{array}$ & $\begin{array}{c}0.003 \\
(0.009)\end{array}$ \\
\hline Married/ In partnership & $\begin{array}{l}-0.044^{* *} \\
(0.021)\end{array}$ & $\begin{array}{c}0.017 \\
(0.021)\end{array}$ & $\begin{array}{c}0.051 \\
(0.155)\end{array}$ & $\begin{array}{l}-0.024^{* * *} \\
(0.009)\end{array}$ \\
\hline Satisfactory health status & $\begin{array}{l}0.061^{* * *} \\
(0.023)\end{array}$ & $\begin{array}{l}0.053^{* * *} \\
(0.018)\end{array}$ & $\begin{array}{l}0.277^{* *} \\
(0.136)\end{array}$ & $\begin{array}{l}0.044^{* * *} \\
(0.011)\end{array}$ \\
\hline Interview year FE & Yes & Yes & Yes & Yes \\
\hline Nuts-2 FE & Yes & Yes & Yes & Yes \\
\hline R-Squared & 0.229 & 0.205 & 0.228 & 0.253 \\
\hline $\mathrm{N}$ & 3170 & 2434 & 3013 & 2477 \\
\hline
\end{tabular}

Note: ${ }^{*}$ significant at $10 \% ;{ }^{* *}$ significant at $5 \%{ }^{* * *}$ significant at 1\%. The standard levels are bootstrapped and are displayed in parentheses. We pool observations from survey years 2016 to 2018 keeping only the most recent survey information. The sample is restricted to individuals with a minimum of two years of residence in Germany. Outcome variable "In employment or education" is one for refugees who report being in employment or education. Outcome variable "Full- or part-time employed" is one for refugees who report being in full- or part-time employment. Outcome "Net monthly wages" are net monthly wages, in inverse hyperbolic sine transformation. Table A17 includes the full set of covariates, as described in Section 4. For illustrative purposes, some control variables are not shown. Reference categories are as follows: primary education, aged 18-24 (aged 25-29 for full- or part-time employment), two years of residence in Germany, and Syrian origin. Information on attitudes stems from the European Social Survey. We merge natives' mean values on attitudes towards immigrants based on refugees' year of arrival and first state of residence in Germany. Source: IAB-BAMF-SOEP Survey of Refugees, v35 (2016-2018) and European Social Survey (2014). 
Table A18: Effect of unemployment and attitudes towards immigrants on the dimensions of the Multidimensional Integration Index, bootstrapped standard errors at the state level

\begin{tabular}{|c|c|c|c|c|c|c|}
\hline & $\begin{array}{c}(1) \\
\text { Psychological } \\
\text { b/se }\end{array}$ & $\begin{array}{c}(2) \\
\text { Linguistic } \\
\text { b/se }\end{array}$ & $\begin{array}{c}(3) \\
\text { Economic } \\
\mathrm{b} / \mathrm{se}\end{array}$ & $\begin{array}{c}(4) \\
\text { Political } \\
\text { b/se }\end{array}$ & $\begin{array}{c}(5) \\
\text { Social } \\
\mathrm{b} / \mathrm{se}\end{array}$ & $\begin{array}{c}(6) \\
\text { Navigational } \\
\mathrm{b} / \mathrm{se}\end{array}$ \\
\hline Unemployment rate t-2 std. & $\begin{array}{l}-0.001 \\
(0.010)\end{array}$ & $\begin{array}{l}-0.002 \\
(0.009)\end{array}$ & $\begin{array}{l}-0.036^{* * *} \\
(0.013)\end{array}$ & $\begin{array}{c}0.001 \\
(0.005)\end{array}$ & $\begin{array}{l}-0.025^{* *} \\
(0.012)\end{array}$ & $\begin{array}{l}-0.010 \\
(0.011)\end{array}$ \\
\hline Migrant Acceptance Index std. & $\begin{array}{c}0.016 \\
(0.010)\end{array}$ & $\begin{array}{l}-0.005 \\
(0.008)\end{array}$ & $\begin{array}{l}0.033^{* * *} \\
(0.012)\end{array}$ & $\begin{array}{l}-0.013^{*} \\
(0.007)\end{array}$ & $\begin{array}{l}0.027^{* * *} \\
(0.010)\end{array}$ & $\begin{array}{l}-0.003 \\
(0.012)\end{array}$ \\
\hline Female & $\begin{array}{c}0.006 \\
(0.009)\end{array}$ & $\begin{array}{l}-0.071^{* * *} \\
(0.009)\end{array}$ & $\begin{array}{l}-0.213^{* * *} \\
(0.013)\end{array}$ & $\begin{array}{l}-0.007 \\
(0.006)\end{array}$ & $\begin{array}{l}-0.093^{* * *} \\
(0.013)\end{array}$ & $\begin{array}{l}-0.045^{* * *} \\
(0.011)\end{array}$ \\
\hline Secondary education & $\begin{array}{l}-0.010 \\
(0.010)\end{array}$ & $\begin{array}{l}0.122^{* * *} \\
(0.009)\end{array}$ & $\begin{array}{c}0.024 \\
(0.016)\end{array}$ & $\begin{array}{c}0.006 \\
(0.005)\end{array}$ & $\begin{array}{l}0.059^{* * *} \\
(0.014)\end{array}$ & $\begin{array}{c}0.004 \\
(0.012)\end{array}$ \\
\hline Tertiary education & $\begin{array}{l}-0.032^{* *} \\
(0.014)\end{array}$ & $\begin{array}{l}0.240^{* * *} \\
(0.013)\end{array}$ & $\begin{array}{l}0.061^{* * *} \\
(0.023)\end{array}$ & $\begin{array}{c}0.011 \\
(0.007)\end{array}$ & $\begin{array}{l}0.042^{* *} \\
(0.017)\end{array}$ & $\begin{array}{c}0.026 \\
(0.018)\end{array}$ \\
\hline Participated in integration course & $\begin{array}{l}0.038^{* * *} \\
(0.009)\end{array}$ & $\begin{array}{l}0.072^{* * *} \\
(0.009)\end{array}$ & $\begin{array}{l}0.121^{* * *} \\
(0.012)\end{array}$ & $\begin{array}{l}-0.001 \\
(0.005)\end{array}$ & $\begin{array}{c}0.013 \\
(0.011)\end{array}$ & $\begin{array}{l}-0.018 \\
(0.013)\end{array}$ \\
\hline German skills before emigration & $\begin{array}{l}-0.007 \\
(0.027)\end{array}$ & $\begin{array}{l}0.109^{* * *} \\
(0.025)\end{array}$ & $\begin{array}{c}0.077^{*} \\
(0.043)\end{array}$ & $\begin{array}{c}0.016 \\
(0.011)\end{array}$ & $\begin{array}{l}0.111^{* * *} \\
(0.029)\end{array}$ & $\begin{array}{c}0.062^{*} \\
(0.037)\end{array}$ \\
\hline $\begin{array}{l}\text { Support from family \& friends } \\
\text { before emigration }\end{array}$ & $0.024^{* *}$ & -0.012 & -0.011 & 0.004 & -0.011 & 0.020 \\
\hline & $(0.010)$ & $(0.010)$ & $(0.017)$ & $(0.006)$ & $(0.015)$ & $(0.015)$ \\
\hline Children in household & $\begin{array}{l}0.053^{* * *} \\
(0.012)\end{array}$ & $\begin{array}{c}0.007 \\
(0.013)\end{array}$ & $\begin{array}{l}-0.071^{* * *} \\
(0.017)\end{array}$ & $\begin{array}{c}0.001 \\
(0.007)\end{array}$ & $\begin{array}{c}0.001 \\
(0.018)\end{array}$ & $\begin{array}{c}0.023 \\
(0.015)\end{array}$ \\
\hline Married/ In partnership & $\begin{array}{l}-0.003 \\
(0.012)\end{array}$ & $\begin{array}{l}-0.045^{* * *} \\
(0.013)\end{array}$ & $\begin{array}{l}-0.012 \\
(0.020)\end{array}$ & $\begin{array}{c}0.005 \\
(0.008)\end{array}$ & $\begin{array}{l}-0.046^{* * *} \\
(0.017)\end{array}$ & $\begin{array}{l}-0.020 \\
(0.016)\end{array}$ \\
\hline Satisfactory health status & $\begin{array}{l}0.059^{* * *} \\
(0.015)\end{array}$ & $\begin{array}{l}0.052^{* * *} \\
(0.017)\end{array}$ & $\begin{array}{l}0.051^{* *} \\
(0.021)\end{array}$ & $\begin{array}{c}0.020^{*} \\
(0.012)\end{array}$ & $\begin{array}{l}0.062^{* * *} \\
(0.023)\end{array}$ & $\begin{array}{l}-0.017 \\
(0.021)\end{array}$ \\
\hline Interview year FE & Yes & Yes & Yes & Yes & Yes & Yes \\
\hline Nuts-2 FE & Yes & Yes & Yes & Yes & Yes & Yes \\
\hline R-squared & 0.078 & 0.356 & 0.266 & 0.056 & 0.157 & 0.065 \\
\hline $\mathrm{N}$ & 2477 & 2477 & 2477 & 2477 & 2477 & 2477 \\
\hline
\end{tabular}

Note: * significant at 10\%; ${ }^{* *}$ significant at 5\%; *** significant at 1\%. The standard levels are bootstrapped and are displayed in parentheses. We pool observations from survey years 2016 to 2018 keeping only the most recent survey information. The sample is restricted to individuals with a minimum of two years of residence in Germany. Dimensions are set similar to Harder et al. (2018). Table A18 includes the full set of covariates, as described in Section 4. For illustrative purposes, some control variables are not shown. Reference categories are as follows: primary education, aged 18-24, two years of residence in Germany, and Syrian origin. Information on attitudes stems from the European Social Survey. We merge natives' mean values on attitudes towards immigrants based on refugees' year of arrival and first state of residence in Germany. Source: IAB-BAMF-SOEP Survey of Refugees, v35 (2016-2018) and European Social Survey (2014). 
Table A19: Determinants of refugees' labor market and social outcomes, Conley standard errors

\begin{tabular}{|c|c|c|c|c|}
\hline & $\begin{array}{c}(1) \\
\text { In employment } \\
\text { or education } \\
\mathrm{b} / \mathrm{se}\end{array}$ & $\begin{array}{c}(2) \\
\text { Full or } \\
\text { part-time } \\
\text { b/se }\end{array}$ & $\begin{array}{c}(3) \\
\text { Net monthly wages } \\
\mathrm{b} / \mathrm{se}\end{array}$ & $\begin{array}{c}\text { Multi-dimensional } \\
\text { Integration Index } \\
\mathrm{b} / \mathrm{se}\end{array}$ \\
\hline \multirow[t]{2}{*}{ Unemployment rate t-2 std. } & $-0.043^{* * *}$ & $-0.042^{* * *}$ & $-0.341^{* * *}$ & $-0.014^{*}$ \\
\hline & $(0.011)$ & $(0.009)$ & $(0.086)$ & $(0.008)$ \\
\hline \multirow[t]{2}{*}{ Migrant Acceptance Index std. } & $0.050^{* * *}$ & $0.047^{* * *}$ & $0.178^{* *}$ & $0.011^{* *}$ \\
\hline & $(0.013)$ & $(0.012)$ & $(0.069)$ & $(0.005)$ \\
\hline \multirow[t]{2}{*}{ Female } & $-0.196^{* * *}$ & $-0.174^{* * *}$ & $-1.286^{* * *}$ & $-0.081^{* * *}$ \\
\hline & $(0.017)$ & $(0.010)$ & $(0.099)$ & $(0.007)$ \\
\hline \multirow[t]{2}{*}{ Secondary education } & $0.039^{* * *}$ & $0.021^{*}$ & 0.114 & $0.040^{* * *}$ \\
\hline & $(0.012)$ & $(0.012)$ & $(0.121)$ & $(0.006)$ \\
\hline \multirow[t]{2}{*}{ Tertiary education } & $0.061^{* * *}$ & $0.049^{* * *}$ & $0.391^{* *}$ & $0.065^{* * *}$ \\
\hline & $(0.019)$ & $(0.017)$ & $(0.157)$ & $(0.012)$ \\
\hline \multirow[t]{2}{*}{ Participated in integration course } & 0.002 & -0.007 & -0.004 & $0.041^{* * *}$ \\
\hline & $(0.017)$ & $(0.015)$ & $(0.108)$ & $(0.005)$ \\
\hline \multirow[t]{2}{*}{ German skills before emigration } & 0.051 & -0.009 & 0.200 & $0.072^{* * *}$ \\
\hline & $(0.064)$ & $(0.045)$ & $(0.514)$ & $(0.017)$ \\
\hline \multirow[t]{2}{*}{ Help finding a job } & $0.179^{* * *}$ & $0.133^{* * *}$ & $1.357^{* * *}$ & \\
\hline & $(0.016)$ & $(0.017)$ & $(0.159)$ & \\
\hline \multirow{2}{*}{$\begin{array}{l}\text { Support from family \& friends } \\
\text { before emigration }\end{array}$} & $-0.028^{*}$ & -0.018 & $-0.271^{* *}$ & 0.002 \\
\hline & $(0.016)$ & $(0.013)$ & $(0.117)$ & $(0.004)$ \\
\hline \multirow[t]{2}{*}{ Children in household } & $-0.074^{* * *}$ & $-0.075^{* * *}$ & $-0.604^{* * *}$ & 0.003 \\
\hline & $(0.019)$ & $(0.015)$ & $(0.130)$ & $(0.008)$ \\
\hline \multirow[t]{2}{*}{ Married/ In partnership } & $-0.044^{*}$ & 0.017 & 0.051 & $-0.024^{* * *}$ \\
\hline & $(0.022)$ & $(0.021)$ & $(0.126)$ & $(0.008)$ \\
\hline \multirow[t]{2}{*}{ Satisfactory health status } & $0.061^{* * *}$ & $0.053^{* * *}$ & $0.277^{* * *}$ & $0.044^{* * *}$ \\
\hline & $(0.013)$ & $(0.012)$ & $(0.107)$ & $(0.011)$ \\
\hline Interview year FE & Yes & Yes & Yes & Yes \\
\hline Nuts-2 FE & Yes & Yes & Yes & Yes \\
\hline R-Squared & 0.229 & 0.205 & 0.228 & 0.253 \\
\hline $\mathrm{N}$ & 3170 & 2434 & 3013 & 2477 \\
\hline
\end{tabular}

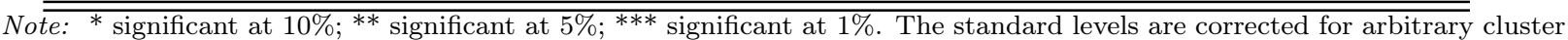
correlation in spatial settings (acreg) and are displayed in parentheses. We pool observations from survey years 2016 to 2018 keeping only the most recent survey information. The sample is restricted to individuals with a minimum of two years of residence in Germany. Outcome variable "In employment or education" is one for refugees who report being in employment or education. Outcome variable "Full- or part-time employed" is one for refugees who report being in full- or part-time employment. Outcome "Net monthly wages" are net monthly wages, in inverse hyperbolic sine transformation. Table A19 includes the full set of covariates, as described in Section 4. For illustrative purposes, some control variables are not shown. Reference categories are as follows: primary education, aged 18-24 (aged 25-29 for full- or part-time employment), two years of residence in Germany, and Syrian origin. Information on attitudes stems from the European Social Survey. We merge natives' mean values on attitudes towards immigrants based on refugees' year of arrival and first state of residence in Germany. Source: IAB-BAMF-SOEP Survey of Refugees, v35 (2016-2018) and European Social Survey (2014). 
Table A20: Effect of unemployment and attitudes towards immigrants on the dimensions of the Multi-dimensional Integration Index, Conley standard errors

\begin{tabular}{|c|c|c|c|c|c|c|}
\hline & $\begin{array}{c}(1) \\
\text { Psychological } \\
\text { b/se }\end{array}$ & $\begin{array}{c}(2) \\
\text { Linguistic } \\
\text { b/se }\end{array}$ & $\begin{array}{c}(3) \\
\text { Economic } \\
\text { b/se }\end{array}$ & $\begin{array}{c}(4) \\
\text { Political } \\
\text { b/se }\end{array}$ & $\begin{array}{c}(5) \\
\text { Social } \\
\mathrm{b} / \mathrm{se}\end{array}$ & $\begin{array}{c}(6) \\
\text { Navigational } \\
\mathrm{b} / \mathrm{se}\end{array}$ \\
\hline Unemployment rate t- 2 std. & $\begin{array}{l}-0.001 \\
(0.015)\end{array}$ & $\begin{array}{l}-0.002 \\
(0.007)\end{array}$ & $\begin{array}{l}-0.036^{* *} \\
(0.015)\end{array}$ & $\begin{array}{c}0.001 \\
(0.005)\end{array}$ & $\begin{array}{l}-0.025 \\
(0.016)\end{array}$ & $\begin{array}{l}-0.010 \\
(0.013)\end{array}$ \\
\hline Migrant Acceptance Index std. & $\begin{array}{c}0.016 \\
(0.013)\end{array}$ & $\begin{array}{l}-0.005 \\
(0.005)\end{array}$ & $\begin{array}{l}0.033^{* * *} \\
(0.010)\end{array}$ & $\begin{array}{l}-0.013 \\
(0.008)\end{array}$ & $\begin{array}{l}0.027^{* *} \\
(0.013)\end{array}$ & $\begin{array}{l}-0.003 \\
(0.011)\end{array}$ \\
\hline Female & $\begin{array}{c}0.006 \\
(0.009)\end{array}$ & $\begin{array}{l}-0.071^{* * *} \\
(0.008)\end{array}$ & $\begin{array}{l}-0.213^{* * *} \\
(0.016)\end{array}$ & $\begin{array}{l}-0.007 \\
(0.005)\end{array}$ & $\begin{array}{l}-0.093^{* * *} \\
(0.010)\end{array}$ & $\begin{array}{l}-0.045^{* * *} \\
(0.011)\end{array}$ \\
\hline Secondary education & $\begin{array}{l}-0.010 \\
(0.013)\end{array}$ & $\begin{array}{l}0.122^{* * *} \\
(0.007)\end{array}$ & $\begin{array}{l}0.024^{* *} \\
(0.011)\end{array}$ & $\begin{array}{c}0.006 \\
(0.006)\end{array}$ & $\begin{array}{l}0.059^{* * *} \\
(0.013)\end{array}$ & $\begin{array}{c}0.004 \\
(0.017)\end{array}$ \\
\hline Tertiary education & $\begin{array}{l}-0.032^{*} \\
(0.018)\end{array}$ & $\begin{array}{l}0.240^{* * *} \\
(0.011)\end{array}$ & $\begin{array}{l}0.061^{* * *} \\
(0.019)\end{array}$ & $\begin{array}{l}0.011^{* *} \\
(0.005)\end{array}$ & $\begin{array}{l}0.042^{* *} \\
(0.017)\end{array}$ & $\begin{array}{c}0.026 \\
(0.020)\end{array}$ \\
\hline Participated in integration course & $\begin{array}{l}0.038^{* * *} \\
(0.012)\end{array}$ & $\begin{array}{l}0.072^{* * *} \\
(0.009)\end{array}$ & $\begin{array}{l}0.121^{* * *} \\
(0.014)\end{array}$ & $\begin{array}{l}-0.001 \\
(0.007)\end{array}$ & $\begin{array}{c}0.013 \\
(0.011)\end{array}$ & $\begin{array}{l}-0.018 \\
(0.012)\end{array}$ \\
\hline German skills before emigration & $\begin{array}{l}-0.007 \\
(0.028)\end{array}$ & $\begin{array}{l}0.109^{* * *} \\
(0.020)\end{array}$ & $\begin{array}{c}0.077 \\
(0.052)\end{array}$ & $\begin{array}{c}0.016 \\
(0.010)\end{array}$ & $\begin{array}{l}0.111^{* * *} \\
(0.028)\end{array}$ & $\begin{array}{c}0.062 \\
(0.045)\end{array}$ \\
\hline $\begin{array}{l}\text { Support from family \& friends } \\
\text { before emigration }\end{array}$ & $0.024^{* *}$ & -0.012 & -0.011 & 0.004 & -0.011 & 0.020 \\
\hline & $(0.009)$ & $(0.010)$ & $(0.018)$ & $(0.007)$ & $(0.014)$ & $(0.014)$ \\
\hline Children in household & $\begin{array}{l}0.053^{* * *} \\
(0.008)\end{array}$ & $\begin{array}{c}0.007 \\
(0.014)\end{array}$ & $\begin{array}{l}-0.071^{* * *} \\
(0.016)\end{array}$ & $\begin{array}{c}0.001 \\
(0.008)\end{array}$ & $\begin{array}{c}0.001 \\
(0.020)\end{array}$ & $\begin{array}{c}0.023 \\
(0.019)\end{array}$ \\
\hline Married/ In partnership & $\begin{array}{l}-0.003 \\
(0.015)\end{array}$ & $\begin{array}{l}-0.045^{* * *} \\
(0.010)\end{array}$ & $\begin{array}{l}-0.012 \\
(0.010)\end{array}$ & $\begin{array}{c}0.005 \\
(0.010)\end{array}$ & $\begin{array}{l}-0.046^{* * *} \\
(0.017)\end{array}$ & $\begin{array}{l}-0.020 \\
(0.018)\end{array}$ \\
\hline Satisfactory health status & $\begin{array}{l}0.059^{* * *} \\
(0.015)\end{array}$ & $\begin{array}{l}0.052^{* * *} \\
(0.012)\end{array}$ & $\begin{array}{l}0.051^{\text {*** }} \\
(0.018)\end{array}$ & $\begin{array}{l}0.020^{* *} \\
(0.008)\end{array}$ & $\begin{array}{l}0.062^{* * *} \\
(0.023)\end{array}$ & $\begin{array}{l}-0.017 \\
(0.023)\end{array}$ \\
\hline Interview year FE & Yes & Yes & Yes & Yes & Yes & Yes \\
\hline Nuts-2 FE & Yes & Yes & Yes & Yes & Yes & Yes \\
\hline R-Squared & 0.078 & 0.356 & 0.266 & 0.056 & 0.157 & 0.065 \\
\hline $\mathrm{N}$ & 2477 & 2477 & 2477 & 2477 & 2477 & 2477 \\
\hline
\end{tabular}

Note: ${ }^{*}$ significant at $10 \% ;{ }^{* *}$ significant at $5 \%{ }^{* * *}$ significant at $1 \%$. The standard levels are corrected for arbitrary cluster correlation in spatial settings (acreg) and are displayed in parentheses. We pool observations from survey years 2016 to 2018 keeping only the most recent survey information. The sample is restricted to individuals with a minimum of two years of residence in Germany. Dimensions are set similar to Harder et al. (2018). Table A20 includes the full set of covariates, as described in Section 4. For illustrative purposes, some control variables are not shown. Reference categories are as follows: primary education, aged 18-24, two years of residence in Germany, and Syrian origin. Information on attitudes stems from the European Social Survey. We merge natives' mean values on attitudes towards immigrants based on refugees' year of arrival and first state of residence in Germany. Source: IAB-BAMF-SOEP Survey of Refugees, v35 (2016-2018) and European Social Survey (2014). 
Table A21: Determinants of refugees' labor market outcomes, dropping potentially "bad controls"

\begin{tabular}{lcccc}
\hline \hline & $(1)$ & $(2)$ & $(3)$ & $(4)$ \\
& $\begin{array}{c}\text { In employment } \\
\text { or education } \\
\mathrm{b} / \mathrm{se}\end{array}$ & $\begin{array}{c}\text { Full or } \\
\text { part-time } \\
\mathrm{b} / \mathrm{se}\end{array}$ & $\begin{array}{c}\text { Net monthly wages } \\
\text { b/se }\end{array}$ & $\begin{array}{c}\text { Multi-dimensional } \\
\text { Integration Index } \\
\mathrm{b} / \mathrm{se}\end{array}$ \\
\hline Unemployment rate t-2 std. & $-0.047^{* * *}$ & $-0.045^{* * *}$ & $-0.373^{* * *}$ & $-0.013^{* *}$ \\
Migrant Acceptance Index std. & $(0.013)$ & $(0.012)$ & $(0.090)$ & $(0.007)$ \\
& $0.050^{* * *}$ & $0.047^{* * *}$ & $0.188^{*}$ & $0.011^{*}$ \\
Female & $(0.017)$ & $(0.013)$ & $(0.097)$ & $(0.006)$ \\
& $-0.234^{* * *}$ & $-0.206^{* * *}$ & $-1.562^{* * *}$ & $-0.087^{* * *}$ \\
Secondary education & $(0.015)$ & $(0.014)$ & $(0.095)$ & $(0.005)$ \\
& $0.046^{* * *}$ & 0.025 & 0.166 & $0.047^{* * *}$ \\
Tertiary education & $(0.015)$ & $(0.015)$ & $(0.105)$ & $(0.007)$ \\
& $0.086^{* * *}$ & $0.069^{* * *}$ & $0.595^{* * *}$ & $0.076^{* * *}$ \\
Married/ In partnership & $(0.021)$ & $(0.022)$ & $(0.163)$ & $(0.010)$ \\
& $-0.095^{* * *}$ & -0.031 & $-0.350^{* *}$ & $-0.025^{* * *}$ \\
Interview year FE & $(0.018)$ & $(0.021)$ & $(0.135)$ & $(0.008)$ \\
Nuts-2 FE & Yes & Yes & Yes & Yes \\
\hline R-Squared & Yes & Yes & Yes & 0.223 \\
N & 0.201 & 0.177 & 0.192 & 2477 \\
\hline \hline
\end{tabular}

Note: ${ }^{*}$ significant at $10 \% ;{ }^{* *}$ significant at $5 \% ;{ }^{* * *}$ significant at $1 \%$. The standard levels are clustered on the county level and are displayed in parentheses. We pool observations from survey years 2016 to 2018 keeping only the most recent survey information. The sample is restricted to individuals with a minimum of two years of residence in Germany. Table A21 includes a minimum of control variables, including information on gender, education, country of origin, age, years of residence in Germany, and family status. Outcome variable "In employment or education" is one for refugees who report being in employment or education. Outcome variable "Full- or part-time employed" is one for refugees who report being in full- or part-time employment. Outcome "Net monthly wages" are net monthly wages, in inverse hyperbolic sine transformation. Reference categories are as follows: primary education, aged 18-24 (aged 25-29 for full- or part-time employment), two years of residence in Germany, and Syrian origin. Information on attitudes stems from the European Social Survey. We merge natives' mean values on attitudes towards immigrants based on refugees' year of arrival and first state of residence in Germany. Source: IAB-BAMF-SOEP Survey of Refugees, v35 (2016-2018) and European Social Survey (2014). 
Table A22: Determinants of refugees' labor market outcomes, including control variables for type of residence status

\begin{tabular}{|c|c|c|c|c|}
\hline & $\begin{array}{c}(1) \\
\text { In employment } \\
\text { or education } \\
\text { b/se }\end{array}$ & $\begin{array}{c}(2) \\
\text { Full or } \\
\text { part-time } \\
\text { b/se }\end{array}$ & $\begin{array}{c}(3) \\
\text { Net monthly wages } \\
\mathrm{b} / \mathrm{se}\end{array}$ & $\begin{array}{c}(4) \\
\text { Multi-dimensional } \\
\text { Integration Index } \\
\mathrm{b} / \mathrm{se}\end{array}$ \\
\hline Unemployment rate t-2 std. & $\begin{array}{l}-0.048^{* * *} \\
(0.013)\end{array}$ & $\begin{array}{l}-0.043^{* * *} \\
(0.012)\end{array}$ & $\begin{array}{l}-0.360^{* * *} \\
(0.086)\end{array}$ & $\begin{array}{l}-0.014^{* *} \\
(0.007)\end{array}$ \\
\hline Migrant Acceptance Index std. & $\begin{array}{l}0.051^{* * *} \\
(0.017)\end{array}$ & $\begin{array}{l}0.048^{* * *} \\
(0.013)\end{array}$ & $\begin{array}{l}0.190^{* *} \\
(0.094)\end{array}$ & $\begin{array}{c}0.012^{*} \\
(0.006)\end{array}$ \\
\hline Female & $\begin{array}{l}-0.200^{* * *} \\
(0.015)\end{array}$ & $\begin{array}{l}-0.176^{* * *} \\
(0.013)\end{array}$ & $\begin{array}{l}-1.299^{* * *} \\
(0.094)\end{array}$ & $\begin{array}{l}-0.082^{* * *} \\
(0.005)\end{array}$ \\
\hline Secondary education & $\begin{array}{l}0.039^{* *} \\
(0.015)\end{array}$ & $\begin{array}{l}0.020 \\
(0.015)\end{array}$ & $\begin{array}{c}0.114 \\
(0.107)\end{array}$ & $\begin{array}{l}0.040^{* * *} \\
(0.007)\end{array}$ \\
\hline Tertiary education & $\begin{array}{l}0.058^{* * *} \\
(0.022)\end{array}$ & $\begin{array}{l}0.043^{* *} \\
(0.021)\end{array}$ & $\begin{array}{l}0.365^{* *} \\
(0.156)\end{array}$ & $\begin{array}{l}0.064^{* * *} \\
(0.010)\end{array}$ \\
\hline Participated in integration course & $\begin{array}{c}0.003 \\
(0.018)\end{array}$ & $\begin{array}{l}-0.007 \\
(0.016)\end{array}$ & $\begin{array}{l}-0.003 \\
(0.111)\end{array}$ & $\begin{array}{l}0.039^{* * *} \\
(0.006)\end{array}$ \\
\hline German skills before emigration & $\begin{array}{c}0.056 \\
(0.048)\end{array}$ & $\begin{array}{l}-0.004 \\
(0.042)\end{array}$ & $\begin{array}{c}0.224 \\
(0.371)\end{array}$ & $\begin{array}{l}0.073^{* * *} \\
(0.017)\end{array}$ \\
\hline Help finding a job & $\begin{array}{l}0.176^{* * *} \\
(0.023)\end{array}$ & $\begin{array}{l}0.131^{* * *} \\
(0.023)\end{array}$ & $\begin{array}{l}1.359^{* * *} \\
(0.181)\end{array}$ & \\
\hline $\begin{array}{c}\text { Support from family \& friends } \\
\text { before emigration }\end{array}$ & -0.022 & -0.015 & $-0.242^{*}$ & 0.003 \\
\hline & $(0.018)$ & $(0.018)$ & $(0.127)$ & $(0.007)$ \\
\hline Children in household & $\begin{array}{l}-0.076^{* * *} \\
(0.019)\end{array}$ & $\begin{array}{l}-0.075^{* * *} \\
(0.019)\end{array}$ & $\begin{array}{l}-0.619^{* * *} \\
(0.139)\end{array}$ & $\begin{array}{c}0.002 \\
(0.009)\end{array}$ \\
\hline Married/ In partnership & $\begin{array}{l}-0.037^{*} \\
(0.021)\end{array}$ & $\begin{array}{c}0.020 \\
(0.023)\end{array}$ & $\begin{array}{c}0.084 \\
(0.153)\end{array}$ & $\begin{array}{l}-0.025^{* * *} \\
(0.008)\end{array}$ \\
\hline Satisfactory health status & $\begin{array}{l}0.057^{* * *} \\
(0.021)\end{array}$ & $\begin{array}{l}0.049^{* * *} \\
(0.016)\end{array}$ & $\begin{array}{c}0.248^{*} \\
(0.128)\end{array}$ & $\begin{array}{l}0.042^{\text {*** }} \\
(0.009)\end{array}$ \\
\hline Asylum seeker & $\begin{array}{l}-0.028 \\
(0.021)\end{array}$ & $\begin{array}{l}-0.036^{*} \\
(0.021)\end{array}$ & $\begin{array}{c}-0.170 \\
(0.152)\end{array}$ & $\begin{array}{l}-0.013 \\
(0.009)\end{array}$ \\
\hline Tolerated foreigner & $\begin{array}{l}-0.006 \\
(0.020)\end{array}$ & $\begin{array}{l}-0.037^{*} \\
(0.021)\end{array}$ & $\begin{array}{l}-0.195 \\
(0.131)\end{array}$ & $\begin{array}{l}-0.016^{*} \\
(0.009)\end{array}$ \\
\hline Other residence status & $\begin{array}{l}-0.014 \\
(0.024)\end{array}$ & $\begin{array}{c}-0.021 \\
(0.024)\end{array}$ & $\begin{array}{l}-0.105 \\
(0.170)\end{array}$ & $\begin{array}{l}-0.019 * \\
(0.010)\end{array}$ \\
\hline Interview year $\mathrm{FE}$ & Yes & Yes & Yes & Yes \\
\hline Nuts-2 FE & Yes & Yes & Yes & Yes \\
\hline R-Squared & 0.232 & 0.207 & 0.231 & 0.256 \\
\hline $\mathrm{N}$ & 3121 & 2398 & 2966 & 2445 \\
\hline
\end{tabular}

Note: ${ }^{*}$ significant at $10 \% ;{ }^{* *}$ significant at $5 \% ;{ }^{* * *}$ significant at $1 \%$. The standard levels are clustered on the county level and are displayed in parentheses. We pool observations from survey years 2016 to 2018 keeping only the most recent survey information. The sample is restricted to individuals with a minimum of two years of residence in Germany. Outcome variable "In employment or education" is one for refugees who report being in employment or education. Outcome variable "Full- or part-time employed" is one for refugees who report being in full- or part-time employment. Outcome "Net monthly wages" are net monthly wages, in inverse hyperbolic sine transformation. Table A22 includes the full set of covariates, as described in Section 4. For illustrative purposes, some control variables are not shown. Reference categories are as follows: primary education, aged 18-24 (aged 25-29 for full- or part-time employment), two years of residence in Germany, positive asylum decision, and Syrian origin. Information on attitudes stems from the European Social Survey. We merge natives' mean values on attitudes towards immigrants based on refugees' year of arrival and first state of residence in Germany. Source: IAB-BAMF-SOEP Survey of Refugees, v35 (2016-2018) and European Social Survey (2014). 
Table A23: Determinants of refugees' labor market outcomes, without regional fixed effects

\begin{tabular}{|c|c|c|c|c|}
\hline & $\begin{array}{c}(1) \\
\text { In employment } \\
\text { or education } \\
\text { b/se }\end{array}$ & $\begin{array}{c}(2) \\
\text { Full or } \\
\text { part-time } \\
\text { b/se }\end{array}$ & $\begin{array}{c}(3) \\
\text { Net monthly wages } \\
\text { b/se }\end{array}$ & $\begin{array}{c}(4) \\
\text { Multi-dimensional } \\
\text { Integration Index } \\
\mathrm{b} / \mathrm{se}\end{array}$ \\
\hline Unemployment rate t-2 std. & $\begin{array}{l}-0.033^{* * *} \\
(0.008)\end{array}$ & $\begin{array}{l}-0.034^{* * *} \\
(0.008)\end{array}$ & $\begin{array}{l}-0.339^{* * *} \\
(0.068)\end{array}$ & $\begin{array}{l}-0.021^{* * *} \\
(0.005)\end{array}$ \\
\hline Migrant Acceptance Index std. & $\begin{array}{l}0.030^{* * *} \\
(0.007)\end{array}$ & $\begin{array}{c}0.007 \\
(0.007)\end{array}$ & $\begin{array}{c}0.083^{*} \\
(0.049)\end{array}$ & $\begin{array}{c}0.005 \\
(0.006)\end{array}$ \\
\hline Female & $\begin{array}{l}-0.195^{* * *} \\
(0.014)\end{array}$ & $\begin{array}{l}-0.177^{* * *} \\
(0.013)\end{array}$ & $\begin{array}{l}-1.281^{* * *} \\
(0.089)\end{array}$ & $\begin{array}{l}-0.080^{* * *} \\
(0.005)\end{array}$ \\
\hline Secondary education & $\begin{array}{l}0.043^{* * *} \\
(0.015)\end{array}$ & $\begin{array}{c}0.026^{*} \\
(0.015)\end{array}$ & $\begin{array}{c}0.140 \\
(0.108)\end{array}$ & $\begin{array}{l}0.038^{* * *} \\
(0.007)\end{array}$ \\
\hline Tertiary education & $\begin{array}{l}0.064^{* * *} \\
(0.021)\end{array}$ & $\begin{array}{l}0.052^{* *} \\
(0.021)\end{array}$ & $\begin{array}{l}0.431^{* * *} \\
(0.156)\end{array}$ & $\begin{array}{l}0.068^{* * *} \\
(0.010)\end{array}$ \\
\hline Participated in integration course & $\begin{array}{c}0.003 \\
(0.017)\end{array}$ & $\begin{array}{l}-0.004 \\
(0.016)\end{array}$ & $\begin{array}{c}0.002 \\
(0.109)\end{array}$ & $\begin{array}{l}0.043^{* * *} \\
(0.006)\end{array}$ \\
\hline German skills before emigration & $\begin{array}{c}0.051 \\
(0.049)\end{array}$ & $\begin{array}{l}-0.006 \\
(0.045)\end{array}$ & $\begin{array}{c}0.207 \\
(0.379)\end{array}$ & $\begin{array}{l}0.066^{* * *} \\
(0.018)\end{array}$ \\
\hline Help finding a job & $\begin{array}{l}0.178^{* * *} \\
(0.023)\end{array}$ & $\begin{array}{l}0.133^{* * *} \\
(0.022)\end{array}$ & $\begin{array}{l}1.355^{* * *} \\
(0.179)\end{array}$ & \\
\hline $\begin{array}{l}\text { Support from family \& friends } \\
\text { before emigration }\end{array}$ & $-0.031^{*}$ & -0.023 & $-0.299 * *$ & -0.000 \\
\hline & $(0.018)$ & $(0.018)$ & $(0.126)$ & $(0.007)$ \\
\hline Children in household & $\begin{array}{l}-0.071^{* * *} \\
(0.019)\end{array}$ & $\begin{array}{l}-0.072^{* * *} \\
(0.018)\end{array}$ & $\begin{array}{l}-0.561^{* * *} \\
(0.134)\end{array}$ & $\begin{array}{c}0.005 \\
(0.009)\end{array}$ \\
\hline Married/ In partnership & $\begin{array}{l}-0.043^{* *} \\
(0.021)\end{array}$ & $\begin{array}{c}0.020 \\
(0.023)\end{array}$ & $\begin{array}{c}0.063 \\
(0.150)\end{array}$ & $\begin{array}{l}-0.026^{* * *} \\
(0.008)\end{array}$ \\
\hline Satisfactory health status & $\begin{array}{l}0.063^{* * *} \\
(0.021)\end{array}$ & $\begin{array}{l}0.055^{* * *} \\
(0.018)\end{array}$ & $\begin{array}{l}0.293^{* *} \\
(0.128)\end{array}$ & $\begin{array}{l}0.046^{* * *} \\
(0.010)\end{array}$ \\
\hline Interview year FE & Yes & Yes & Yes & Yes \\
\hline R-Squared & 0.218 & 0.183 & 0.215 & 0.219 \\
\hline $\mathrm{N}$ & 3170 & 2434 & 3013 & 2477 \\
\hline
\end{tabular}

Note: ${ }^{*}$ significant at 10\%; ${ }^{* *}$ significant at $5 \% ;{ }^{* *}$ significant at $1 \%$. The standard levels are clustered on the county level and are displayed in parentheses. We pool observations from survey years 2016 to 2018 keeping only the most recent survey information. The sample is restricted to individuals with a minimum of two years of residence in Germany. Outcome variable "In employment or education" is one for refugees who report being in employment or education. Outcome variable "Full- or part-time employed" is one for refugees who report being in full- or part-time employment. Outcome "Net monthly wages" are net monthly wages, in inverse hyperbolic sine transformation. Table A23 includes the full set of covariates, as described in Section 4. For illustrative purposes, some control variables are not shown. Reference categories are as follows: primary education, aged 18-24 (aged 25-29 for full- or part-time employment), two years of residence in Germany, positive asylum decision, and Syrian origin. Information on attitudes stems from the European Social Survey. We merge natives' mean values on attitudes towards immigrants based on refugees' year of arrival and first state of residence in Germany. Source: IAB-BAMF-SOEP Survey of Refugees, v35 (2016-2018) and European Social Survey (2014). 
Table A24: Determinants of refugees' labor market outcomes in states with strict residency requirements

\begin{tabular}{|c|c|c|c|c|}
\hline & $\begin{array}{c}(1) \\
\text { In employment } \\
\text { or education } \\
\mathrm{b} / \mathrm{se}\end{array}$ & $\begin{array}{c}(2) \\
\text { Full or } \\
\text { part-time } \\
\text { b/se }\end{array}$ & $\begin{array}{c}(3) \\
\text { Net monthly wages } \\
\mathrm{b} / \mathrm{se}\end{array}$ & $\begin{array}{c}(4) \\
\text { Multi-dimensional } \\
\text { Integration Index } \\
\mathrm{b} / \mathrm{se}\end{array}$ \\
\hline \multirow[t]{2}{*}{ Unemployment rate t-2 std. } & $-0.031^{*}$ & $-0.044^{* * *}$ & $-0.188^{*}$ & -0.010 \\
\hline & $(0.017)$ & $(0.017)$ & $(0.103)$ & $(0.008)$ \\
\hline \multirow[t]{2}{*}{ Migrant Acceptance Index std. } & $0.062^{* * *}$ & $0.063^{* * *}$ & $0.268^{* *}$ & $0.017^{* *}$ \\
\hline & $(0.019)$ & $(0.019)$ & $(0.114)$ & $(0.008)$ \\
\hline \multirow[t]{2}{*}{ Female } & $-0.211^{* * *}$ & $-0.185^{* * *}$ & $-1.318^{* * *}$ & $-0.086^{* * *}$ \\
\hline & $(0.018)$ & $(0.018)$ & $(0.117)$ & $(0.007)$ \\
\hline \multirow[t]{2}{*}{ Secondary education } & $0.032^{*}$ & 0.023 & 0.037 & $0.037^{* * *}$ \\
\hline & $(0.019)$ & $(0.019)$ & $(0.129)$ & $(0.009)$ \\
\hline \multirow[t]{2}{*}{ Tertiary education } & $0.045^{*}$ & 0.033 & 0.199 & $0.045^{* * *}$ \\
\hline & $(0.026)$ & $(0.026)$ & $(0.184)$ & $(0.012)$ \\
\hline \multirow[t]{2}{*}{ Participated in integration course } & -0.015 & -0.017 & -0.052 & $0.042^{* * *}$ \\
\hline & $(0.023)$ & $(0.023)$ & $(0.154)$ & $(0.008)$ \\
\hline \multirow[t]{2}{*}{ German skills before emigration } & $0.167^{* *}$ & 0.048 & 0.879 & $0.075^{* * *}$ \\
\hline & $(0.066)$ & $(0.059)$ & $(0.552)$ & $(0.024)$ \\
\hline \multirow[t]{2}{*}{ Help finding a job } & $0.199^{* * *}$ & $0.156^{* * *}$ & $1.671^{* * *}$ & \\
\hline & $(0.026)$ & $(0.029)$ & $(0.219)$ & \\
\hline \multirow{2}{*}{$\begin{array}{l}\text { Support from family \& friends } \\
\text { before emigration }\end{array}$} & -0.018 & -0.001 & -0.195 & 0.009 \\
\hline & $(0.024)$ & $(0.023)$ & $(0.164)$ & $(0.009)$ \\
\hline \multirow[t]{2}{*}{ Children in household } & $-0.060^{* *}$ & $-0.080 * * *$ & $-0.650 * * *$ & 0.003 \\
\hline & $(0.026)$ & $(0.027)$ & $(0.181)$ & $(0.011)$ \\
\hline \multirow[t]{2}{*}{ Married/ In partnership } & $-0.062^{* *}$ & -0.019 & -0.139 & $-0.037 * * *$ \\
\hline & $(0.029)$ & $(0.028)$ & $(0.209)$ & $(0.011)$ \\
\hline \multirow[t]{2}{*}{ Satisfactory health status } & $0.054^{*}$ & $0.066^{* * *}$ & $0.285^{*}$ & $0.029^{* *}$ \\
\hline & $(0.028)$ & $(0.024)$ & $(0.170)$ & $(0.014)$ \\
\hline Interview year FE & Yes & Yes & Yes & Yes \\
\hline Nuts-2 FE & Yes & Yes & Yes & Yes \\
\hline R-Squared & 0.242 & 0.228 & 0.247 & 0.243 \\
\hline $\mathrm{N}$ & 1889 & 1476 & 1792 & 1496 \\
\hline
\end{tabular}

Note: ${ }^{*}$ significant at 10\%; ${ }^{* *}$ significant at 5\%; ${ }^{* *}$ significant at 1\%. The standard levels are clustered on the county level and are displayed in parentheses. We pool observations from survey years 2016 to 2018 keeping only the most recent survey information. The sample is restricted to individuals with a minimum of two years of residence in Germany. Outcome variable "In employment or education" is one for refugees who report being in employment or education. Outcome variable "Full- or part-time employed" is one for refugees who report being in full- or part-time employment. Outcome "Net monthly wages" are net monthly wages, in inverse hyperbolic sine transformation. Table A24 includes the full set of covariates, as described in Section 4. For illustrative purposes, some control variables are not shown. Reference categories are as follows: primary education, aged 18-24 (aged 25-29 for full- or part-time employment), two years of residence in Germany, positive asylum decision, and Syrian origin. Information on attitudes stems from the European Social Survey. We merge natives' mean values on attitudes towards immigrants based on refugees' year of arrival and first state of residence in Germany. Source: IAB-BAMF-SOEP Survey of Refugees, v35 (2016-2018) and European Social Survey (2014). 
B Appendix Figures 
Figure A1: Number of refugees per county, disaggregated by country of origin
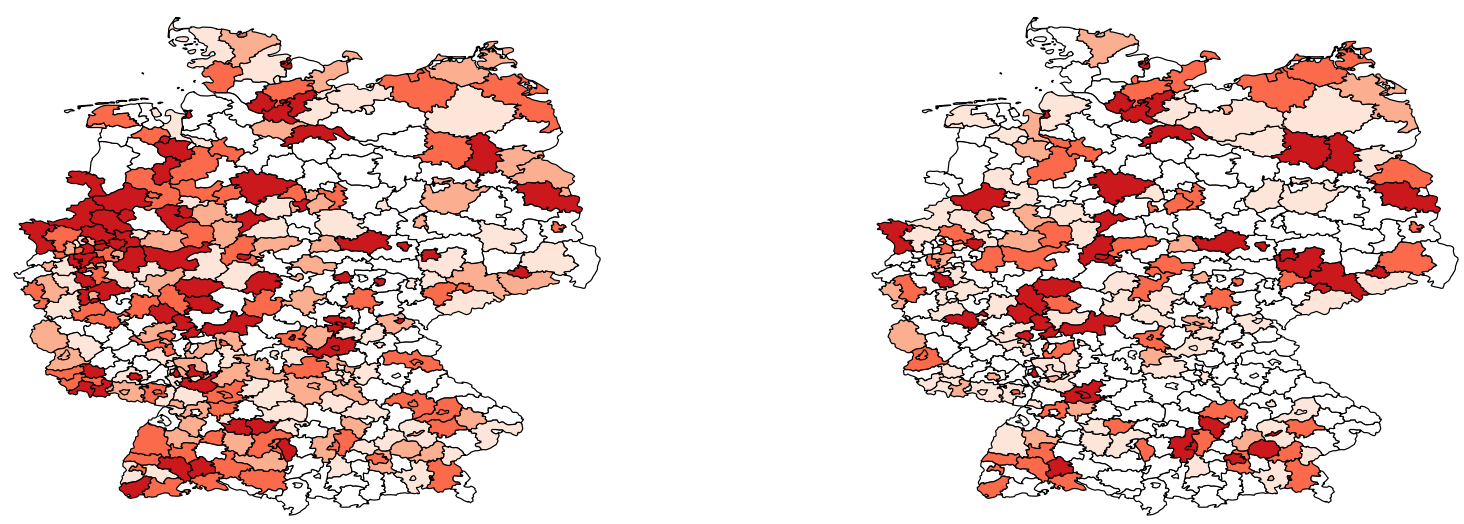

䂅

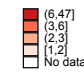

(a) Syrian origin
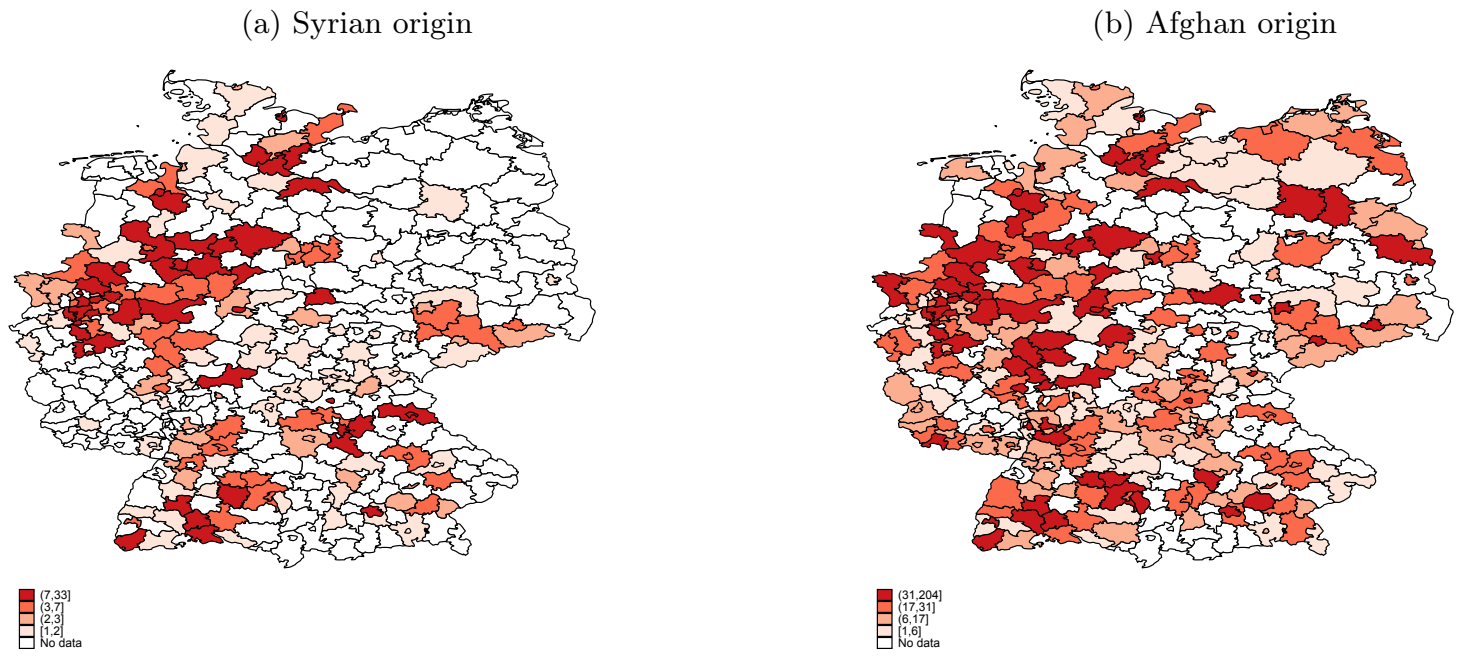

(c) Iraqi origin

(d) All refugees

Note: Figures A1a to A1d display the number of refugees per county, disaggregated by country of origin. Similarly to our main analysis, we pool observations over years to increase the sample size. Source: IAB-BAMF-SOEP Survey of Refugees, v35 (2016-2018) 
Figure A2: Number of refugees per county, disaggregated by country of origin

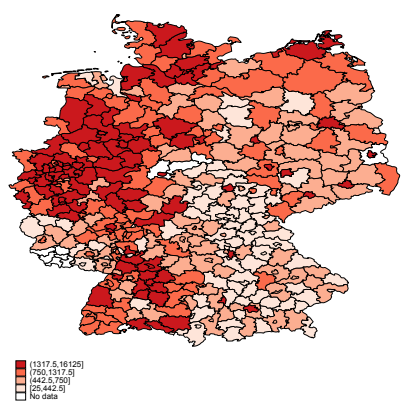

(a) Syrian origin, 2016

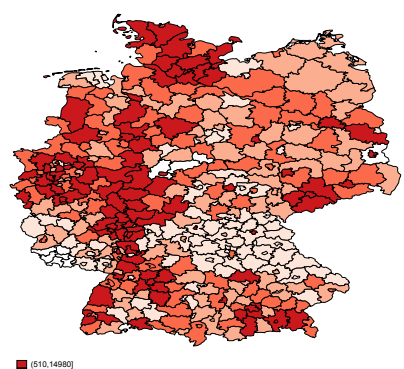

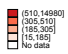

(d) Afghan origin, 2016

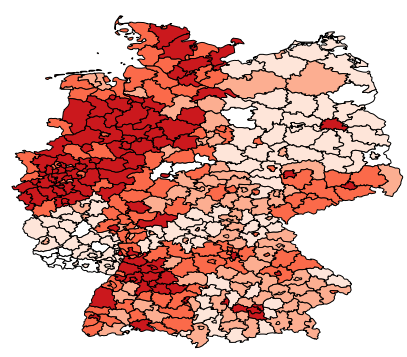

睛

(g) Iraqi origin, 2016

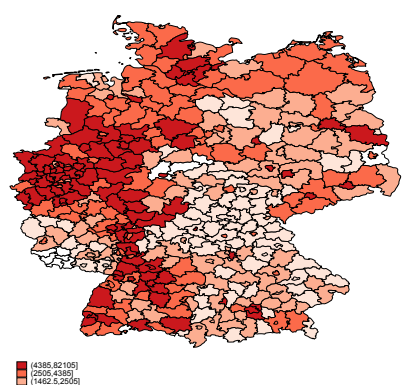

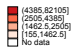

(j) In need of protection, 2016

(k) In need of protection, 2017

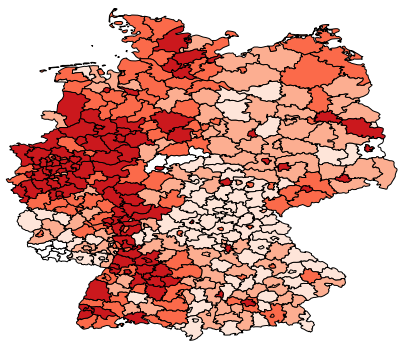

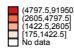

(e) Afghan origin, 2017

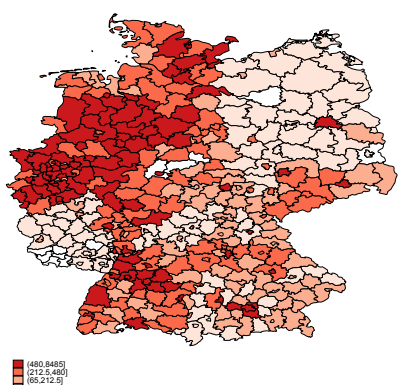

(h) Iraqi origin, 2017

counties do not publish the number of people in protection. These are classified as "No data". Source: Destatis (2016-2018).

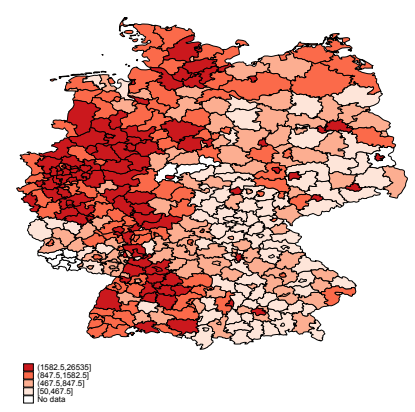

(c) Syrian origin, 2018

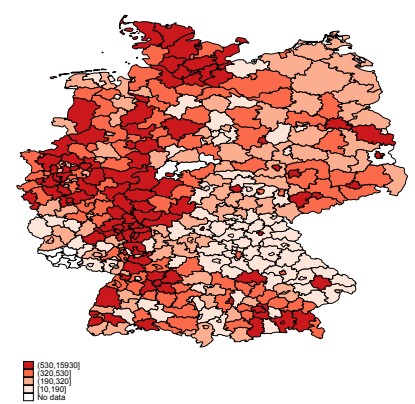

(f) Afghan origin, 2018

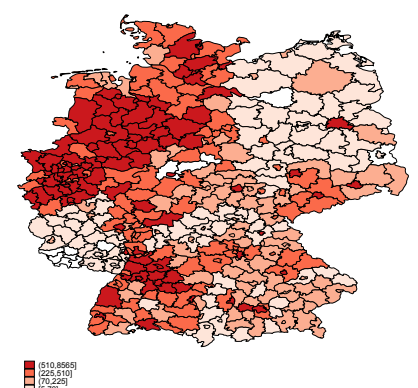

(i) Iraqi origin, 2018

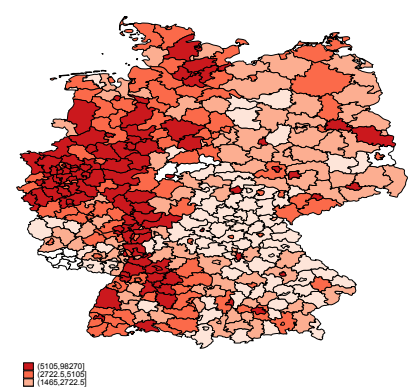

(l) In need of protection, 2018
untry of origin and year. Some me 
Figure A3: County-level unemployment rate, disaggregated by year

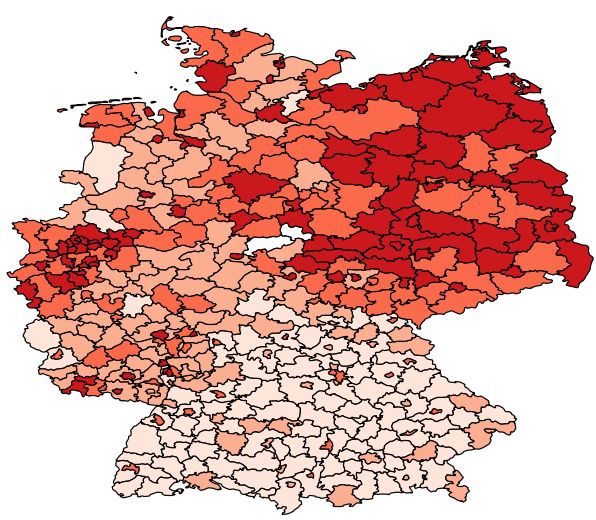

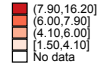

(a) 2016

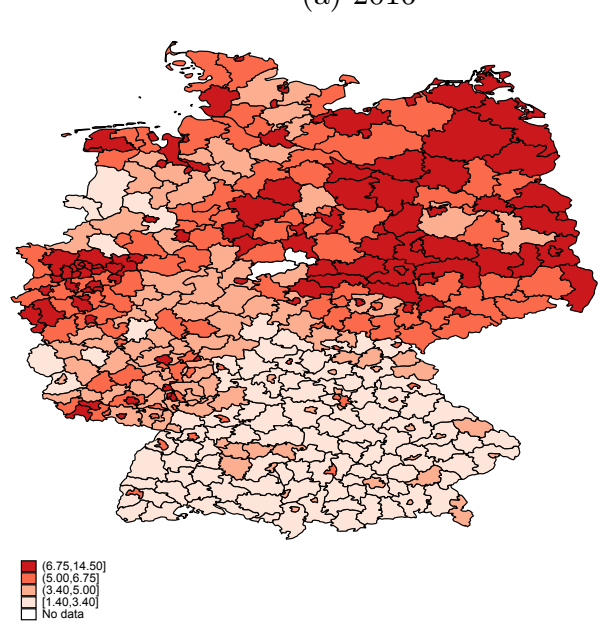

(c) 2018

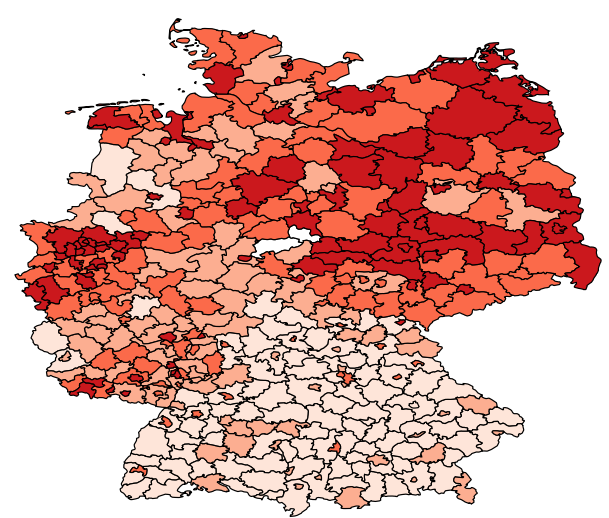

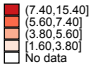

(b) 2017

A3c display the county-level unemployment rate from 2016 to 2018. Source: Destatis (2016-2018). 
Figure A4: Scree plot for principle component analyses of the migrant subscales from the ESS data

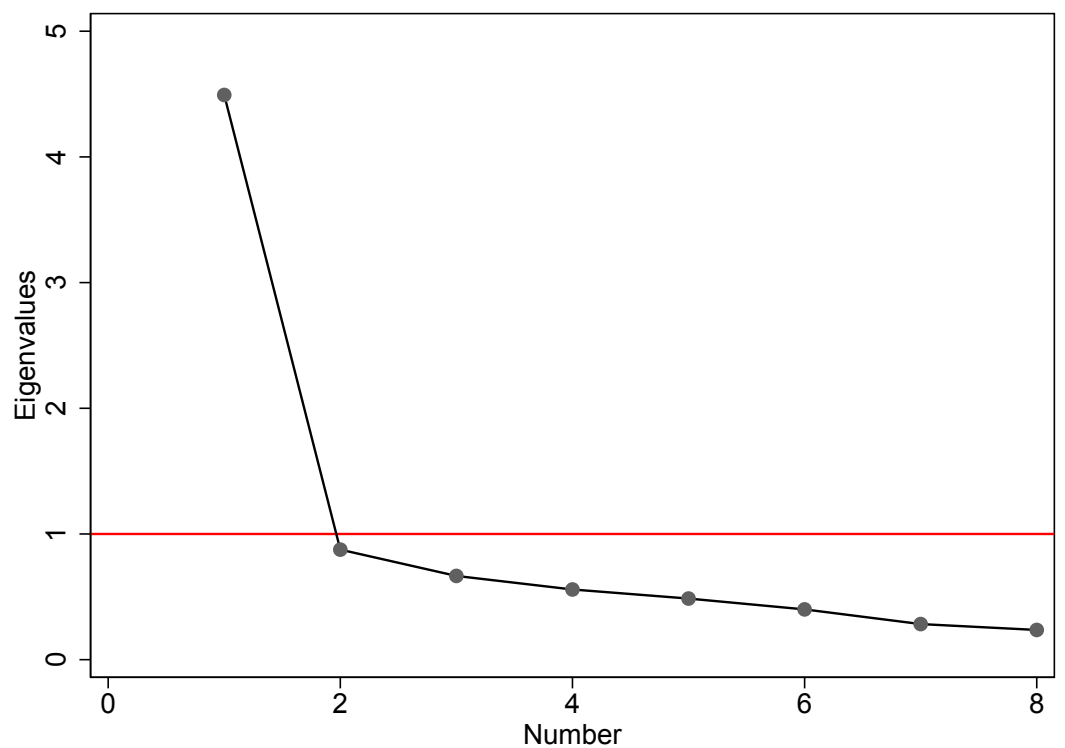

Note: Figure A4 plots the factors and the corresponding eigenvalues after a principle component analysis of the eight migrant subscales, which are used to build the Migrant Acceptance Index. The red horizontal line corresponds to Eigenvalues of one. Figure A4 shows that the first factor (MAI) has the highest predictive power. Source: European Social Survey (2014). 
Figure A5: Correlation of the Migrant Acceptance Index and alternative measures of attitudes towards immigrants

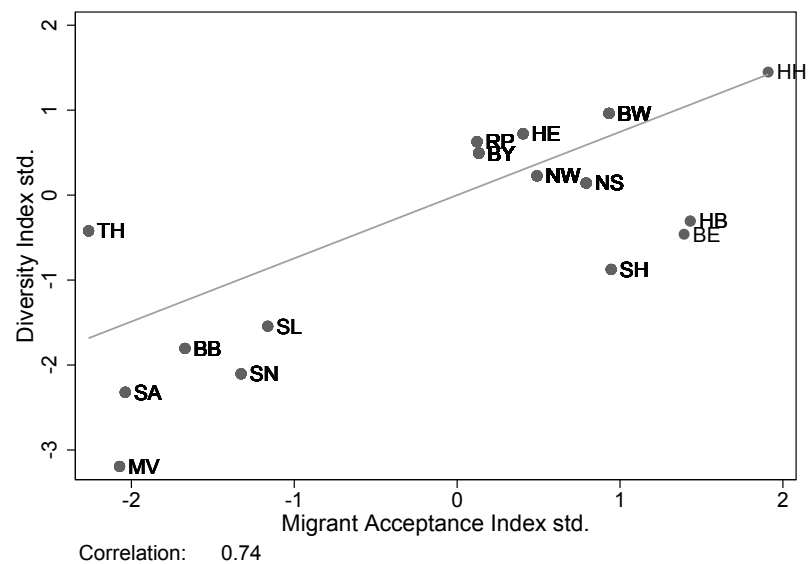

(a) Gallup Diversity Index

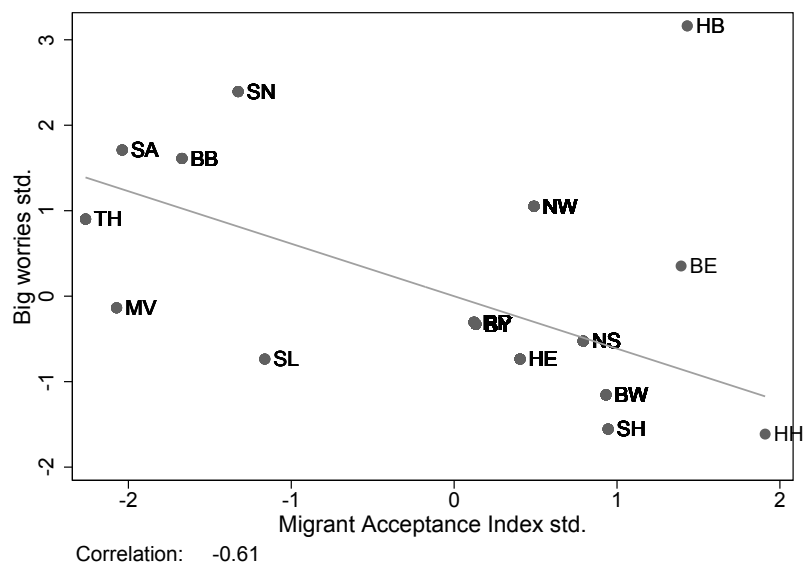

(c) Big worries about immigration

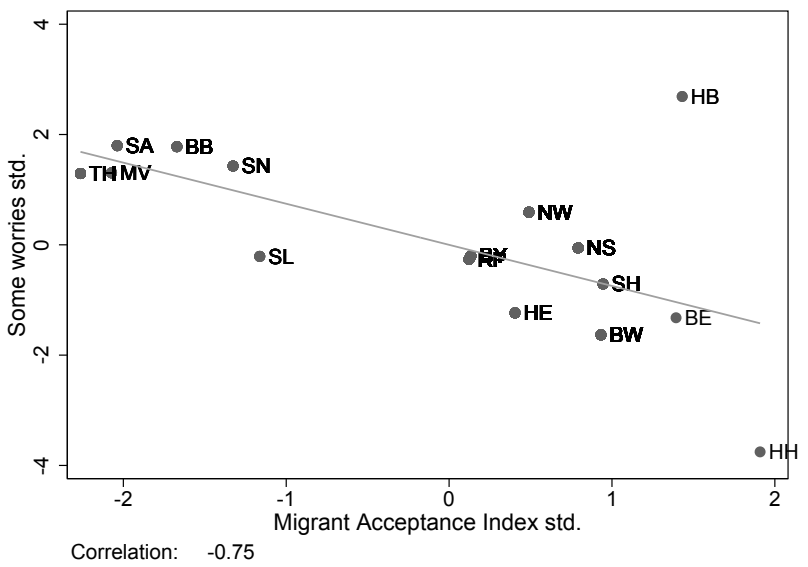

(b) Some worries about immigration

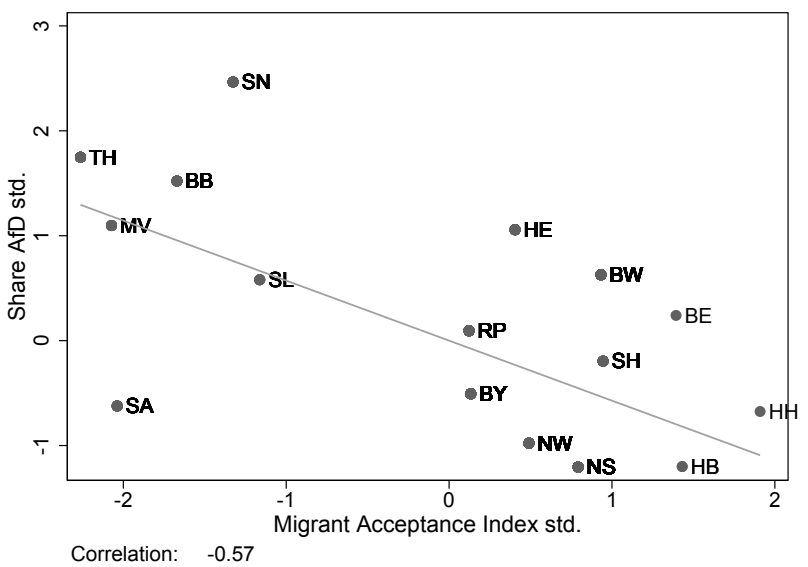

(d) Share of votes to AfD

Note: Figures A5a to A5d display the correlation between the Migrant Acceptance Index and alternative measures of attitudes towards immigration at the state-level. Correlations are based on the Pearson's correlation coefficient. Source: SOEP v35, Gallup World Polls (2014) and European Social Survey (2014). 
Figure A6: Gallup diversity index

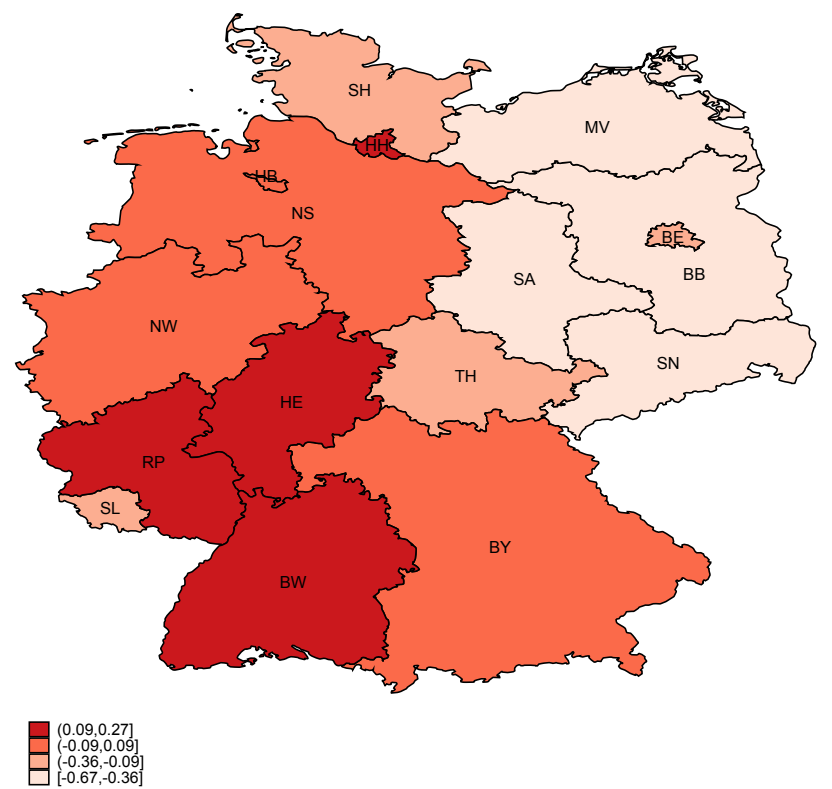

Note: Figure A6 plots the Gallup diversity index at state level. Source: Gallup World Polls (2014). Abbreviations are as follows: SH - Schleswig Holstein; HH - Hamburg; NS - Lower Saxony; HB - Bremen; NW - North Rhine-Westphalia; HE Hessen; RP - Rhineland Palatine; BW - Baden Wurttemberg; BY - Bavaria; SL - Saarland; BE - Berlin; BB - Brandenburg; MV - Mecklenburg-West Pomerania; SN - Saxony; SA - Saxony Anhalt; TH - Thuringia. . 
Figure A7: Histogram of conditional treatment effects

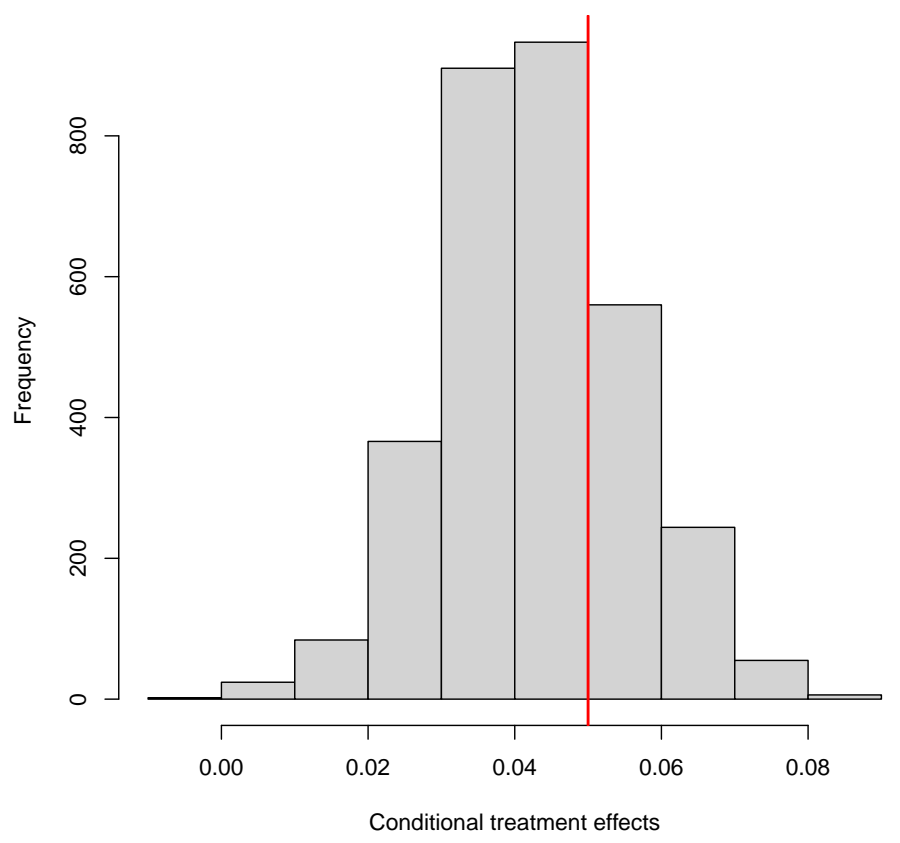

(a) Treatment: Migrant Acceptance Index

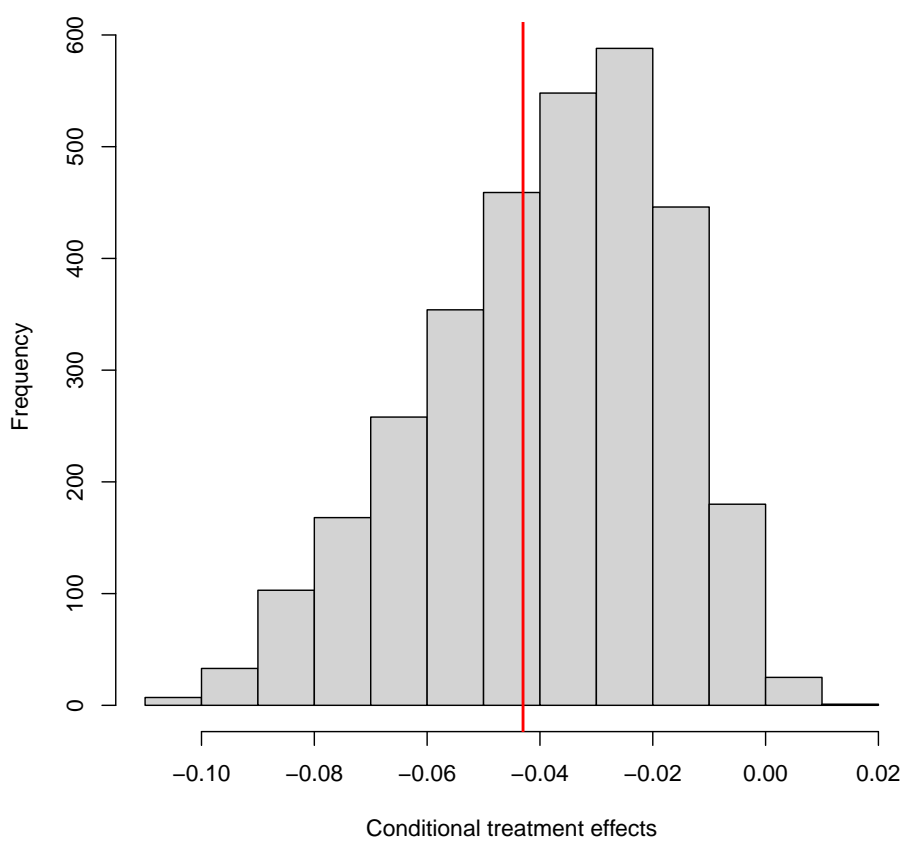

(b) Treatment: Unemployment rate t-2 std.

Note: Figures A7a to A7b display the conditional treatment effects for "being in employment or education" based on generalized random forest estimation ( $\mathrm{N}=20,000$ trees). The red vertical line indicates the level of the treatment effect in the baseline model. Source: SOEP v35 and European Social Survey (2014). 
Figure A8: Variable Importance

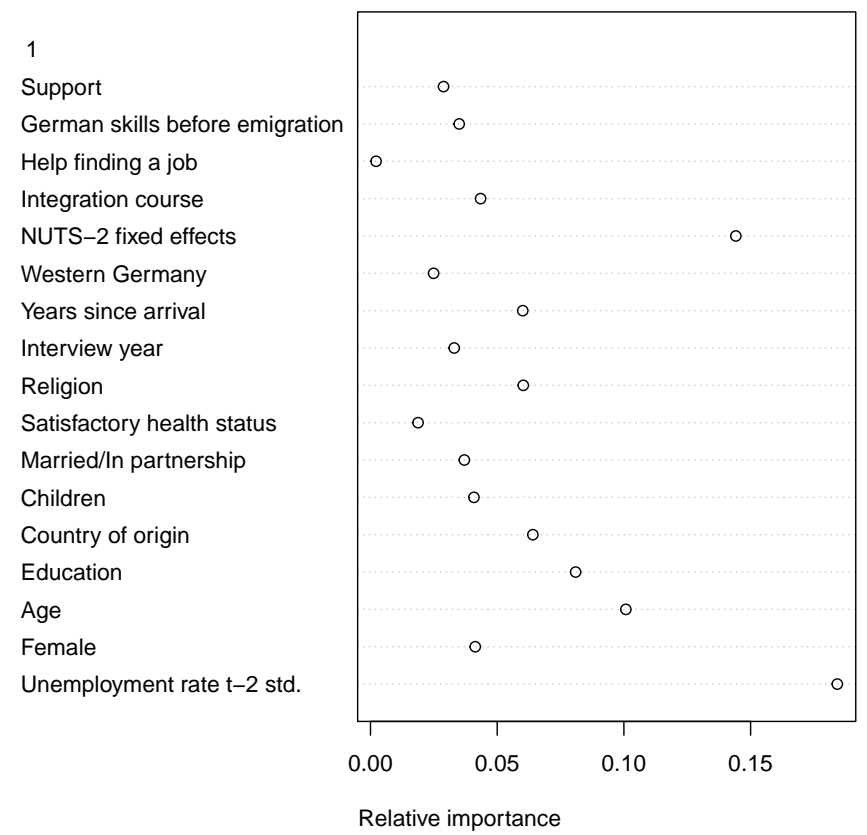

(a) Treatment: Migrant Acceptance Index

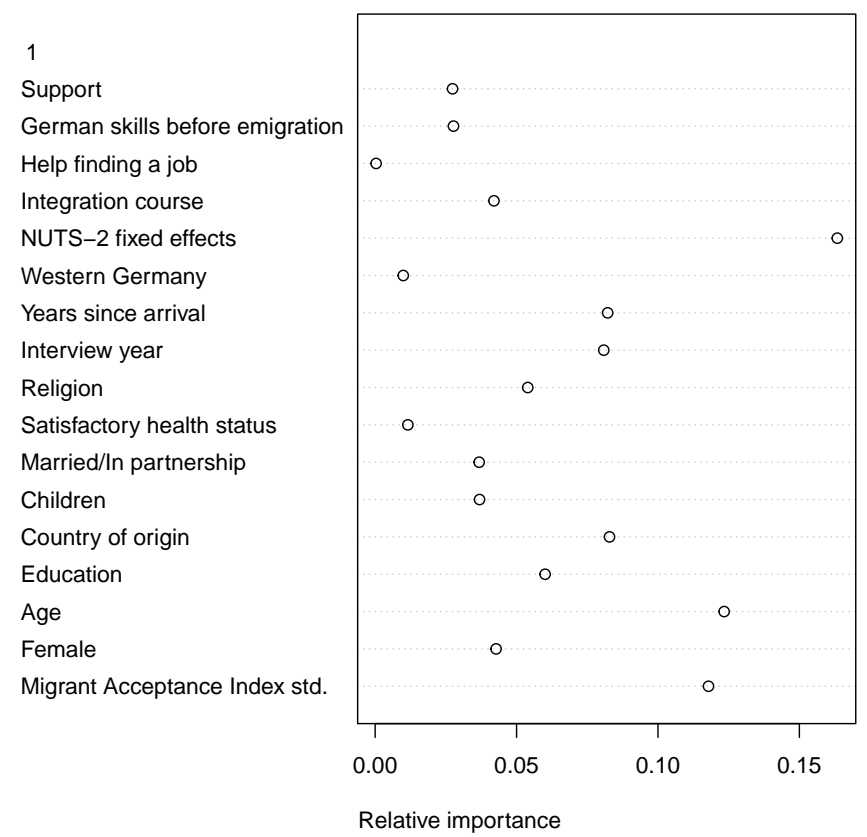

(b) Treatment: Unemployment rate t-2 std.

Note: Figures A8a to A8b illustrate the variable importance for "being in employment or education" in a generalized random forest framework $(\mathrm{N}=20,000$ trees). The variable importance plot provides a simple weighted sum of how many times a feature was split at each depth in the forest. Source: SOEP v35 and European Social Survey (2014). 
Figure A9: Robustness of alternative lags of unemployment

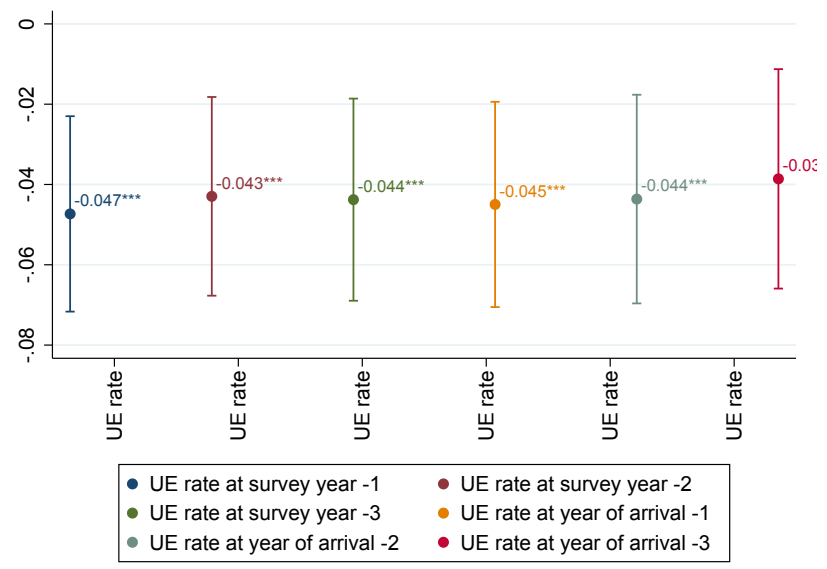

(a) In employment or education

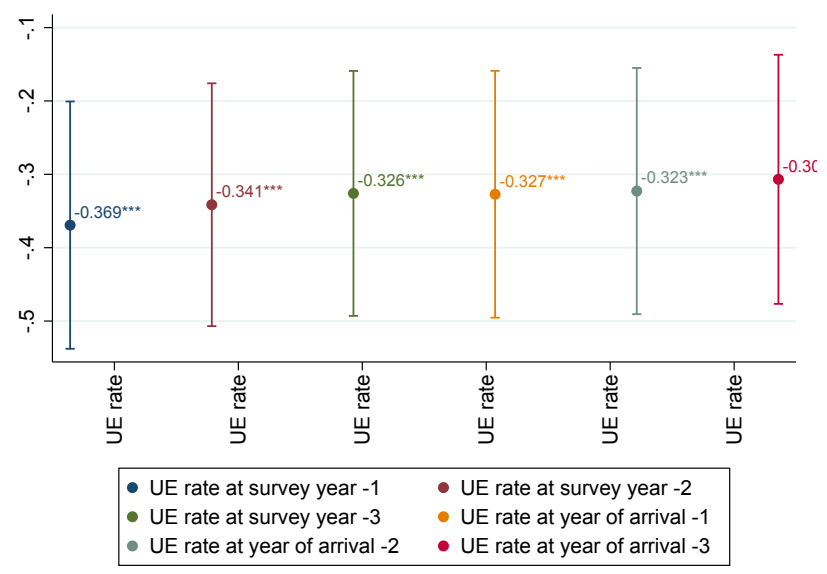

(c) Net monthly wages

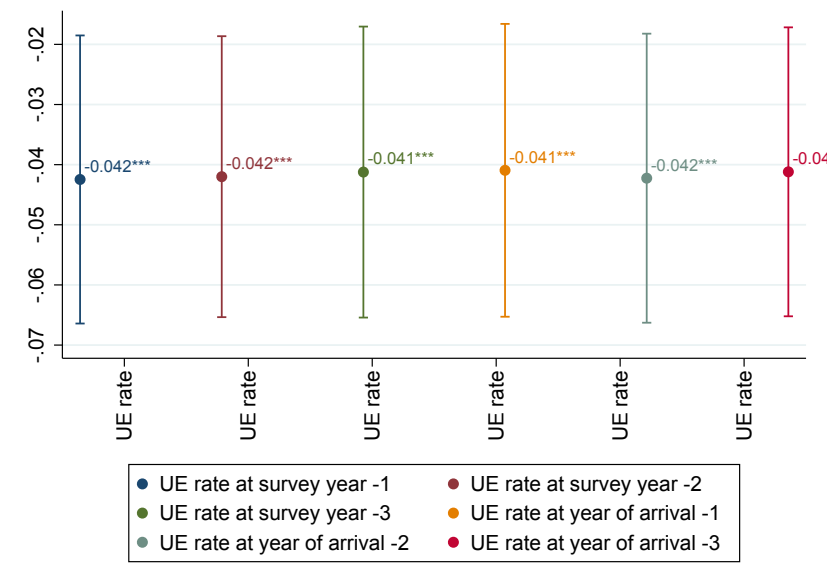

(b) Full or part-time employment

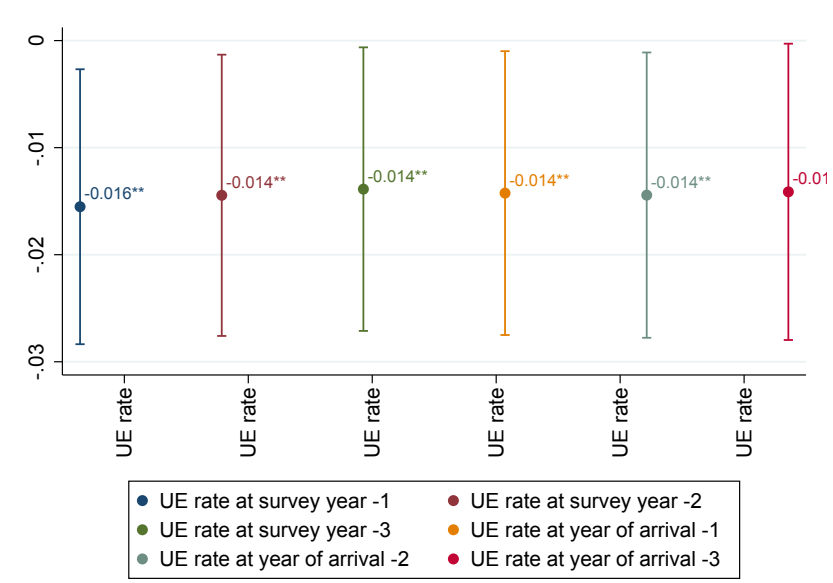

(d) Multi-dimensional Integration Index

Note: Figures A9a to A9d display the robustness of our estimation results to alternative lags of unemployment. Source: SOEP v35 and European Social Survey (2014). 
Figure A10: Robustness to using alternative measures of attitudes towards immigrants at the county level

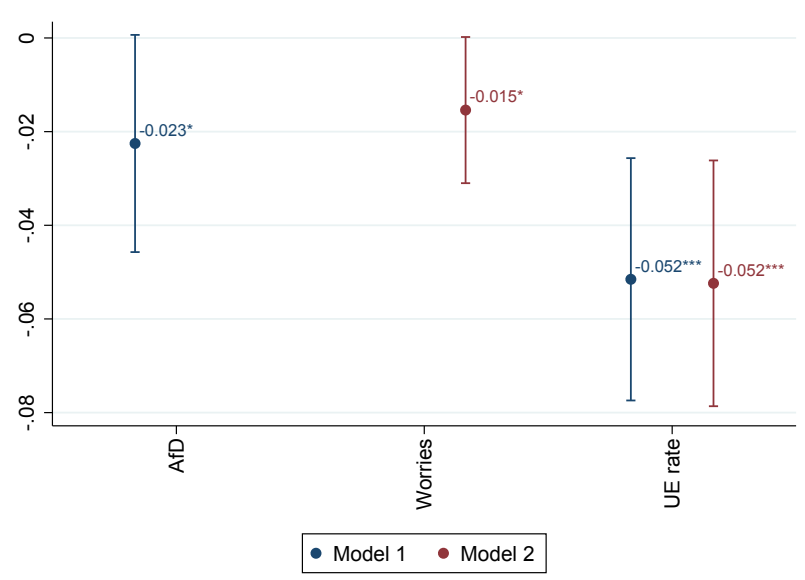

(a) In employment or education

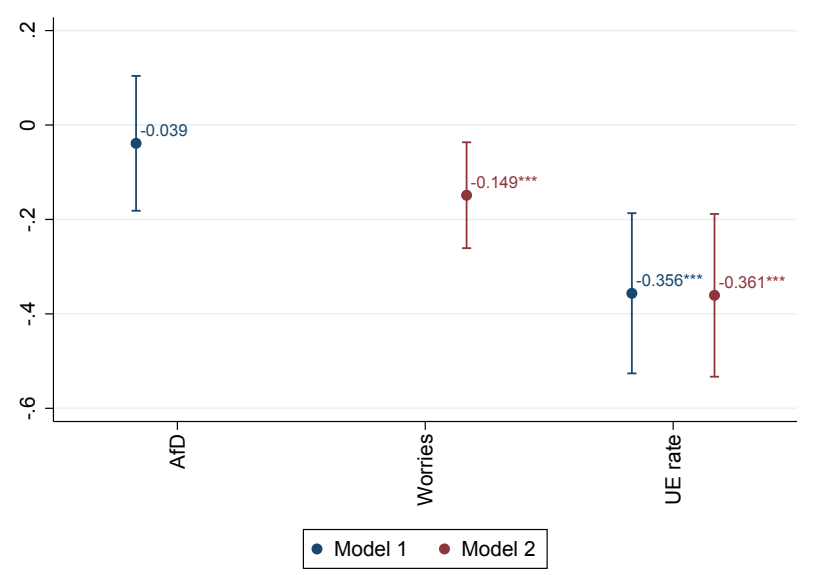

(c) Net monthly wages

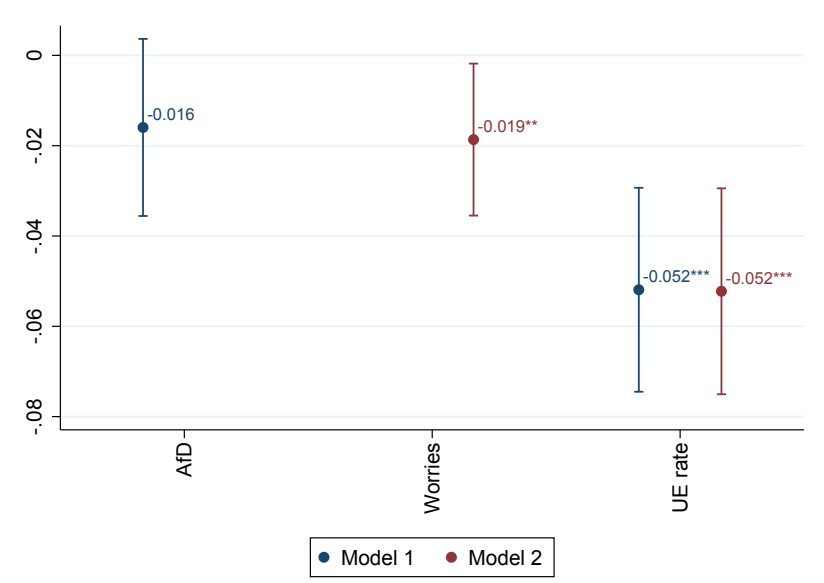

(b) Full or part-time employment

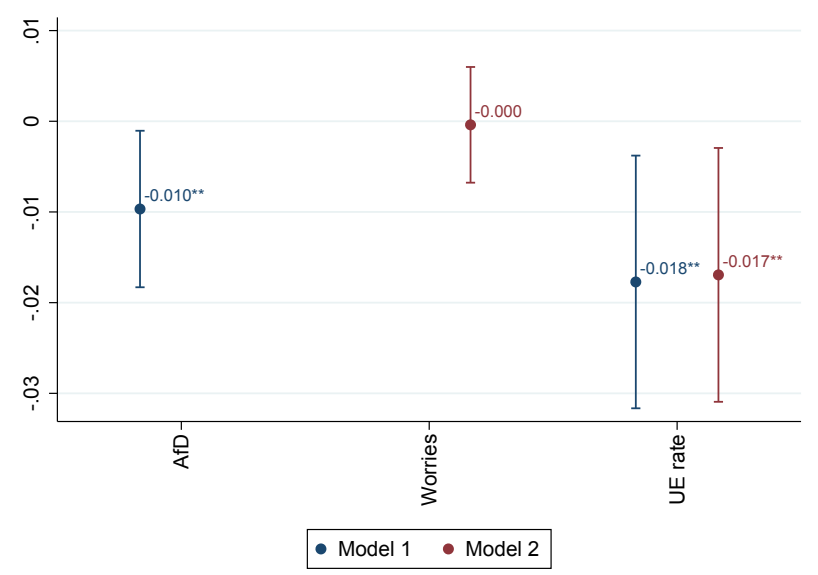

(d) Multi-dimensional Integration Index

Note: Figures A10a to A10d display the robustness of our estimation results to alternative measures of attitudes towards immigrants at the county level. Source: SOEP v35 and European Social Survey (2014). 